\title{
Estudo Morfológico Ultraestrutural e I muno-Histoquímico da I nfluência do Excesso de Flúor no Desenvolvimento do Germe Dental de I ncisivo de Rato
}

\section{RENATO MASSAHARU HASSUNUMA}

Tese apresentada à Faculdade de Odontologia de Bauru, da Universidade de São Paulo, como parte dos requisitos para obtenção do grau de DOUTOR em Odontologia, área de Biologia Oral.

(Edição Revisada) 


\section{Estudo Morfológico Ultraestrutural e I muno-Histoquímico da I nfluência do Excesso de Flúor no Desenvolvimento do Germe Dental de I ncisivo de Rato}

\section{RENATO MASSAHARU HASSUNUMA}

Tese apresentada à Faculdade de Odontologia de Bauru, da Universidade de São Paulo, como parte dos requisitos para obtenção do grau de DOUTOR em Odontologia, área de Biologia Oral.

(Edição Revisada)

Orientador:

Prof. Dr. Gerson Francisco de Assis 

histoquímico da influência do excesso de flúor no desenvolvimento do germe dental de incisivo de rato. / Renato Massaharu Hassunuma - Bauru, 2006.

199p.: il.; $30 \mathrm{~cm}$

Tese. (Doutorado) - Faculdade de Odontologia de Bauru. USP.

Orientador: Prof. Dr. Gerson Francisco de Assis

Autorizo, exclusivamente para fins acadêmicos e científicos a reprodução total ou parcial desta tese, por processos fotocopiadores e/ou meio eletrônico.

Assinatura do autor:

Data:

Comitê de Ética no Ensino e Pesquisa em Animais da FOB: Projeto de pesquisa aprovado em 05 de Maio de 2004

Número do protocolo: 09/2004 


\section{DADOS CURRICULARES}

RENATO MASSAHARU HASSUNUMA

22 de Setembro de 1973

1991 - 1994

$1^{\circ}$ semestre de 1995

$2^{\circ}$ semestre de 1995 - 1998

$2^{\circ}$ semestre de $1998-2003$

$2^{\circ}$ semestre de 1998 - 2003

1999
Nascimento

Bauru - SP

Curso de Graduação em Odontologia, na Faculdade de Odontologia de Bauru, na Universidade de São Paulo.

Estágio voluntário junto ao setor de Prótese no Hospital de Pesquisa e Reabilitação de Lesões LábioPalatais, na Universidade de São Paulo.

Curso de Pós-graduação em Patologia Bucal, em nível de Mestrado, na Faculdade de Odontologia de Bauru, na Universidade de São Paulo.

Professor Adjunto I das Disciplinas de Biologia I e II, Citologia, Embriologia e Histologia I e II dos Cursos de Odontologia, na Universidade Paulista (UNIP Objetivo).

Professor Adjunto I das Disciplinas de Citologia, Embriologia e Histologia I e II dos Cursos de Farmácia e Bioquímica na Universidade Paulista (UNIP - Objetivo)

Professor Adjunto I da Disciplina de Microbiologia, Imunologia e Parasitologia I e II do Curso de Odontologia e Farmácia e Bioquímica na Universidade Paulista (UNIP - Objetivo).

Professor Adjunto I da Disciplina de Diagnóstico Bucal I e II do Curso de Odontologia na Universidade Paulista (UNIP - Objetivo). 

Bucal I e II do Curso de Odontologia na Universidade Paulista (UNIP - Objetivo).

1999 - atual

2002 - 2004

2002 - 2004

2004

2005

2006-atual

2006-atual

2006-atual

Associações
Professor Adjunto I da Disciplina de Patologia I e II Processos Gerais do Curso de Farmácia e Bioquímica na Universidade Paulista (UNIP - Objetivo).

Professor Adjunto I das Disciplinas de Fundamentos de Biologia I e II do Curso de Enfermagem na Universidade Paulista (UNIP - Objetivo).

Professor Adjunto I das Disciplinas de Fundamentos de Biologia e Fundamentos Biológicos aplicados à Educação Física do Curso de Educação Física na Universidade Paulista (UNIP - Objetivo).

Professor Adjunto I da Disciplina de Histomorfologia do Curso de Farmácia e Bioquímica na Universidade Paulista (UNIP - Objetivo).

Professor Adjunto I da Disciplina de Histologia e Embriologia (Genética) dos Cursos de Enfermagem, Farmácia e Bioquímica e Fisioterapia na Universidade Paulista (UNIP - Objetivo).

Professor Adjunto I da Disciplina de Patologia do Curso de Farmácia e Bioquímica na Universidade Paulista (UNIP - Objetivo).

Professor Adjunto I da Disciplina de Patologia do Curso de Fisioterapia na Universidade Paulista (UNIP - Objetivo).

Professor Adjunto I da Disciplina de Patologia do Curso de Enfermagem na Universidade Paulista (UNIP - Objetivo).

Conselho Federal e Regional de Odontologia 
“ - Ainda por aqui, Laertes? - diz Polônio, entrando na sala. - Que vergonha, já para bordo! O vento está soprando as velas do seu navio, e só falta você embarcar. Vá com a minha benção continua, pondo a mão sobre a cabeça de Laertes - e leve estes conselhos gravados na memória. Não diga nem faça nada antes de pensar. Seja amistoso sem ser vulgar. Prenda os amigos de verdade à sua alma com ganchos de aço, mas não faça calos na mão cumprimentando e abraçando qualquer um que apareça. Nunca entre em brigas, mas se entrar, faça o adversário ficar com medo de você. Escute todo mundo, mas fale com poucos. Leve sempre em consideração as críticas dos outros, mas não julgue ninguém. Compre só as roupas que possa pagar, sem se preocupar em seguir a moda. Pode-se ser rico sem ostentação: a roupa já mostra quem é a pessoa. Na França, as pessoas de melhor condição dão o melhor exemplo disso. Não empreste nem peça emprestado, pois quando se empresta em geral se perde o amigo e o que se emprestou, e quando se toma emprestado se perde a noção certa do que é economia. E, acima de tudo, o seguinte, a saber: seja verdadeiro com você mesmo; a conseqüência disso (assim como a noite e o dia vêm um depois do outro) é que você não será falso com ninguém. Adeus! Que a minha benção faça todos esses bons propósitos crescerem dentro de você!"”

(Hamlet, William Shakespeare) 
(Verso da folha comum) 
Aos meus pais, Eiso Hassunuma e Mary Hitomi Hassunuma, por todo apoio e dedicação em todos os momentos de minha vida.

À minha irmã Cristina Yuka Hassunuma e meu cunhado Leonardo Oshiro por seus exemplos de força, coragem, companheirismo e amor.

Ao Professor Doutor Gerson Francisco de Assis por todos estes anos de colaboração e dedicação, desde a Graduação em Odontologia, durante o Mestrado em Patologia Bucal até a conclusão do Doutorado em Biologia Oral. Obrigado por acreditar em meu potencial e, especialmente, por seu exemplo de humanidade, humildade e altruísmo.

Meu Agradecimento (mais que) Especial. 
(Verso da folha comum) 


\section{AGRADECIMENTOS}

É um prazer muito grande fazer parte da primeira Turma de Doutorado do Programa de Biologia Oral, o qual faz parte do Curso de Pós-Graduação de Estomatologia. Sendo assim, primeiramente devo agradecer o Diretor da Faculdade de Odontologia de Bauru (USP) Prof. Dr. Luiz Fernando Pegoraro, o Presidente da Comissão de Pós-Graduação Prof. Dr. José Carlos Pereira, a Coordenadora do Programa de Pós-Graduação em Estomatologia Profa. Dra. Ana Lúcia Álvares Capelozza e o Prof. Dr. Antonio de Castro Rodrigues, Coordenador do Curso de PósGraduação em Biologia Oral. Sem esquecer de agradecer aos professores que assumiam estes cargos no momento da minha entrada no curso: a Profa. Dra. Maria Fidela de Lima Navarro (Direção da FOB-USP), o Prof. Dr. José Humberto Damante (Coordenação do Curso de Estomatologia) e o Prof. Dr. José Mauro Granjeiro (Coordenação do Curso de Biologia Oral).

Em março de 2004, quando foi aberta a inscrição para o Doutorado em Biologia Oral, fui muito bem acolhido pelo Professor Doutor Gerson Francisco de Assis, o qual prontamente me adotou como orientado. Aliás, como já havia feito antes durante o mestrado. Por um lapso meu, o Dr. Gerson não recebeu na época os merecidos créditos de co-orientador da minha tese de mestrado. Mas hoje, através destas palavras, agradeço novamente por toda força e ensinamentos recebidos em minha vida acadêmica. Aliás, antes disso... na verdade desde julho 1991, quando foi meu orientador num estágio que realizei em meu primeiro ano de graduação no Laboratório de Histologia. Posso dizer com certeza que o Professor Gerson e o Professor Doutor Rumio Taga são hoje os principais responsáveis pela minha formação acadêmica.

Durante estes já 15 anos de convivência no Laboratório de Histologia ganhei a amizade de muitas "celebridades" das ciências morfológicas como os Professores Doutores Antonio Carlos Marconi Stipp, Dagoberto Sottovia Filho e mais recentemente o Professor Doutor Gustavo Pompermayer Garlet. Em todos estes anos também pude contar com a força e a amizade das funcionárias Beonildes Teresinha Ruiz Correia e Aldivina da Silva Michelotto, que sempre me apoiaram durante toda minha estada no Departamento.

Ainda me lembro como se fosse hoje, quando eu e minha turma de doutorado alugamos uma "van" para prestar o exame do "Toefl” em São Paulo: Ana Eliza Akashi, Esther Rieko Takamori, Flávia Mauad Levy, Maria Heloísa Correa Rodrigues, Sílvia Helena de Carvalho Sales Peres, Tania Mary Cestari e eu! Todos "desesperados" para saber o resultado da prova! Ainda bem que tudo deu certo! A nós se juntaram Ariadne Machado Gonçalves Letra e Cláudia Barbosa Quintella para completar o time! Foi muito corrido estudar várias disciplinas básicas para 
a prova de seleção, mas por sorte contei com a ajuda da Técnica Telma Lopes Silva para esclarecer várias dúvidas em relação à bioquímica.

E então o Doutorado começou. Durante o cumprimento das disciplinas, eu pude ter a oportunidade de conhecer muitas pessoas, entre elas a Profa. Dra. Marília Afonso Rabelo Buzalaf. Já nos conhecíamos do tempo de ginásio, no Colégio Prevê-Objetivo em Bauru, e depois voltamos a nos encontrar na FOB-USP. Desde jovem a Profa. Marília já demonstrava uma inteligência muito acima da média! E pude comprovar durante meu curso que sua fama faz jus a toda sua capacidade intelectual. Aprendi muito... não apenas em conhecimento, mas também pelo seu exemplo de humildade e educação.

Cerca de um mês antes da prova de seleção para Doutorado, após várias reuniões com o Dr. Gerson, decidimos que o tema da minha tese seria a continuação de uma linha de pesquisa já em andamento. Por isso não posso deixar de agradecer a todos que abriram esta linha de pesquisa e que deixaram um legado para eu pudesse continuar: a Doutora Maria Renata Sales Nogueira Costa e o Professor Doutor Daniel Araki Ribeiro (por suas Teses de Mestrado) e Alexandre Yunomae e Marcelo Matida Hamata (por seus projetos de iniciação científica).

Após a aprovação na seleção de Doutorado, comecei a me dedicar à parte prática da Tese. Embora tenha usado parte do material coletado pelo Alexandre e pelo Marcelo, fizemos alguns pilotos para testar a reação imuno-histoquímica para amelogenina e outros tipos de fixadores. Para isso, contamos com a colaboração do Coordenador do Biotério Luiz Carlos Silva para planejar a utilização dos animais e orientar sobre o comportamento alimentar e o desenvolvimento dentário dos animais utilizados. Aprendi com o Luiz que os animais que utilizamos em pesquisa não são apenas "cobaias", mas são seres vivos que têm comportamentos que podem influenciar nos resultados da pesquisa. E só quem convive e cuida destes animais é que pode nos ajudar a descobrir quais são estes comportamentos!

Depois partimos para os cortes histológicos para microscopia óptica. Para isso contei com a Técnica Danielle Santi Ceolin. Embora eu tenha experimentado realizar alguns cortes, somente a Danielle (e ninguém mais!) seria capaz de realizá-los tão bem. Somente uma pessoa com tanta habilidade poderia conseguir cortes histológicos transversais de um incisivo com cerca de um milímetro..

Em seguida veio a execução da reação imuno-histoquímica para amelogenina. Nesta fase, contei mais uma vez com a ajuda da Tania que me demonstrou o protocolo de execução. Contei também com o auxílio do aluno de graduação Edson Virgílio Zen Filho. Foram dias e dias padronizando a reação até que se chegasse no resultado final. Mas valeu a pena...

Então foi a vez da Microscopia Eletrônica de Transmissão. Contamos com a ajuda do Professor Doutor Elliot Watanabe Kitajima que nos abriu as portas do Laboratório de Microscopia da Escola Superior de Agricultura "Luiz de Queiroz" para que as amostras fossem analisadas. Nestas várias idas e vindas a Piracicaba pude contar mais uma vez com a ajuda do Professor Dr. Gerson (o qual acompanhou diretamente o exame de todas amostras analisadas), da 
Tânia e da Danielle, além dos alunos de graduação da UNESP - Bauru: Bruno Alvares Viscelli e Juliana Gonçalves de Oliveira.

No final de meu doutoramento, contei com a ajuda da Bibliotecária Valéria Cristina Trindade Ferraz para relembrar todas as normas para publicação da Tese. Não posso esquecer de agradecer "a mais do que essencial" Secretária do Curso de Biologia Oral Vera Lúcia Rosa Rufino que ajudou a mim e a todos os meus colegas em vários momentos de nosso curso.

E não foi apenas na FOB-USP que tive ajuda de amigos. Sou muito grato a todos amigos, coordenadores, professores e funcionários da UNIP-Objetivo. Sou muito grato especialmente às amigas Márcia Heloísa R. Conti Silveira, Mara Regina Silva e Thaís Maria Vieira, que me apóiam desde minha entrada na UNIP em 1997. E também aos amigos do Instituto de Arte Contemporânea (IAC-Bauru), especialmente Edu Toledo e Sandra Regina Rodrigues por todo apoio, compreensão e confiança. Obrigado, por realmente acreditarem em meu potencial.

Tenho que agradecer também à irmã de coração que eu ganhei no Curso de Doutorado em Biologia Oral Esther Rieko Takamori por confiar sempre em mim e sua amizade. Obrigado pelo apoio, dedicação e principalmente pelo exemplo de altruísmo em prestar a sua ajuda de forma tão incondicional a todas pessoas que a cercam.

Agradeço também a FAPESP por meio de auxílio à pesquisa dos processos FAPESP no 02/13984-4, 03/06082-7 e 04/07854-6 (todos orientados pelo professor doutor Gerson Francisco de Assis), cujos recursos materiais puderam também ser aproveitados no desenvolvimento da atual pesquisa.

Meus Sinceros Agradecimentos a Todos. 
(Verso da folha comum) 


\section{SUMÁRIO}

RESUMO

xxiti

1 Introdução

1

2 Revisão de literatura

2.1 A passagem do flúor pela placenta

2.20 flúor presente no leite materno

2.3 Os efeitos do flúor sobre o esmalte dentário

2.4 Os efeitos do flúor sobre os ameloblastos

2.4.1 Alterações morfológicas em ameloblastos causadas pelo flúor

2.4.2 Alterações na modulação de ameloblastos causadas pelo flúor

3 Proposição

4.1 Tratamento e obtenção dos animais

4.2 Eutanásia dos animais, coleta e fixação das hemimandíbulas

4.2.1 Fixação para o estudo em microscopia óptica e análise imuno-histoquímica

4.2.2 Fixação para o estudo em microscopia eletrônica

4.2.3 Desmineralização

4.3 Procedimento laboratorial e metodologia para microscopia óptica

4.3.1 Análise morfológica pela coloração de hematoxilina e eosina

4.3.2 Tratamento imuno-histoquímico para amelogenina

4.4 Procedimento laboratorial e metodologia para microscopia eletrônica de transmissão

4.5 Análises morfométricas e estatísticas

4.5.1 Avaliação do comprimento da matriz de esmalte 
4.5.4 Avaliação da densidade de volume nuclear e citoplasmático 62

4.5.5 Avaliação do volume citoplasmático absoluto 63

4.5.6 Análise estatística 63

$\begin{array}{ll}5.1 \text { Resultados morfológicos } & 67\end{array}$

5.1.1 Descrição morfológica macroscópica $\quad 67$

5.1.2 Descrição morfológica microscópica $\quad 69$

5.1.2.1 Grupo I: animais recém-nascidos $\quad 69$

5.1.2.2 Grupo II: animais com sete dias de vida pós-natal 77

5.1.2.3 Grupo III: animais com 14 dias de vida pós-natal $\quad 87$

5.1.3 Descrição morfológica da microscopia eletrônica 93

5.1.3.1 Grupo I: animais recém-nascidos 93

5.1.3.1.1 Descrição do ameloblasto do subgrupo controle 93

5.1.3.1.2 Descrição do ameloblasto do subgrupo de 7ppm 94

5.1.3.1.3 Descrição do ameloblasto do subgrupo de 100ppm 94

5.1.3.2 Grupo II: animais com sete dias de vida pós-natal 103

5.1.3.2.1 Descrição do ameloblasto do subgrupo controle 103

5.1.3.2.2 Descrição do ameloblasto do subgrupo de 7ppm 103

5.1.3.2.3 Descrição do ameloblasto do subgrupo de 100ppm 104

5.1.3.3 Grupo III: animais com 14 dias de vida pós-natal $\quad 115$

5.1.3.3.1 Descrição do ameloblasto do subgrupo controle $\quad 115$

5.1.3.3.2 Descrição do ameloblasto do subgrupo de 7ppm 115

5.1.3.3.3 Descrição do ameloblasto do subgrupo de 100ppm 116

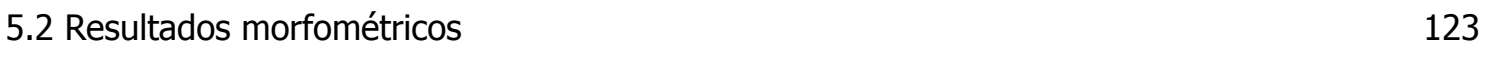

5.2.1 Comprimento da matriz de esmalte 123

$\begin{array}{ll}\text { 5.2.2 Altura e volume dos ameloblastos } & 125\end{array}$

6.1 Considerações sobre os resultados obtidos na análise morfológica em microscopia óptica e análise imuno-histoquímica para amelogenina

6.2 Considerações sobre os resultados obtidos na análise morfológica em microscopia eletrônica 


\section{Anexos}

Anexo 1 Protocolo para preparo da solução fixadora de paraformaldeído

Anexo 2 Protocolo para preparo da solução fixadora de EDTA

Anexo 3 Protocolo para preparo dos corantes utilizados na técnica de hematoxilina e eosina 160

Anexo 4 Protocolo para coloração de hematoxilina e eosina

Anexo 5 Protocolo para o tratamento imuno-histoquímico da amelogenina

Anexo 6 Protocolo para o processamento e inclusão dos fragmentos histológicos em resina

Spurr

Anexo 7 Protocolo para solução aquosa de azul de metileno a 1\% e azur II a $1 \%$ 
(verso da folha comum) 
FIGURA 1 Distribuição dos animais nos grupos experimentais 55

FIGURA 2 Visão macroscópica de rato recém-nascido do subgrupo controle $\quad 67$

FIGURA 3 Montagem de cortes histológicos de germe de incisivo de rato 71 recém-nascido do subgrupo controle para visão panorâmica

FI GURA 4 Cortes histológicos de germe de incisivo de rato recém-nascido do subgrupo controle

FI GURA 5 Cortes histológicos de germe de incisivo de rato recém-nascido do subgrupo controle

FI GURA 6 Cortes histológicos de germe de incisivo de rato recém-nascido do subgrupo controle

FI GURA 7 Cortes histológicos de germe de incisivo de rato recém-nascido do subgrupo de 100ppm

FI GURA 8 Cortes histológicos de germe de incisivo de rato com sete dias de vida pós-natal do subgrupo controle

FIGURA 9 Cortes histológicos de germe de incisivo de rato com sete dias de vida pós-natal dos subgrupos controle, de 7 e de 100ppm

FI GURA 10 Cortes histológicos de germe de incisivo de rato com sete dias de vida pós-natal do subgrupo de sete ppm

FIGURA 11 Cortes histológicos de germe de incisivo de rato com 14 dias de vida pós-natal do subgrupo controle

FI GURA 12 Cortes histológicos de germe de incisivo de rato com 14 dias de vida pós-natal dos subgrupos controle e de sete ppm

FIGURA 13 Cortes histológicos da fase de maturação do germe de incisivo de rato com 14 dias de vida pós-natal dos subgrupos controle e de $100 \mathrm{ppm}$

FI GURA 14 Corte ultrafino de ameloblasto secretor de rato recém-nascido do subgrupo controle

FIGURA 15 Corte ultrafino de ameloblasto secretor de rato recém-nascido do subgrupo de 100ppm

FI GURA 16 Corte ultrafino de ameloblasto secretor de rato com sete dias de vida pós-natal do subgrupo controle 
FIGURA 17 Corte ultrafino de ameloblasto na fase de maturação com borda lisa de rato com sete dias de vida pós-natal do subgrupo controle

FIGURA 18 Corte ultrafino de ameloblasto secretor de rato com sete dias de 109 vida pós-natal do subgrupo de sete ppm

FIGURA 19 Corte ultrafino de ameloblasto secretor de rato com sete dias de vida pós-natal do subgrupo de 100ppm

FIGURA 20 Corte ultrafino de ameloblasto na fase de maturação com borda lisa de rato com sete dias de vida pós-natal do subgrupo de 100ppm

FIGURA 21 Corte ultrafino de ameloblasto secretor de rato com 14 dias de vida pós-natal do subgrupo de sete ppm

FIGURA 22 Corte ultrafino de ameloblasto secretor de rato com 14 dias de vida pós-natal do subgrupo de 100ppm

FIGURA 23 Corte ultrafino de ameloblasto na fase de maturação com borda rugosa de rato com 14 dias de vida pós-natal do subgrupo de $100 \mathrm{ppm}$ 
TABELA 1 Média e desvio-padrão do comprimento de matriz do esmalte dos

grupos de tratamento com flúor para ratos com 0,7 e 14 dias de vida pós-natal

TABELA 2 Média e desvio-padrão dos parâmetros morfométricos obtidos para ameloblastos do grupo de ratos recém-nascidos

TABELA 3 Média e desvio-padrão dos parâmetros morfométricos obtidos para ameloblastos do grupo de ratos com sete dias de vida pós-natal

TABELA 4 Média e desvio-padrão dos parâmetros morfométricos obtidos para 128 ameloblastos do grupo de ratos com 14 dias de vida pós-natal 
(verso da folha comum) 


\section{LISTA DE SIGLAS, SÍMBOLOS E PALAVRAS DE LÍNGUA ESTRANGEIRA}

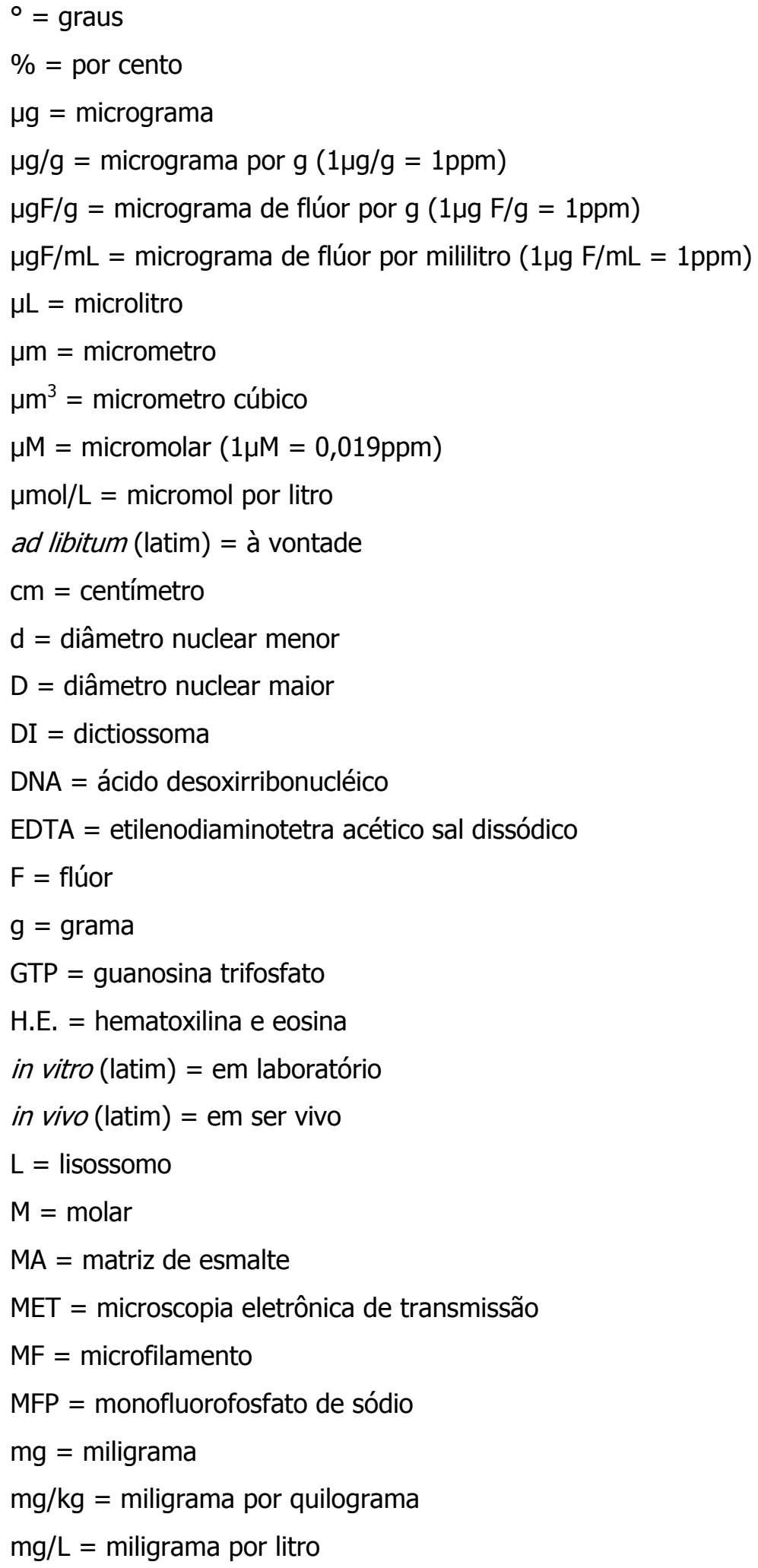


$\mathrm{mgF} / \mathrm{kg}$ = miligramas de flúor por quilo

$\mathrm{mgNaF} / \mathrm{kg}$ = miligramas de fluoreto de sódio por quilo

$\mathrm{MI}=$ mitocôndria

$\mathrm{ml} / \mathrm{g}=$ mililitros por grama

$\mathrm{mm}=$ milímetro

$\mathrm{mM}=\operatorname{milimolar}(1 \mathrm{mM}=19 \mathrm{ppm})$

$\mathrm{MMP}=$ metaloproteinase da matriz

MO = microscopia óptica

$\mathrm{N}=$ núcleo

$\mathrm{n}$ = número de animais da amostra

$\mathrm{NaF}=$ fluoreto de sódio

$\mathrm{NaSn}_{2} \mathrm{~F}_{5}=$ fluoreto estanoso de sódio

$\mathrm{ng} / \mathrm{g}=$ nanogramas por grama

$\mathrm{ng} / \mathrm{L}=$ nanograma por litro

$\mathrm{nm}=$ nanômetro

$\mathrm{NU}=$ nucléolo

$\mathrm{p}=$ nível de significância, probabilidade

p.a. = pró análise

ppm = parte por milhão

$\mathrm{pH}=$ potencial hidrogeniônico

$\mathrm{PT}=$ processo de Tomes

REG = retículo endoplasmático granular ou rugoso

Scel = área ocupada pela célula

Scit = área ocupada pelo citoplasma

$\mathrm{SnF}_{2}=$ fluoreto de estanho

Svcit $=$ densidade de volume citoplasmático

Svn = densidade de volume nuclear

$\mathrm{V}=$ vacúolo

Vcit $=$ volume citoplasmático

$\mathrm{VD}=$ vacúolo digestivo

$\mathrm{V} n=$ volume nuclear

$\mathrm{Vvn}=$ densidade de volume nuclear

Vvcit = densidade de volume citoplasmático

$\mathrm{x}=$ vezes aumentadas de uma imagem 


\section{RESUMO}

A fluorose dentária resulta da toxicidade do flúor durante a odontogênese. Vários modelos experimentais têm sido utilizados para tentar explicar a patogênese do flúor no esmalte, mas durante o período fetal e pós-natal inicial, pouco se conhece a respeito da sua ação. Por isso, no atual trabalho, foram utilizadas ratas que receberam 0, 7 ou 100ppm de fluoreto de sódio na água de beber, no período a partir de uma semana antes do acasalamento, durante toda gestação e durante o aleitamento. As hemimandíbulas dos filhotes com 0 , 7 e 14 dias de vida pós-natal $(n=6)$ foram coletadas para o estudo morfológico em microscopia óptica e eletrônica, análise imuno-histoquímica para amelogenina e estudo morfométrico da matriz de esmalte e dos ameloblastos nas fases de secreção e maturação do incisivo inferior. Os resultados mostraram em ameloblastos secretores do grupo experimental de $100 \mathrm{ppm}$ em todos períodos experimentais: uma menor secreção de matriz de esmalte, a desorganização das cristas das mitocôndrias, o aparecimento de grandes vacúolos na região apical do citoplasma, o acúmulo de material intracisternal e a dilatação de algumas cisternas de retículo endoplasmático rugoso. Nos grupos de animais com 7 e 14 dias, a análise de variância (ANOVA) mostrou uma redução significativa $(p<0,05)$ no volume citoplasmático, respectivamente, de $23,80 \%$ e $24,75 \%$ em relação aos grupos controles. Nos ameloblastos em maturação de borda lisa, foi observada uma grande quantidade de vacúolos com matriz eletrondensa endocitada, sugerindo retardo na reabsorção. Nos ameloblastos de borda rugosa, foi observada a presença de algumas mitocôndrias dilatadas. A análise imuno-histoquímica mostrou que não houve diferença na intensidade e no padrão de marcação da matriz de esmalte em nenhum dos grupos estudados. Portanto, parte do fluoreto de sódio administrado em excesso à mãe na água de beber pode alcançar o filhote pela placenta e pelo leite materno, provocando alterações morfológicas observadas em ameloblastos que sugerem uma redução na secreção e um retardo na reabsorção da matriz de esmalte. 


\section{Introdução}

A presença excessiva de flúor durante a formação do esmalte provoca a fluorose dentária, visualizada clinicamente como manchas ou zonas de hipomineralização no esmalte (DEAN ${ }^{39}, 1942$; FEJERSKOV et al. ${ }^{65}$, 1994). Em ratos, a administração prolongada de flúor, pode provocar alterações como a formação de cistos, calcificações de aspecto amorfo e proliferação papilar no órgão do esmalte. Essas alterações são menos acentuadas no início da formação da matriz de esmalte e na mineralização inicial, onde o ameloblasto encontra-se na sua fase secretora (DAJEAN; MENANTEAU ${ }^{38}$, 1989; DENBESTEN; THARIANI ${ }^{47}$ ， 1992; RIBEIRO; ASSIS; HIROTA ${ }^{140}$, 2001; ROBINSON; KIRKHAM ${ }^{142}$, 1990). Na fase de maturação, são observadas as maiores alterações na matriz pela influência do flúor, como a perda parcial ou completa da pigmentação do esmalte de incisivos de ratos (DENBESTEN; CRENSHAW ${ }^{44}$, 1984), diminuição do índice de reabsorção extracelular das proteínas da matriz (COSTA ${ }^{33}$, 2000; DENBESTEN ${ }^{41}$, 1986; DENBESTEN; CRENSHAW ${ }^{44}$, 1984) e hipomineralização do esmalte (ROBINSON; KIRKHAM ${ }^{142}$, 1990).

Todas essas alterações ainda não estão devidamente esclarecidas, mas alguns autores suspeitam que dependendo da sua concentração o flúor possa interferir também na atividade extracelular das proteinases necessárias para degradar as amelogeninas durante a maturação do esmalte (AOBA ${ }^{4}$, 1994; SMITH et al. ${ }^{164}$, 1989) ou formar a fluorapatita, que dificultaria a ação das proteinases (DAJEAN; MENANTEAU ${ }^{38}$, 1989; ROBINSON; KIRKHAM ${ }^{142}$, 1990). Possivelmente o flúor também possa alterar o balanço do íon cálcio, dificultando o crescimento dos cristais do esmalte (AOBA ${ }^{4}, 1994$; ROBINSON; KIRKHAM ${ }^{142}$, 1990). Tanto as dosagens crônicas como as agudas de flúor provocam alterações na ultraestrutura do ameloblasto de dentes de rato, como a atrofia da porção distal, dilatação de mitocôndrias, distensão e acúmulo de material de 
secreção no retículo endoplasmático (KRUGER ${ }^{94}, 1968$; RIBEIRO ${ }^{139}$, 2001; RIBEIRO; ASSIS; HIROTA ${ }^{140}$, 2001), acúmulo aumentado de vacúolos claros (KRUGER $^{94}$, 1968; OLIVEIRA ${ }^{128}$, 1988; WALTON; EISENMANN ${ }^{178}$, 1974) e de corpos escuros no citoplasma, aumento de grânulos de secreção na região apical, fragmentação e redução do processo de Tomes. Além disso, também pode ocorrer uma desorganização do aspecto prismático das células (LYARUU et al. ${ }^{107}, 1986$; WALTON; EISENMANN ${ }^{178}$, 1974) e uma redução do número de ameloblastos de porção terminal lisa durante a sua modulação da fase de secreção para maturação nos incisivos de ratos (SMITH; NANCI; DENBESTEN ${ }^{164}$, 1993). Estudos utilizando ameloblastos cultivados in vitro têm indicado que o excesso de flúor possa causar um estresse no retículo endoplasmático granular (REG) alterando a síntese protéica (KUBOTA et al. ${ }^{98}$, 2005) ou uma interferência no citoesqueleto do ameloblastos, prejudicando tanto a via de síntese, quanto a de reabsorção das proteínas do esmalte (LI et al. $\left.{ }^{103}, 2005\right)$.

A maioria dessas pesquisas foi realizada em animais adultos, mas sabese que o flúor durante a gestação pode atravessar a placenta, tanto de humanos (AVERY ${ }^{13}$, 2005; FASSMAN ${ }^{62}$, 1993; TEN CATE ${ }^{172}$, 2001) quanto de ratos (KATZ; STOOKEY ${ }^{91}, 1973$ ), podendo estar presente também no leite materno (AVERY ${ }^{13}, 2005$; BUTTNER; MUHLER ${ }^{24}, 1958$; DRINKARD; DEATON; BAWDEN $^{54}$, 1985).

Assim, o flúor pode atingir os tecidos dentários (DRINKARD; DEATON; BAWDEN $^{54}$, 1985; GEDALIA; SHAPIRA ${ }^{71}$, 1989), alterando 0 seu desenvolvimento durante o período fetal ou pós-natal inicial (MACIEJEWSKA; ADAMOWICZ-KLEPALSKA ${ }^{108}$, 2000; MACIEJEWSKA et al. ${ }^{109}$, 2000; MATSUO et al. ${ }^{12}$, 1996). Entretanto, ainda faltam informações morfológicas que mostrem a interferência do flúor na amelogênese durante os períodos gestacionais e na amamentação.

Desta forma, no atual trabalho, foram verificadas possíveis alterações em incisivos inferiores de ratos com 0, 7 e 14 dias de vida pós-natal, cujas mães receberam água deionizada com 0,7 ou 100ppm de flúor no período a partir de uma semana antes do acasalamento das ratas, durante a gestação e a 
amamentação até o momento da eutanásia. Os incisivos inferiores dos filhotes foram analisados em estudo imuno-histoquímico utilizando anticorpos primários contra amelogenina, descrição morfológica em imagens obtidas no Microscópio Óptico (MO) e Microscópio Eletrônico de Transmissão (MET) e avaliação morfométrica em microscopia óptica da matriz e ameloblastos nas fases de secreção e maturação. 
6

Introdução 


\section{Revisão de Literatura}




\section{Revisão de literatura}

Complementando as considerações apresentadas na introdução, será apresentada uma revisão de literatura, ordenada em partes específicas para facilitar o entendimento do tema proposto:

- A passagem do flúor pela placenta

- O flúor presente no leite materno

- Os efeitos do flúor sobre o esmalte dentário

- Os efeitos do flúor sobre os ameloblastos

- Alterações morfológicas provocadas pelo flúor em ameloblastos

- Alterações na modulação de ameloblastos causadas pelo flúor 


\section{1 A passagem do flúor pela placenta}

A ingestão pré-natal de flúor deve ser considerada como fator importante no desenvolvimento pós-natal do esmalte. Estudos em cobaias têm demonstrado que filhotes expostos à fluoretação antes do nascimento apresentam mais flúor no esqueleto e no esmalte (PARKER; BAWDEN ${ }^{132}$, 1986).

O flúor ingerido pela mulher grávida atinge a corrente sangüínea, passando pela barreira placentária (onde é parcialmente armazenada) e alcançando a circulação sangüínea do feto (FELTMAN; KOSEL ${ }^{67}$, 1955; FELTMAN; KOSEL ${ }^{68}$, 1961; GARDNER et al. ${ }^{70}$, 1952; GEDALIA et al. ${ }^{73}$, 1961).

A placenta humana retira parte significativa do flúor. Este fato pode ser comprovado quando se comparam os níveis de flúor no plasma materno e fetal. Devido à barreira placentária, os níveis de fluoreto na circulação sangüínea do feto são relativamente mais baixos quando comparados aos níveis maternos $\left(\right.$ AVERY $\left.^{13}, 2005\right)$.

ARMSTRONG; SINGER; MAKOWSKI ${ }^{11}$, 1970, coletaram amostras de plasma sangüíneo materno e do cordão umbilical de seis mulheres no momento da cesariana. Neste trabalho, não houve controle da dieta, nem foi informada a quantidade de flúor disponível na água de abastecimento. Por colorimetria e análise de absorção atômica, foi constatado um nível de flúor de 0,10ppm no plasma sangüíneo obtido de uma veia materna e de 0,11ppm no coletado a partir de uma artéria materna. No plasma fetal obtido tanto da artéria quanto da veia umbilical, o valor observado foi de 0,14ppm, sem diferença estatisticamente significante com os valores maternos.

LOUW; VAN WYK ${ }^{106}$, 1984, realizaram um estudo semelhante analisando material coletado de dez mulheres no momento da cesariana. Neste trabalho, também não foi informado o nível de flúor da água de abastecimento, nem houve controle da dieta. Estes autores obtiveram, por técnica de eletrodo seletivo para flúor, um valor de $0,27 \mathrm{mg} / \mathrm{L}$ de flúor no plasma materno e 
$0,25 \mathrm{mg} / \mathrm{L}$ no plasma fetal, não havendo diferença estatisticamente significante entre estes valores.

MONTHERRAT-CARRET et al. ${ }^{116}$, 1996, analisaram o nível de flúor no plasma materno e da veia do cordão umbilical de mães que residiam em áreas fluoretadas (onde havia mais de 0,7 partes $/ 10^{6}$ de flúor na água de beber) e não fluoretadas (onde havia menos de 0,1 partes $/ 10^{6}$ de flúor na água de beber). Utilizando um eletrodo íon-específico, foi obtida uma média de 0,034 partes $/ 10^{6}$ de flúor $(1,79 \mu \mathrm{M})$ no plasma materno e 0,031 partes $/ 10^{6}$ de flúor $(1,63 \mu \mathrm{M})$ no plasma obtido do sangue da veia do cordão umbilical. Neste trabalho, os autores não indicaram as médias para as amostras obtidas de áreas fluoretadas e não fluoretadas, uma vez que havia um número reduzido de amostras (dez fetos oriundos de áreas fluoretadas e três de áreas não fluoretadas). A razão entre a concentração de flúor no plasma materno e do plasma da veia do cordão umbilical foi de 1,1, o que confirma a transferência de flúor pela placenta, quando a administração de flúor é baixa. Neste mesmo trabalho, foi verificado que a concentração de flúor no germe dentário e na mandíbula aumenta de acordo com o nível de flúor na água de beber, sugerindo mais uma vez a passagem de flúor pela placenta.

A ação da barreira placentária pode ser observada também quando se analisa a deposição de flúor em tecidos duros. GEDALIA; ZUKERMAN ${ }^{72}, 1965$, analisaram por colorimetria a quantidade de flúor presente nos ossos femurais, mandíbula e dentes de 71 fetos de cinco a nove meses de idade que sofreram aborto espontâneo ou morte prematura ainda na vida intra-uterina. As mães residiam em Israel, onde o nível de flúor na água era de 0,5 a 0,6ppm ou $1 \mathrm{ppm}$. Foi verificado que o conteúdo de flúor nos ossos e dentes aumentava com o avanço da idade do feto, sendo este aumento maior no osso e menor no dente. Existiram algumas diferenças estatísticas entre os grupos, mas não houve um aumento diretamente proporcional. Por exemplo, no dente de fetos cujas mães recebiam 0,5ppm de flúor na água de beber, foram observadas concentrações de flúor de 2,63, 3,26, 4,30,5,79 e 6,97mg/100g de cinza, respectivamente para fetos nas idades de 5, 6, 7, 8 e 9 meses. Para os fetos cujas mães recebiam 1ppm, os valores foram de 4,40, 4,70, 5,20 e 
$5,38 \mathrm{mg} / 100 \mathrm{~g}$ de cinza, respectivamente para os fetos de 6, 7, 8 e 9 meses de idade (não houve amostra de fetos com 5 meses de idade). Desta forma, a placenta parece representar uma barreira parcial à passagem de quantidades maiores de flúor.

Mas a placenta não permite a passagem de todo o flúor plasmático ao feto. Existe também um acúmulo de flúor no tecido placentário, mesmo quando baixas doses são administradas. GEDALIA et al. ${ }^{73}, 1961$, analisaram por colorimetria a concentração de flúor na placenta, cordão umbilical e plasma sangüíneo materno de 25 mulheres saudáveis, próximo ao parto, as quais viviam em Jerusalém em áreas cujo nível de flúor na água de abastecimento era de 0,55ppm. O nível médio de flúor na placenta $(0,15 \mathrm{ppm})$ foi significantemente maior que o do plasma sangüíneo obtido do cordão umbilical $(0,11 \mathrm{ppm})$ e do sangue materno (0,09ppm). Não houve diferença estatística entre a concentração de flúor do plasma sangüíneo materno e do cordão umbilical. Um fato bastante interessante, é que o plasma coletado de mulheres não grávidas apresentava um nível de flúor $(0,18 \mathrm{ppm})$ maior que das mulheres grávidas, o que poderia sugerir o acúmulo de flúor na placenta durante a gravidez e a remoção do mesmo da corrente sangüínea da mãe. Em todos os casos, a concentração de flúor na placenta foi maior que a observada no plasma materno. O fato da concentração média de flúor ser maior na placenta que no cordão umbilical e que existe uma correlação positiva entre eles, indica que a placenta permite a passagem de flúor ao feto. Porém, parte do flúor deve se acumular no tecido placentário, obstruindo parcialmente a sua transmissão ao feto; uma vez que não houve diferença estatística entre a concentração média de flúor no plasma sangüíneo materno e no cordão umbilical.

A passagem de flúor através da placenta e seu acúmulo na mesma está relacionada com a quantidade de flúor administrada durante a gravidez. GEDALIA et al. ${ }^{74}, 1964$, estudaram três grupos de mulheres grávidas. O grupo I estava composto por 39 mulheres de Upper Galilee e Tel-Aviv em áreas onde a água de abastecimento continha 0,06 a 0,15ppm de flúor, sendo considerada uma baixa concentração. O grupo II estava formado pode 20 mulheres de Kiriath-Chaim que bebiam água de abastecimento contendo 0,6 a 0,9ppm de 
flúor, considerada uma alta concentração. E no grupo III havia 18 mulheres de Jerusalém que residiam em áreas onde o nível de flúor era de 0,5 a 0,6ppm de flúor (concentração média) e que recebiam também um tablete de $0,5 \mathrm{mg}$ de $\mathrm{NaF}$ por dia. Nas análises de flúor da placenta e do plasma sangüíneo foi utilizada a técnica da colorimetria. No grupo I (baixa concentração), o nível de flúor no cordão umbilical $(0,165 \mathrm{ppm})$ foi significantemente maior que o observado na placenta $(0,121 \mathrm{ppm})$ e no plasma materno $(0,150 \mathrm{ppm})$. Entretanto, os valores obtidos para placenta e plasma materno não foram significantemente diferentes. Entre os grupos II e III (alta concentração), as diferenças entre o nível de flúor na placenta, cordão umbilical e sangue materno foram insignificantes. Na obtenção das médias, os resultados de ambos os grupos foram reunidos. Portanto, no grupo de alta concentração, o nível de flúor do cordão umbilical $(0,175 \mathrm{ppm})$ foi significantemente menor que o observado na placenta $(0,228 \mathrm{ppm})$ e no plasma materno $(0,234 \mathrm{ppm})$. Os valores observados para o tecido placentário e o plasma materno não foram estatisticamente significantes. Quando se comparou o resultado dos grupos de baixa e alta concentração de flúor, os valores obtidos para o cordão umbilical não apresentaram diferenças estatisticamente significantes. Entretanto, os níveis de flúor na placenta e no plasma materno foram significantemente maiores no grupo de alta concentração que no de baixa. Estes resultados sugerem que quando a concentração é baixa, o flúor atravessa livremente a placenta, mas quando o consumo é alto, a placenta regula a sua passagem, protegendo o feto do excesso.

Este fato pode ser verificado pelo nível de flúor analisado no esmalte produzido no período pré- e pós-natal. TOYAMA et al. ${ }^{176}, 2001$, mensuraram a concentração de flúor de incisivos e caninos decíduos de esfoliados de crianças que residiam em áreas naturalmente fluoretadas $\left(1,0\right.$ a 1,3 partes $/ 10^{6}$ de flúor na água de beber) em West Hartlepool e de regiões não fluoretadas (menos de 0,1 partes $/ 10^{6}$ de flúor na água de beber) em Leeds na Inglaterra. Utilizando um eletrodo íon-específico, foram analisadas camadas de $100 \mu \mathrm{m}$ antes e depois da linha neonatal, as quais correspondem a áreas de esmalte pré- e pós-natal, respectivamente. Foi verificado que não houve diferença estatística entre o 
nível de flúor no esmalte sintetizado nos períodos pré- e pós-natal, mas a concentração de flúor foi maior no esmalte de dentes de crianças residentes em área fluoretada. Desta forma, o flúor passa pela placenta, mesmo quando é administrado na água de beber em doses abaixo da ideal (no caso 0,1ppm de flúor), mas não é acumulado significativamente no esmalte dentário.

Em animais, existem vários relatos na literatura abordando também a transferência do flúor através da placenta. Não existem dúvidas que o flúor passe pela barreira placentária, atingindo os tecidos fetais (ERICSSON; ULLBERG $^{60}$, 1958; FASSMAN ${ }^{62}$, 1993; KATZ; STOOKEY ${ }^{91}$, 1973; MAPLESDEN et al. ${ }^{110}$, 1960; THEUER; MAHONEY; SARETT ${ }^{174}$, 1971; THYLSTRUP ${ }^{175}$, 1981) e podendo alcançar estruturas dentárias fetais em diversas espécies de animais (DRINKARD; DEATON; BAWDEN ${ }^{54}$, 1985; GEDALIA; SHAPIRA ${ }^{71}$, 1989; ZIPKIN; BABEAUX $\left.{ }^{186}, 1965\right)$.

Embora a placenta permita a transferência de flúor ao feto, existe uma retenção proporcionalmente maior quanto maior for a sua ingestão. Sabe-se também que a exposição de flúor antes da gestação causa um aumento na quantidade de flúor transferido pela placenta durante a gravidez. Embora não haja informações suficientes para elucidar o mecanismo pelo qual este processo ocorre, o flúor provavelmente deva ser armazenado no esqueleto antes da gravidez e durante este período seja mobilizado e transferido aos filhotes. Assim, o flúor consumido na água de beber antes, durante ou antes e durante a gestação é transferido parcialmente à prole, devido ao fato da placenta ser permeável ao flúor e parte ficar retida nos ossos (KATZ; STOONEY ${ }^{91}$, 1973).

Em ratos, como nos humanos, a placenta bloqueia parcialmente a passagem do flúor da mãe ao feto (KATZ; STOONEY ${ }^{91}$, 1973; MAPLESDEN et al. $^{110}$, 1960; THYLSTRUP ${ }^{175}$, 1981).

A ação da placenta como barreira ao flúor pode ser verificada também quando se compara a passagem de flúor da mãe para o filhote nos períodos pré- e pós-natal. MAPLESDEN et al. ${ }^{110}, 1960$, verificaram, utilizando técnica de destilação, o nível de flúor na carcaça de fetos e filhotes de ratos SpragueDawley cujas mães receberam 0, 50, 100, 200 e 300ppm de flúor adicionados em uma dieta sólida de 3ppm de flúor. Os autores não descreveram se as mães 
recebiam esta mesma dieta ou água fluoretada antes do acasalamento. Nos fetos nos $21^{\circ}$ dia de gestação, foram observados níveis de flúor de $0,1,0 \pm 1,2$, $1,8 \pm 0,8$ e 4,1 \pm 1,3ppm, respectivamente para os grupos de 0, 50, 100 e 200ppm. Ao nascimento, as carcaças dos filhotes dos grupos de 0, 50, 100, 200

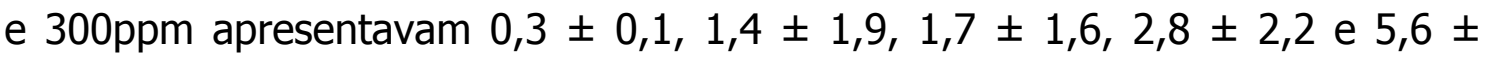
2,8ppm; e aos 21 dias de vida pós-natal, apresentavam 0,0, 2,1 $\pm 1,1,4,7 \pm$ $2,4,10,1 \pm 5,9$ e 9,9 \pm 2,3ppm. Este experimento foi repetido em ratas Wistar, onde foram observados valores de 0,0, 0,6 $\pm 0,1$ e 3,5 $\pm 3,5 p p m$ de flúor em recém-nascidos cujas mães receberam 0, 50 e 300 ppm de flúor.

A quantidade de flúor retida na placenta foi mensurada por THEUER; MAHONEY; SARETT ${ }^{174}$, 1971. Neste estudo, os pesquisadores avaliaram, por espectrofotometria, o nível de flúor encontrado nas cinzas das placentas e de fetos de ratos Sprague-Dawley com 20 dias de gestação, cujas mães receberam dieta sólida fluoretada. Durante 12 semanas, as ratas recebiam uma dieta com baixo nível de flúor. Após este período, ocorria o acasalamento e as ratas prenhes recebiam ração com 0, 50, 100 e 200ppm de flúor. Os autores realizaram vários experimentos utilizando diferentes formas de flúor ( $\mathrm{NaF}$, $\mathrm{NaSn}_{2} \mathrm{~F}_{5}, \mathrm{SnF}_{2}$ e NaF $+\mathrm{SnF}_{2}$ ), mas não observaram diferenças estatisticamente significantes nos resultados obtidos. Na placenta dos fetos cujas mães receberam NaF, o nível de flúor foi de 0,4,1,1 e 1,1ppm; e nos fetos, o nível foi de 0,65, 1,15 e 3,02ppm, respectivamente para os grupos de 50, 100 e 200ppm. Desta forma, o nível de flúor fetal é consideravelmente maior que o da placenta. A análise estatística revelou um aumento significativo apenas nos animais cujas mães que receberam 200ppm.

A retenção de flúor tem como objetivo proteger o feto contra quantidades tóxicas de flúor que possam alterar o desenvolvimento ou crescimento fetal (THYLSTRUP ${ }^{175}$, 1981). O flúor, que não foi retido, consegue atravessar a barreira placentária e circula no plasma sangüíneo, depositando-se parcialmente no esqueleto fetal (ERICSSON; ULLBERG ${ }^{60}$, 1958). Desta forma, o acúmulo no esqueleto fetal é menor do que o acumulado no materno (ERICSSON; HAMMARSTRÖM ${ }^{59}$, 1964). 
Vários estudos demonstraram que o flúor não apenas é capaz de atravessar a placenta como também está presente no plasma sangüíneo e é armazenado nos tecidos fetais (COHEN; WINER; CURBY ${ }^{32}$, 1959), inclusive no esmalte dentário (BAWDEN et al. ${ }^{16}$, 1989; BAWDEN et al. ${ }^{17}$, 1992; PARKER; BAWDEN $\left.^{132}, 1986\right)$.

Estudos sugerem que seja necessária uma dieta de pelo menos 10 a $15 \mathrm{ppm}$ de flúor para ser observado um aumento significante no conteúdo total de flúor em cinzas cremadas dos filhotes. BUTTNER; MUHLER ${ }^{24}$, 1958, utilizaram ratas que receberam $0,1,3,5,10,25$ e 50ppm de flúor na forma de $\mathrm{NaF}$ em água de beber e ração contendo $1,0 \mu \mathrm{gF} / \mathrm{g}$ durante a prenhez. Os filhotes foram sacrificados no momento do nascimento, com 10 e 30 dias de vida pós-natal para análise de flúor nas cinzas da carcaça cremada. Foi verificado que é necessária a administração de pelo menos 10ppm de flúor na água de beber para que seja observado um aumento significante no conteúdo total de flúor nos filhotes. Enquanto o nível de flúor nos filhotes recém-nascidos cujas mães receberam $5 p p m$ foi de $5,2 \mu \mathrm{g}$, nos filhotes cujas mães receberam

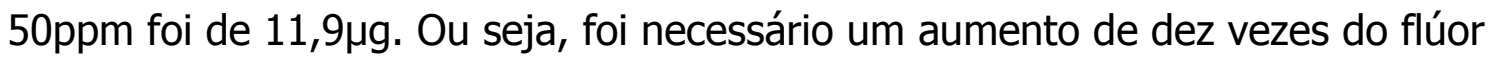
na água de beber das mães para dobrar a quantidade do flúor na carcaça dos filhotes. Devido ao fato da placenta atuar como barreira à passagem do flúor, não se pode fazer uma correlação direta entre o aumento de flúor na dieta com o valor esperado nos filhotes.

BRZEZINSKI et al. $^{21}$, 1961, estudaram cinco grupos de ratas que receberam os seguintes tratamentos:

- grupo I: ração com 0,20ppm de flúor e água com zero ppm de flúor;

- grupo II: ração com 0,20ppm de flúor e água com cinco ppm de flúor;

- grupo III: ração com 4,55ppm de flúor e água com 0,65 ppm de flúor;

- grupo IV: ração com 4,55ppm de flúor e água com 10 ppm de flúor;

- grupo V: ração com 4,55ppm de flúor e água com 50 ppm de flúor;

- grupo VI: ração com 4,55ppm de flúor e água com 100 ppm de flúor.

Os filhotes de cada grupo foram sacrificados logo após o nascimento para análise de flúor por colorimetria. Foi verificado que é necessária uma dieta de pelo menos 10 a $15 \mathrm{ppm}$ de flúor para ser observado um aumento 
significante no conteúdo total de flúor em cinzas cremadas dos ossos dos filhotes.

Em pesquisas experimentais para avaliar o acúmulo de flúor em tecidos fetais, deve ser considerado também o tempo de exposição do mesmo. 0 tempo de administração deste íon parece ser importante não apenas quando se estuda o esmalte, mas também o tecido ósseo, e também pode ser válido para o período pós-natal. Assim, quanto maior é o tempo de exposição ao flúor, maior o acúmulo de flúor em tecidos ósseos (WEDDLE; MUHLER ${ }^{181}$, 1955).

Ao estudar a transferência do flúor através da placenta, deve ser levada em conta também a retenção do flúor no esqueleto da mãe. Doses agudas de fluoreto de sódio injetadas em ratos adultos podem acarretar fluorose no esmalte subseqüentemente irrompido, mesmo após os índices altos de flúor plasmático terem retornado aos níveis basais (ANGMAR-MANSSON; WHITFORD ${ }^{2}$, 1983).

Em animais adultos, foi verificado que o flúor parece ser mobilizado do osso adjacente para o órgão do esmalte, resultando numa concentração de flúor local suficiente para afetar a amelogênese e agravar as alterações decorrentes da fluorose (ANGMAR-MANSSON; WHITFORD², 1983; ANGMARMANSSON; LINDH; WHITFORD ${ }^{3}$, 1990; BRÓGLIO20 $\left.{ }^{20} 1994\right)$.

Fica claro então que as alterações provocadas pelo flúor estão intimamente ligadas ao flúor administrado anteriormente ao experimento e que se encontra armazenado no osso. Desta forma, em estudos deve-se considerar também a administração do flúor antes do período gestacional. KATZ; STOONEY ${ }^{91}$, 1973, analisaram o conteúdo de flúor na carcaça de filhotes de ratos cujas mães que receberam água de beber contendo $25 \mathrm{ppm}$ de flúor, na forma de $\mathrm{NaF}$ antes e/ou durante a gestação. Nos animais cujas mães receberam flúor antes da prenhez, foi observada uma quantidade de flúor de $5,63 \mu \mathrm{g}$ por filhote. Nos animais cujas mães receberam flúor durante a prenhez, foi observada uma quantidade de $5,09 \mu \mathrm{g}$ por filhote. Nos animais cujas mães receberam flúor antes e durante a prenhez, foi observada uma quantidade de $7,36 \mu \mathrm{g}$ por filhote. Isto demonstra que a placenta do rato albino é permeável ao flúor se é fornecido numa concentração de $25 \mathrm{ppm}$ na água de beber e se for 
administrado antes e/ou durante o período gestacional. Menos de $1 \%$ do flúor administrado às ratas prenhes durante toda gestação é transferida à prole, devido à ação da presença da barreira placentária. O flúor administrado antes do período gestacional foi parcialmente transferido ao feto através da placenta, provavelmente como resultado da estocagem do mesmo no tecido ósseo materno antes da gestação e a subseqüente mobilização durante a prenhez.

A manutenção deste estado de equilíbrio aparente da concentração de flúor no sangue é função da ingestão continua e parece ser mantido pela concentração de flúor lábil nos ossos $\left(\mathrm{CURY}^{36}, 1984\right)$.

Sendo assim, as modificações celulares ocorridas em detrimento do flúor podem ser dependentes de vários fatores, como a dose, o tempo decorrido após a sua administração, o momento da administração do flúor em relação ao ciclo circadiano, o estágio em que se encontra do ameloblasto no momento de administração da droga, a calcemia e a idade do animal utilizado no experimento e a liberação de cálcio pelo tecido ósseo circunjacente (ANGMARMANSSON; WHITFORD ${ }^{2}$, 1983; DENBESTEN ${ }^{43}$, 1999; DENBESTEN; THARIANI ${ }^{47}$, 1992; KRUGER ${ }^{96}$, 1970; LARSEN; RICHARDS; FEJERSKOV ${ }^{100}$, 1981). 


\section{2 O flúor presente no leite materno}

Independente da via de aplicação, o flúor administrado na fase pré-natal está presente tanto nos tecidos maternos, quanto nos tecidos fetais. Parte do flúor presente no corpo materno pode ser transmitido à criança pelo leite durante o período de amamentação. Entretanto, estudos realizados em humanos demonstraram a presença de pequena quantidade de flúor presente no leite materno. Utilizando um eletrodo íon-seletivo, HOSSNY et al. ${ }^{80}, 2003$, verificaram que o nível de flúor no leite materno é de aproximadamente 0,1 a $0,6 \mu \mathrm{mol} / \mathrm{L}$ em mulheres que residiam no Cairo, onde o nível de flúor na água de abastecimento é de 0,3ppm.

Vários estudos foram realizados comparando o nível de flúor no leite materno em mães que moram em áreas fluoretadas e não fluoretadas. Neste sentido, CHOWDHURY; BROWN; SHEPHERD ${ }^{31}$, 1990, realizaram um estudo utilizando eletrodo íon-específico para mensuração do nível de flúor iônico livre no leite de mães que viviam na Nova Zelândia em áreas fluoretadas $(0,8$ $0,9 \mu \mathrm{gF} / \mathrm{mL})$ e não fluoretadas $(0,09-0,10 \mu \mathrm{gF} / \mathrm{mL})$. Tanto na área fluoretada quanto na área não fluoretada foi observado um valor médio de $0,003 \mu \mathrm{gF} / \mathrm{mL}$, não havendo diferença estatisticamente significante.

A quantidade de flúor é considerada baixa não apenas no leite materno comum, mas também no colostro. SPAK; EKSTRAND; HARDELL ${ }^{166}$, 1983, analisaram o nível de flúor no colostro por técnica de microdifusão em mães que residiam em áreas onde a fluoretação da água era de 0,2 e 1ppm. A concentração de flúor observada foi de $0,30 \pm 0,10 \mu \mathrm{M}$ e 0,36 $\pm 0,15 \mu \mathrm{M}$, respectivamente para os grupos citados anteriormente, sem diferença estatística entre os mesmos. Na região onde o nível de flúor na água era de $1 \mathrm{ppm}$, foram analisadas amostras de leite materno, sendo obtido um valor de $0,38 \pm 0,20 \mu \mathrm{M}$. Isto mostra que crianças alimentadas com leite materno, cujas mães residam em áreas de 0,2 a 1ppm de flúor na água de beber, talvez 
tenham recebido aproximadamente a mesma quantidade de flúor, independente da diferença na ingestão de flúor por suas mães.

O nível de flúor no leite materno está diretamente relacionado com a quantidade presente na água de beber. DABEKA et al. ${ }^{37}, 1986$, coletaram amostras de leite materno de voluntárias do Canadá e verificaram por técnica de microdifusão com eletrodo flúor-específico que a concentração média de flúor no leite materno era de 7,08ng/g. Nas áreas fluoretadas (onde o nível de flúor na água de abastecimento era de $1 \mu \mathrm{g} / \mathrm{g}$ ) a concentração média era de 9,80ng/g e nas áreas não fluoretadas (onde o nível de flúor na água de abastecimento era menor que $0,16 \mu \mathrm{g} / \mathrm{g}$ ) era de $4,41 \mathrm{ng} / \mathrm{g}$, com diferença estatística significativa entre estes grupos. Nesta mesma pesquisa, os autores verificaram outras fontes de flúor como consumo de peixe e suplementos fluoretados ingeridos antes, durante e depois da gravidez. Porém, a água de beber foi a variável mais claramente associada com os níveis de flúor, sendo confirmada pela análise de regressão, a associação entre a concentração de flúor na água de beber e a concentração presente no leite materno.

Desta forma, a quantidade de flúor consumida pela mãe antes e durante a gravidez pode influir na quantidade do flúor no leite materno. ESALA; VUORI $^{61}$, 1982, realizaram um estudo na Finlândia pesquisando o nível de flúor no leite materno de mulheres que residiam em áreas com alta e baixa concentração de flúor na água de abastecimento. Por técnica de microdifusão por eletrodo flúor-seletivo foi verificado que na área de baixa concentração (onde havia $0,2 \mu \mathrm{gF} / \mathrm{mL}$ na água de abastecimento), o nível de flúor iônico no leite materno das mães que residiam nesta região foi de $0,005 \mu \mathrm{gF} / \mathrm{mL}$ e de flúor total foi de $0,007 \mu \mathrm{gF} / \mathrm{mL}$. Na área de alta concentração (onde havia $1,7 \mu \mathrm{gF} / \mathrm{mL}$ na água de abastecimento), o valor obtido foi de 0,009 $\mathrm{gF} / \mathrm{mL}$, sendo este valor significantemente maior que o observado na área de baixa concentração. Entretanto, vale ressaltar que os autores não descreveram se todas as mulheres selecionadas para o estudo haviam nascido em tais regiões ou permanecido toda vida nestas áreas, ou ainda se havia mulheres na amostra que tinham migrado de outras regiões para estas áreas, o que poderia talvez influir nos resultados obtidos. 
Este fato pode ser comprovado no estudo de SIMPSON; TUBA ${ }^{159}, 1968$, os quais analisaram amostras de leite materno coletado de mães que residiam em Edmonton em Alberta (Canadá) por meio de eletrodo específico. Neste trabalho, os autores analisaram amostras de leite materno coletadas dois meses antes e um mês após o início de fluoretação da água de abastecimento. Antes da fluoretação, o nível de flúor na água era de 0,26ppm, passando para 1ppm com o tratamento da água. Foram selecionadas mães que não utilizavam suplementos alimentares fluoretados. Foi verificado que o nível de flúor no leite materno aumentou de 0,20ppm para 0,49ppm após a fluoretação da água, com diferenças estatisticamente significantes entre estas amostras. Todavia, vale ressaltar que as amostras foram coletadas de um hospital local, não estando descrito se havia mulheres de outras cidades, o que talvez pudesse influir nos resultados obtidos.

O nível de flúor no leite materno não acompanha o nível no plasma sangüíneo materno, pelo menos num período após a sua administração. Neste sentido, EKSTRAND; BOUREUS; DE CHATEAU ${ }^{55}$, 1981, administraram uma dose de $1,5 \mathrm{mg}$ de flúor na água de beber em forma de solução aquosa de NaF para cinco mães entre 27 e 36 anos no $3^{\circ}$ dia pós-parto. Foi analisada a quantidade de flúor no plasma sangüíneo materno (com eletrodo flúor-específico) e no leite materno (por técnica de microdifusão) antes, 30, 69, 90 e 120 minutos após a administração do flúor. Foi observado que a concentração de flúor em todos indivíduos aumentou rapidamente após a ingestão de flúor, com pico observado 30 minutos após. Mas não houve um aumento correspondente na quantidade de flúor detectado no leite materno. Isto sugere que durante o período examinado, o flúor seja pobremente transferido ao leite materno, talvez devido ao curto período analisado.

O nível de flúor no leite materno pode variar durante gravidez. LATIFAH; RAZAK $^{101}$, 1989, verificaram o nível de flúor em amostras de leite materno de mães residentes em áreas fluoretadas $(0,7 \mathrm{ppm})$ da Malásia; todas residentes na localidade há mais de um ano e sem receber suplementos ou drogas fluoretadas. A concentração de flúor obtida por meio de eletrodo para flúor variou de 0,024 a 0,172ppm, com valor médio de 0,077ppm, considerado 
relativamente baixo. Em sete mães, foi coletada uma segunda amostra em um outro período da gravidez, entretanto não houve um critério para determinar o momento no qual esta amostra foi coletada. O nível de flúor obtido nestas amostras era variável, podendo ser igual, maior ou até mesmo menor que as coletadas inicialmente. Estas variações podem estar relacionadas a outros fatores não estudados na pesquisa, como a dieta, por exemplo.

A fluoretação da água parece aumentar especialmente o nível de flúor iônico no leite materno. DIRKS et al. ${ }^{52}$, 1974, por cromatografia e eletrodo para flúor verificaram diferenças significantes no nível de flúor iônico presente no leite materno de mães que residiam em áreas fluoretadas e não-fluoretadas. Neste estudo foram analisadas amostras de leite materno de mães no $4^{\circ}$ ou $5^{\circ}$ dia pós-parto que residiam em áreas onde o nível de flúor na água era de 0,1ppm (não-fluoretada) e 1ppm (fluoretada). Os níveis de flúor no leite materno foram de $0,046 \mathrm{ppm}$ e $0,052 \mathrm{ppm}$, respectivamente para os mesmos grupos, sem diferença estatística entre os mesmos. Os níveis de flúor iônico foram de 0,004ppm e 0,008ppm, respectivamente, com diferenças estatísticas entre os mesmos.

Nos estudos em humanos, deve ser considerado também que existe uma variação na quantidade de leite materno ingerida pela criança durante a amamentação. EKSTRAND; HARDELL; SPAK ${ }^{56}, 1984$, analisaram por técnica de microdifusão a quantidade de flúor presente no leite materno de mães que viviam em Estocolmo na Suécia em áreas onde o nível de flúor na água era de $1 \mathrm{ppm}$. A concentração de flúor presente no leite materno variou de $4 \mathrm{a} 8 \mathrm{ng} / \mathrm{mL}$ $(0,2$ a $0,4 \mu \mathrm{M})$. As crianças eram amamentadas de 4 a 9 vezes durante o dia, 0 que resultava numa dose diária de aproximadamente $6 \mu \mathrm{g}$. Os autores atribuíram esta variação ao número de vezes que a criança era amamentada e a quantidade de leite materno ingerido pela criança (sendo uma variável que não pode ser determinada). Neste mesmo estudo, os autores verificaram que as crianças que consumiam fórmulas infantis, além do leite materno, eram mais expostas ao flúor, pois ingeriam de 891 a $1012 \mu \mathrm{g}$ de flúor. Desta forma, para prevenção da fluorose dentária, deve ser preferido adotar uma alimentação 
com leite materno ao invés de fórmulas infantis durante a fase de amamentação da criança.

Um outro fator que dificulta o estudo da passagem do flúor no leite materno em humanos é o controle da dieta da mãe. KOPARAL; ERTUGRUL; OZTEKIN $^{92}$, 2000, analisaram, por eletrodo específico para o flúor, as amostras de leite materno de 57 mães coletadas quatro ou cinco dias após o nascimento de seus filhos. Elas moravam em Izmir em áreas onde o nível de flúor na água de abastecimento era de 0,3ppm e não utilizavam nenhum suplemento fluoretado. O nível de flúor no leite materno foi de 0,019 $\pm 0,004 p p m$, variando de 0,005ppm a 0,025ppm. Entretanto, o trabalho ressalta que 64,91\% das mães consumiam a água de abastecimento e 35,09\% compravam água no mercado.

RAHUL; HEDGE; MUNSHI ${ }^{137}$, 2003, coletaram amostras de leite materno de 20 mães residentes em Mangalore na Índia. Por meio de eletrodo específico, o conteúdo de flúor no leite materno variou de 0,05 a 0,10ppm com uma média de 0,08 $\pm 0,132 \mathrm{ppm}$. Esta variação nos resultados pode-se dever a uma variação na concentração de flúor: na água de abastecimento o nível foi de 0,01ppm, da água obtida em poços abertos foi de 0,02 a 0,04ppm e da água oriunda de poços perfurados foi de 0,04 a 0,05ppm. Neste mesmo estudo, os autores verificaram que o nível de flúor no leite de vaca variava de 0,06 a 0,17ppm, com média de 0,12 $\pm 0,04 p p m$. Em formulações comercializadas à base de leite, o nível de flúor variava de 1,95 a 7,45ppm. Desta forma, outras fontes de flúor na dieta devem ser consideradas quando se estudam os efeitos do flúor em humanos.

Em humanos, a glândula mamária atua como uma barreira à passagem do flúor, assim como a placenta. EKSTRAND et al. ${ }^{57}$, 1984, realizaram o estudo de um caso onde foram avaliadas amostras de leite materno coletado de uma mãe que ingeria altas dosagens de flúor por motivo de tratamento de osteoporose. A paciente tinha 33 anos e era tratada com duas doses diárias de tabletes de $25 \mathrm{mg}$ de NaF durante um mês. O experimento ocorreu sete meses após o parto e quando a produção de leite materno era normal. A paciente ficava em jejum oito horas antes do início do experimento e em seguida ingeria 
a dose oral de $25 \mathrm{mg}$ de NaF. Amostras de sangue venoso foram coletadas após $0,2,4,6$ e $8 \mathrm{~h}$. Amostras de leite materno foram coletadas 15 minutos antes e 0,$5 ; 1 ; 1,5 ; 2 ; 4 ; 6$ e 8 horas após a ingestão do tablete. 0 nível de flúor plasmático foi verificado utilizando um eletrodo específico para o íon flúor e no leite materno pela técnica de microdifusão modificada. Os picos de flúor no plasma materno e no leite materno ocorreram duas horas após a ingestão, entretanto os valores observados para o leite materno foram menores que os plasmáticos. Neste momento, a razão entre o flúor plasmático e no leite materno foi de 0,21 e após oito horas aumentou para 0,32. Duas horas após a administração de flúor, a concentração começou a declinar, mas não retornou a níveis basais mesmo após oito horas. Assim, um pequeno aumento na concentração de flúor no leite materno ocorre quando a mãe recebe altas dosagens de flúor. Mesmo quando a mãe recebe uma alta dosagem de flúor (25mg), a criança recebe no máximo uma dose de $30 \mu \mathrm{g}$ de flúor por dia ou $0,2 \%$ da dose ingerida pela mãe. Isto representa apenas $3 \%$ da dose comparada à quantidade diária ingerida pela criança, quando ela é alimentada com mamadeira. Com uma fórmula infantil diluída em água contendo 1ppm de flúor, a criança recebe aproximadamente $1 \mathrm{mg}$ por dia. Assim, a quantidade de flúor ingerida pela criança no leite materno é muito baixa quando comparada com outras fontes, como a água de beber fluoretada.

Em ratos, por outro lado, a glândula mamária parece poder concentrar o flúor no leite materno, uma vez que os níveis neste são maiores que os plasmáticos. O nível de flúor no leite materno foi avaliado por DRINKARD; DEATON; BAWDEN ${ }^{54}$, 1985, utilizando método de microdifusão rápida com eletrodo íon-específico. Foram utilizadas ratas prenhes que receberam 0 (grupo I), 50 (grupo II) e 100ppm (grupo III) de flúor na água de beber no início da prenhez. As mães e os filhotes foram sacrificados 13 dias após o parto, sendo determinado os níveis de flúor no plasma sangüíneo das mães e dos filhotes, no leite materno e no esmalte dos dentes molares dos filhotes. A concentração média de flúor plasmático materno foi de 0,02, 0,10 e 0,21ppm para os grupos I, II e III, respectivamente. Os valores de flúor no leite materno foram aproximadamente duas vezes mais alto que os plasmáticos, com valores de 
0,044, 0,349 e 0,401ppm para os grupos I, II e III, respectivamente. As concentrações de flúor plasmático nos filhotes foram de 0,003, 0,005 e 0,006ppm respectivamente nos grupos I, II e III. As concentrações de flúor no esmalte dos filhotes foram de $0,62,4,72$ e $8,80 \mathrm{ppm}$ para os grupos I, II e III, respectivamente. Desta forma, foi observado que os níveis de flúor no plasma e, especialmente, no leite materno são muito maiores que os observados no plasma e no esmalte dos filhotes; sendo estes valores ligeiramente aumentados quando altas doses eram oferecidas às mães.

Num outro estudo também realizado em ratos, CHAN et al. ${ }^{29}, 1989$, foram utilizadas 16 ratas Sprague-Dawley divididas em quatro grupos: (a) receberam ração com baixa dosagem de flúor $\left(0,5\right.$ partes $\left./ 10^{6} \mathrm{~F}\right)$ antes da prenhez até 13 dias após o nascimento dos filhotes; (b) receberam ração com dosagem regular de flúor (28-32 partes $/ 10^{6} \mathrm{~F}$ ) antes da prenhez até 13 dias após o nascimento dos filhotes; (c) receberam 100 partes $/ 10^{6} \mathrm{~F}$ durante a prenhez (3 semanas) e a mesma ração com dosagem regular de flúor antes da prenhez até 13 dias após o nascimento dos filhotes; e (d) receberam 100 partes $/ 10^{6} \mathrm{~F}$ por três semanas antes da prenhez e a mesma ração com dosagem regular de flúor antes da prenhez até 13 dias após o nascimento dos filhotes. Após 13 dias depois do nascimento, os filhotes e as mães foram sacrificados para análises do conteúdo de flúor por método de microdifusão. Foi observado que os níveis de flúor no plasma e no leite materno aumentaram proporcionalmente com os níveis de flúor na dieta. Os níveis de flúor do plasma materno foram de $0,020,0,069,0,117$ e 0,090 partes $/ 10^{6}$, respectivamente para os grupos a, b, c e d. Os níveis de flúor no leite materno foram de 0,033, $0,103,0,128$ e 0,112 partes $/ 10^{6}$, respectivamente para os grupos $a, b, c$ e d. No plasma sangüíneo dos filhotes, os valores foram de 0,008, 0,012, 0,015 e 0,011 partes $/ 10^{6}$ para os mesmos grupos. Para os incisivos inferiores (considerando todo o dente) dos filhotes os valores foram de 32,8, 41,9, 57,1 e 45,5 partes $/ 10^{6}$, respectivamente para os mesmos grupos. Para as epífises femorais dos filhotes, as concentrações foram de 117,0, 161,0, 222,6 e 178,5 partes $/ 10^{6}$, respectivamente. Assim, a suplementação de flúor durante a prenhez (grupo c) aumentou a concentração em incisivos inferiores $36 \%$, e 
antes da prenhez (grupo d) aumentou apenas 9\%, quando comparados com os animais que receberam ração com dosagem regular de flúor (grupo b). Desta forma, o flúor administrado, tanto durante quanto antes da prenhez, parecem influenciar no nível de flúor nos incisivos, entretanto, o acúmulo parece ser maior quando a sua administração ocorre durante a prenhez.

Por outro lado, ainda deve ser estudado melhor a capacidade do flúor presente no leite materno ser absorvido, uma vez que a inclusão suplementar de cálcio na dieta poderia certamente reduzir a absorção de flúor em alguma extensão do tubo digestório e aumentar a sua excreção nas fezes (WHITFORD ${ }^{183}$, 1994).

Entretanto, ERICSSON ${ }^{58}, 1958$, analisando amostras de leite fluoretado, sugeriu que o flúor presente seja relativamente estável, ocorrendo apenas uma quantidade limitada de ligação do flúor com constituintes orgânicos. Além disso, demonstrou que embora o nível inicial de absorção de flúor no rato seja menor quando administrado no leite, o seu nível sangüíneo permanece por um período maior do que quando é fornecido na água de beber.

A biodisponibilidade do flúor no leite também foi estudada por VILLA et al. ${ }^{177}$, 1989. Utilizaram ratos desmamados divididos em grupos que receberam uma dieta sólida balanceada especialmente preparada com baixo conteúdo de flúor (menos de $1 \mu \mathrm{g} / \mathrm{g}$ ) e 10ppm de monofluorofosfato de sódio (MFP) preparado em leite em pó ou 10ppm de NaF na água de abastecimento ou na água destilada ou no chá. Os animais foram sacrificados após três semanas e os fêmures foram removidos para análise. Não foram observadas diferenças entre a concentração de flúor nos fêmures de animais que receberam MFP no leite em pó preparado, NaF na água de abastecimento ou na água destilada, entretanto houve uma redução nas concentrações de flúor nos ossos de animais que receberam NaF no chá.

Numa segunda parte desta pesquisa, crianças pré-escolares (entre 3 e 5 anos) que receberam $1 \mathrm{mg}$ de flúor em tabletes de NaF e após uma semana receberam 1,18mg de MFP em leite em pó preparado com água de abastecimento. Num primeiro momento, as crianças receberam flúor cinco minutos antes do almoço. Num segundo momento, as mesmas crianças 
receberam flúor após um jejum de dez horas, não sendo permitidas de alimentar-se até três horas após a ingestão. A água de beber possuía uma concentração de flúor de $0,18 \mathrm{ppm}$. Foi verificada então a excreção de flúor na urina a cada 24 horas. Os resultados sugeriram que a absorção de flúor (analisada pela sua excreção renal) na forma de MFP no leite preparado é tão alto quanto do $\mathrm{NaF}$ na água de beber quando ingeridos em jejum, porém a biodisponibilidade do flúor no leite diminuiu quando a ingestão ocorreu simultaneamente ao consumo de alimentos.

Porém, quando se refere ao efeito protetor contra as cáries, parece não existir diferenças entre a utilização do flúor adicionado ao leite ou à água de beber (POULSEN, LARSEN, LARSON ${ }^{136}, 1976$ ).

Em termos de saúde pública e prevenção da fluorose, deve-se lembrar que a quantidade de flúor presente no leite materno é menor que o presente em alimentos derivados do leite de vaca. ADAIR e $\mathrm{WEI}^{1}$, 1978, analisaram a quantidade de flúor presente em amostras de leite materno de duas mães que residiam em Iowa em áreas onde a fluoretação na água de abastecimento é de $1,0 \mathrm{mgF} / \mathrm{kg}$, utilizando um eletrodo específico para o íon flúor. Foram obtidos valores de 0,016 e $0,015 \mu \mathrm{g} / \mathrm{mL}$ para a dosagem de flúor iônico livre. A quantidade de flúor total foi menor que $0,10 \mu \mathrm{g} / \mathrm{mL}$ para as duas amostras. Neste trabalho, também foi verificado que a quantidade de flúor das amostras de leite materno humano foi menor que a presente em produtos derivados do leite de vaca. Isto significa que a ingestão de flúor é menor quando a criança recebe leite materno ao invés de outras preparações alimentares.

De forma geral, verifica-se uma limitação nas informações obtidas na literatura a respeito dos efeitos clínicos da fluoretação no leite, da capacidade de absorção do flúor ingerido no leite materno, da secreção do flúor no leite materno, da importância do flúor presente no leite materno na patogenia da fluorose; sendo assim, mais estudos devem ser realizados nesta área para que se entenda melhor a importância do flúor no leite materno e no leite fluoretado na patogênese da fluorose especialmente em dentes decíduos. 
Assim, após a análise desses trabalhos, percebe-se que o nível de flúor no leite materno está diretamente relacionado com:

- A quantidade de flúor presente na água ingerida pela mãe antes e durante a gravidez e durante o período de amamentação;

- O tempo em que o feto ou a criança foram expostos ao flúor;

- A dieta da mãe antes e durante a gravidez e durante a amamentação;

Conclui-se também que, apesar do flúor estar presente no leite materno, a glândula mamária, assim como a placenta, atua como uma barreira seletiva, diminuindo a sua concentração. Por outro lado, no rato, a glândula mamária parece concentrar o flúor no leite, promovendo uma maior acúmulo no filhote. 


\subsection{Os efeitos do flúor sobre o esmalte dentário}

Existe uma série de eventos que ocorrem durante o desenvolvimento do esmalte dentário nos quais o flúor pode ter algum efeito:

1. Proliferação celular

2. Diferenciação e morfologia celular

3. Função celular

a. Síntese e secreção da matriz orgânica

a1. Amelogeninas

a2. Proteínas não amelogeninas

b. Deposição da matriz inorgânica

b1. Iniciação

b2. Crescimento do cristal

b3. Propriedades bioquímicas

C. Maturação do esmalte

c1. Processamento e remoção de proteínas e perda de água

Estabeleceram-se algumas hipóteses sobre a patogenia da fluorose, das quais foram propostos três mecanismos que poderiam alterar a produção, a degradação e a remoção das proteínas da matriz. O primeiro diz respeito à interferência na diferenciação ou na perda funcional dos ameloblastos que afetariam diretamente suas propriedades de secreção e reabsorção (DENBESTEN; CRESHAW; WILSON ${ }^{48}$, 1985; HOLLAND; HONGSLO ${ }^{78}$, 1979). O segundo indica que o fluoreto incorporado à estrutura do cristal de apatita promove uma união mais estável entre a matriz inorgânica e a orgânica, tornando a clivagem das proteínas menos acessível, uma função executada pelas enzimas presentes no esmalte (TAN et al. ${ }^{170}$, 1998; TANABE et al. ${ }^{171}$, 1988). E um outro mecanismo está vinculado à inibição da atividade proteolítica das enzimas destinadas à degradação da matriz, como as metaloproteínases e 
a calicreína 4 (AOBA; FEJERSKOV ${ }^{6}$, 2002; DENBESTEN; THARIANI ${ }^{47}$, 1992; DENBESTEN et al. $^{49}$, 1992; DENBESTEN et al. ${ }^{50}$, 2002; FUKAE et al. ${ }^{69}$, 1998; GERLACH et al. ${ }^{75}$, 2000; LIMEBACK $^{105}$, 1994).

A fundamentação dessas três hipóteses relativas à patogenia da fluorose dentária tem uma característica comum, concorda-se que a porção protéica da matriz fica retida após o início da fase de maturação do esmalte, momento em que deveriam ser removidas paulatinamente até serem quase totalmente endocitadas pelos mesmos ameloblastos que as produziram e secretaram (DENBESTEN; CRENSHAW; WILSON ${ }^{48}$, 1985; NANCI et al. ${ }^{122}$, 1998).

O flúor apresenta a capacidade de ligar-se não apenas aos cristais de apatita, mas também a proteínas da matriz do esmalte (CRENSHAW; BAWDEN $^{34}$, 1981; CRENSHAW; WENNBERG; BAWDEN ${ }^{35}$, 1978). Os efeitos do flúor parecem estar relacionados à fase de produção ou maturação do esmalte, pois o flúor poderia estar ligado à matriz orgânica, ou mais especificamente às proteínas da matriz orgânica sendo, por isso, encontrado em maior concentração no esmalte jovem (CRENSHAW; WENNBERG; BAWDEN ${ }^{35}$, 1978).

A ligação de íons como o flúor no esmalte em desenvolvimento parece depender também da porosidade e do estado de hidratação do tecido. Devido a este fato, o esmalte jovem que é um tecido mais hidratado que o esmalte maduro contém, então, maior concentração de flúor principalmente na forma de íons livres em solução. Posteriormente, o flúor presente no esmalte jovem, ligado à matriz orgânica ou na forma iônica, seria perdido, durante a fase de maturação do esmalte, que é caracterizada pela deposição mineral com perda de proteínas e água (ROBINSON; KIRKHAM; HALLSWORTH ${ }^{144}$, 1988).

Sabe-se também que a substituição da hidroxila por fluoreto nos cristais de apatita pode elevar a adsorção das proteínas do esmalte. Como a fluorapatita desloca mais água que a hidroxiapatita, as moléculas hidrofílicas de amelogeninas e seus produtos teriam sua interação com essa superfície aumentada, sendo necessária menos energia para a adsorção de proteínas. Estes resultados sugerem que a retenção das proteínas da matriz no esmalte em desenvolvimento poderia ser afetada pela natureza dos cristais formados. Esses eventos poderiam afetar a degradação enzimática das amelogeninas 
durante o processo de fluorose, contribuindo com um retardo na remoção das proteínas do esmalte (AOBA et al. ${ }^{7}, 1990$; TANABE et al. ${ }^{171}$, 1988).

Existem muitas controvérsias a respeito dos possíveis efeitos do flúor sobre o processo de mineralização. Vários autores acreditam que ocorram as alterações na seqüência de aminoácidos das proteínas constituintes da matriz do esmalte, que pode ser responsável pelo quadro de fluorose dental. Isto levaria a alterações na matriz orgânica o que impediria ou dificultaria a degradação enzimática das proteínas do esmalte, impedindo ou dificultando a mineralização (BASFORD; PATTERSON; KRUGER ${ }^{14}$, 1976; DENBESTEN ${ }^{41}$, 1986; DENBESTEN; CRENSHAW ${ }^{44}$, 1984; DRINKARD; CRENSHAW; BAWDEN ${ }^{53}$, 1983; KRUGER $^{96}$, 1970; KRUGER ${ }^{97}$, 1972; PATTERSON; BASFORD; KRUGER ${ }^{133}$, 1976).

Considerando esta teoria, o esmalte fluorótico apresentaria uma maior concentração do conteúdo orgânico, por maior retenção do mesmo (AOBA et al. ${ }^{8}$, 1987; SHINODA ${ }^{151}$, 1975), uma menor concentração do conteúdo mineral, caracterizando uma hipomineralização (AOBA et al. ${ }^{8}$, 1987; DENBESTEN; CRENSHAW $^{44}$, 1984; SHINODA ${ }^{151}$, 1975) e alteração na composição da matriz protéica (DENBESTEN; CRENSHAW ${ }^{44}$, 1984; PATTERSON; BASFORD; $K_{R U G E R}{ }^{133}$, 1976). Entretanto, estudos subseqüentes sugeriam não existir diferenças na qualidade protéica da matriz de esmalte produzida por animais expostos ou não ao flúor (AOBA et al. ${ }^{7}, 1990 ;$ DENBESTEN ${ }^{41}$, 1986).

Uma outra possibilidade para explicar os efeitos do flúor sobre o esmalte está na teoria em que a ligação do flúor à matriz extracelular do esmalte dificulte a digestão enzimática por proteinases (AOBA ${ }^{4}, 1994$; DENBESTEN et al. $^{49}$, 1992; HEFFERMAN; DENBESTEN ${ }^{77}$, 1991). Isto causaria um atraso na degradação da matriz do esmalte, ao invés de uma alteração nas proteínas que são inicialmente secretadas (DENBESTEN $\left.{ }^{41}, 1986\right)$.

Um fato interessante a ser observado é que o comprimento da matriz na região pós-secretora (em maturação) é maior em grupos com fluorose (causadas pela administração de 75 e 100ppm em ratos no período de seis semanas), que em animais que não recebem fluoretos em sua alimentação. Este fato parece ser uma confirmação morfológica do atraso da degradação e 
reabsorção das proteínas de matriz, causando hipomineralização (ZHOU; ZAKI; EISENMANN ${ }^{185}$, 1996).

Desta forma, o retardo da remoção protéica parece ser um dos efeitos do flúor sobre a matriz de esmalte. DENBESTEN ${ }^{41}$, 1986, realizou um estudo utilizando ratos submetidos a doses de 10, 25, 50 e 100ppm de NaF na água de beber durante cinco semanas, utilizando-se a eletroforese e a cromatografia. Foi verificado em animais que receberam $25 \mathrm{ppm}$ de flúor ou mais (o correspondente a 0,05ppm de flúor plasmático ou mais) apresentavam um atraso na clivagem enzimática de todas as isoformas de proteínas durante a fase de maturação. Por outro lado, apenas quando os animais recebiam mais de 100ppm de flúor, ocorria uma maior retenção de proteínas no esmalte. Ou seja, nos grupos de 25 e 50ppm, embora houvesse um retardo na remoção das proteínas, estas eram removidas por completo na fase de maturação. Ficou claro então que os altos níveis de flúor podem retardar os mecanismos de remoção das proteínas do esmalte e que este efeito é dose-dependente.

A alteração na atividade proteolítica por ingestão de flúor num prazo prolongado parece também ser um importante mecanismo na formação do esmalte fluorótico (DENBESTEN; HEFFERNAN ${ }^{46}$, 1989). Acredita-se na possibilidade de uma interferência direta do flúor na atividade extracelular das proteinases $\left(\mathrm{AOBA}^{4}\right.$, 1994; $\mathrm{AOBA}^{5}$, 1997; BAWDEN; DEATON; CRENSHAW ${ }^{15}$, 1987; DENBESTEN; HEFFERNAN ${ }^{46}$ ，1989; LIMEBACK ${ }^{105}$ ，1994; RICHARDS ${ }^{141}$, 1990), necessárias para degradar as amelogeninas durante a maturação do esmalte $\left(\right.$ AOBA $^{4}$, 1994; OVERALL; LIMEBACK ${ }^{130}$, 1988), ou na formação da fluorapatita, dificultando a ação das proteinases. Desta forma, o flúor poderia ter um efeito direto na atividade enzimática de proteases e conseqüentemente causaria um atraso na remoção das proteínas do esmalte (AOBA et al. ${ }^{7}$, 1990; LIMEBACK $^{105}$, 1994; MONSOUR; KRUGER; SMID ${ }^{115}$, 1985; RICHARDS ${ }^{141}$, 1990; ROBINSON; KIRKHAM ${ }^{142}$, 1990; TANABE et al. ${ }^{171}$, 1988), uma vez que concentrações micromolares de flúor podem alterar a atividade das metaloproteinases, como por exemplo, a metaloproteinase-20 (MMP-20 ou enamelisina), particularmente quando o pH é reduzido a 6,0 . Sendo assim, é 
possível que o flúor esteja envolvido com a secreção ou atividade da proteinase durante a patogênese da fluorose (DENBESTEN et al. ${ }^{50}$, 2002).

Uma possível explicação para a redução na atividade da MMP-20 na presença de flúor num pH reduzido é a capacidade dos íons flúor em ligar-se a três resíduos de histidina localizados em sítios altamente conservados de ligação ao zinco das metaloproteinases (incluindo a MMP-20) (BIRKEDALHANSEN et al. ${ }^{18}$, 1993). Os íons flúor altamente eletronegativos poderiam ligarse mais rapidamente à histidina pelos íons hidrogênio, quando o pH é diminuído e poderia interferir na ligação do metal necessário para a atividade enzimática (DENBESTEN et al. ${ }^{50}$, 2002).

Alguns trabalhos sugerem que o flúor seja capaz de inibir também a calicreína 4 a qual apresenta-se ativa apenas no esmalte em maturação (LIMEBACK $^{105}$, 1994; OVERALL; LIMEBACK ${ }^{130}$, 1988). Por outro lado, a quantidade de flúor necessária para inibir a digestão da amelogenina é desconhecida (LIMEBACK ${ }^{105}$, 1994).

O flúor parece ter ação também sobre as enzimas lisossomais. Deve-se lembrar que uma significante quantidade de proteinas do esmalte é removida por endocitose, envolvendo as enzimas lisossomais. Estas parecem ser inibidas por altas concentrações de flúor (LIMEBACK ${ }^{105}$, 1994).

A ação do flúor foi verificada avaliando-se a dipeptil peptidase II, uma exopeptidase lisossomal que tem sido adotada como um marcador para lisossomas em estudos citoquímicos. SMID et al. ${ }^{160}$ em 1990, utilizaram ratas de 21 dias de idade que receberam injeções intraperitoneais de 10 e $20 \mathrm{mg}$ de $\mathrm{NaF} / \mathrm{kg}$ de peso corporal duas vezes por dia durante quatro dias consecutivos e uma vez no quinto dia. Foi observada uma menor marcação da dipeptidil peptidase II em ameloblastos secretores e em modulação de incisivos inferiores que no grupo que não recebeu flúor. Este dado sugere que um dos mecanismos envolvidos na fluorose também possa ser a inibição da atividade de enzimas lisossomais proteolíticas de ameloblastos. 


\section{4 Os efeitos do flúor sobre os ameloblastos}

\subsubsection{Alterações morfológicas em ameloblastos causadas pelo flúor}

Poucos são os estudos na literatura que descrevem especificamente as alterações morfológicas ultraestruturais de ameloblastos causadas pela administração de flúor. De forma geral, tanto as dosagens crônicas como as agudas de flúor provocam alterações na ultraestrutura de ameloblastos de dentes de ratos adultos, como a atrofia da porção distal, mitocôndrias dilatadas, distensão bem como acúmulo de material de secreção no retículo endoplasmático (KRUGER ${ }^{94}$, 1968; RIBEIRO; ASSIS; HIROTA ${ }^{140}$, 2001), maior acúmulo de vacúolos claros (KRUGER ${ }^{94}, 1968$; OLIVEIRA ${ }^{128}$, 1988; WALTON; EISENMANN ${ }^{178}$, 1974) e corpos escuros no citoplasma, além do acúmulo de grânulos de secreção na região apical, processo de Tomes fragmentado ou reduzido e desorganização do aspecto colunar das células (LYARUU et al. ${ }^{107}$, 1986; WALTON; EISENMANN ${ }^{178}$, 1974).

A utilização de uma dose única de flúor administrada por injeção subcutânea em ratos adultos pode provocar distúrbios intracelulares na via de síntese-secreção do ameloblasto (MATSUO; KIYOMIYA; KUREBE ${ }^{111}$, 1998; MATSUO et al. ${ }^{112}$, 1996), formação de uma matriz do esmalte hipomineralizada (MATSUO et al. ${ }^{112}$, 1996; NEIMAN; EISENMANN ${ }^{123}$, 1975; NORDLUND; EKSTRAND; HAMMARSTRÖM ${ }^{126}$, 1986; SIMMELINK; LANGE $^{154}$, 1986), e degenerações císticas na região subameloblástica (NORDLUND; LINDSKOG $^{125}$, 1986; NORDLUND; EKSTRAND; HAMMARSTRÖM ${ }^{126}$ ， 1986; SIMMELINK; LANGE $\left.^{154}, 1986\right)$.

Uma série de estudos foi realizada em microscopia eletrônica de transmissão utilizando o flúor em uma alta dosagem aplicada por múltiplas injeções intraperitoneais. Em 1967, KRUGER ${ }^{93}$ analisou os efeitos da injeção intraperitoneal de $7 \mathrm{mgNaF} / \mathrm{kg}$ de massa corporal em incisivos e molares de ratos Osborne-Mendel de diferentes idades divididos nos seguintes grupos: 1) 
primeira série: receberam duas injeções diárias no $4^{\circ}, 5^{\circ}$ e $6^{\circ}$ dia de vida pósnatal; 2) segunda série: receberam duas injeções diárias no $6^{\circ}, 7^{\circ}, 8^{\circ} 9^{\circ}$ dia de vida pós-natal e uma injeção diária no $10^{\circ}$ e $13^{\circ}$ dia; 3) terceira série: receberam duas injeções diárias no $8^{\circ}, 9^{\circ}, 10^{\circ}$ e $11^{\circ}$ dia de vida pós-natal e uma injeção diária no $12^{\circ}$ dia. Foi verificado que em molares, dois tipos de glóbulos apareciam na região distal do citoplasma de ameloblastos: vacúolos claros com mais de $10 \mu \mathrm{m}$ de diâmetro e pequenos glóbulos escuros de 3 a $6 \mu \mathrm{m}$. Os glóbulos escuros eram também vistos próximos à região basal e no estrato intermediário, porém não foram visualizados em animais do grupo controle. Nos animais que receberam tratamento, grandes vacúolos claros eram vistos na região distal do citoplasma em diferentes posições e tamanhos que os observados normalmente no início da maturação, os quais estavam localizados mais na região distal dos ameloblastos e apresentavam diâmetros aproximado de 3 a $5 \mu \mathrm{m}$. Os autores sugeriram ainda que vacúolos claros apresentavam aspectos semelhantes aos observados em células que sofriam degeneração hidrópica.

Posteriormente, analisando ameloblastos secretores em utilizando microscopia eletrônica de transmissão, em 1968, KRUGER ${ }^{94}$ analisou o germe dental do primeiro molar de ratos após três injeções intraperitoneais de $7 \mathrm{mgNaF} / \mathrm{kg}$ aplicadas diariamente em diferentes períodos do $4^{\circ}$ e $5^{\circ}$ dia de vida pós-natal. Os ameloblastos secretores apresentavam distensões vacuolares do retículo endoplasmático e dilatação das mitocôndrias com desaparecimento das cristas.

Em 1970, KRUGER ${ }^{96}$ descreveu alterações morfológicas em ameloblastos de incisivos de ratos, desta vez causadas por uma única injeção intraperitoneal de flúor. Nesta pesquisa, foram utilizados ratos Osborne-Mende/ de quatro dias de vida que receberam uma única injeção intraperitoneal de $0,1,3$ ou $7 \mathrm{mgNaF} / \mathrm{kg}$ de massa corporal. Estes animais foram decapitados 30, 60 e 90 minutos após a injeção. Observou que uma dose única de $0,1 \mathrm{mgNaF} / \mathrm{kg}$ não alterava a ultraestrutura dos ameloblastos. A dose de $3 \mathrm{mgNaF} / \mathrm{kg}$ induzia a dilatação das cisterna do retículo endoplasmático depois de 30 minutos após a injeção, sendo que este aspecto permanecia nos animais sacrificados após 60 e 
90 minutos. Quando os animais recebiam $7 \mathrm{mgNaF} / \mathrm{kg}$ observavam-se amplas áreas de dilatações de retículo endoplasmático, sendo estas regiões livres de ribossomas. Desta forma, a dose de $0,1 \mathrm{mgNaF} / \mathrm{kg}$ de massa corporal foi considerada como dose limítrofe na promoção de fluorose (sendo essa quantidade consideravelmente mais alta que os $0,04 \mathrm{mgNaF} / \mathrm{kg}$ capazes de causar fluorose em humanos). Esta dose é capaz de causar alterações compatíveis com fluorose dentária, sem provocar alterações ultraestruturais em ameloblastos.

Num estudo subseqüente, WALTON; EISENMANN ${ }^{178}$, 1974, utilizaram incisivos de ratos que receberam duas injeções peritoneais diárias de $\mathrm{NaF}$ a $2,5 \%(17 \mathrm{mg} / \mathrm{kg})$ durante quatro dias. Na manhã do quinto dia, a injeção final era ministrada e o animal era sacrificado três horas depois. Foram observadas alterações no terço distal do corpo celular e no processo de Tomes de ameloblastos secretores. Vacúolos claros que pareciam empilhados na célula e grupos de corpos escuros ambos com tamanhos e densidades variados ocupavam especialmente o terço distal da célula. Ocasionalmente, grandes vacúolos de formatos irregulares continham material pontilhado esparso localizado próximo à rede terminal distal da célula. 0 processo de Tomes apresentava-se fragmentado em sua extremidade. No corpo celular, eram observados corpos esféricos, os quais apresentavam gradiente de variação em tamanho e densidade, um diâmetro que geralmente estendia-se quase a toda largura das células e uma tendência em deslocar organelas, particularmente 0 retículo endoplasmático. Os corpos eram discretos e não se comunicavam entre si, nem com organelas ou inclusões. O aparelho de Golgi localizava-se próximo aos corpos esféricos e parecia não ser afetado pelo flúor. $\mathrm{Na}$ fase de maturação, os ameloblastos apresentavam vacúolos de diferentes tamanhos e contornos. As células variavam de um formato normal até aquelas com grandes vacúolos que deslocavam a membrana celular, o núcleo e organelas. Os vacúolos revestidos por membrana estavam preenchidos por um material pontilhado difuso e geralmente contidos dentro de uma membrana circular formando um vacúolo dentro de um vacúolo. Freqüentemente, continham corpos granulares escuros que tendiam a localizar-se próximos à superfície 
interna da membrana. Quanto mais distantes do esmalte os vacúolos estavam localizados, maior era o tamanho deles. A extremidade distal dos ameloblastos em maturação adaptava-se e interdigitava-se na superfície irregular do esmalte.

As alterações em ameloblastos também foram estudadas por NEIMAN; EISENMANN ${ }^{123}$, 1975, num estudo utilizando injeção subcutânea de $5 \mathrm{mg}$ de $\mathrm{NaF}$ em dose única em ratos Sprague-Dawley machos com peso corporal de 175-250g que foram sacrificados após 1, 2, 4, 8, 16, 24 e 48 horas. Alterações morfológicas apareceram apenas duas horas após a injeção quando numerosos vacúolos enormes e glóbulos escuros pareciam empilhar-se na metade distal do corpo celular. Estes corpos esféricos variavam em tamanho e densidade, estendendo-se por toda largura da célula e deslocando cisternas de retículo endoplasmático. Estavam envolvidos por membrana e pareciam não se comunicar entre si ou com qualquer outra organela. As organelas do corpo celular eram de aparência normal e a quantidade de grânulos de secreção era similar a do grupo controle. Nenhuma alteração foi observada no processo de Tomes. Após quatro horas, os corpos escuros e os vacúolos aumentavam em número e em alguns casos estendiam-se na região nuclear. Pequenos grupos de material pontilhado acumulavam-se fora da porção distal do processo de Tomes. A aparência geral dos demais componentes da célula e do processo de Tomes apresentavam-se inalterados. Após oito horas, grandes áreas de material puntiforme estavam presentes na região distal do processo de Tomes. Havia uma diminuição na formação de esmalte entre os processos. Os grandes corpos, observados anteriomente, apresentavam-se reduzidos em número e em tamanho. Após 16 horas, os corpos escuros e vacúolos, observados na região central dos ameloblastos, eram semelhantes em tamanho e quantidades àqueles observados no grupo controle. Nenhuma alteração era observada nas organelas, mas a morfologia e tamanho do processo de Tomes estava alterado. A formação de esmalte estava reduzida entre os processos de Tomes e na região distal de cada processo, deixando para trás grandes áreas de material pontilhado não ou pouco cristalizado. Após 24 a 48 horas, observa-se a continuação das alterações observadas no processo de Tomes e o esmalte normal é depositado sobre uma banda hipomineralizada. 
MÖRNSTAD; HAMMARSTRÖM ${ }^{117}$, 1978, verificaram os efeitos do flúor sobre o órgão do esmalte em ratos Sprague-Dawley de ambos os sexos de 2 a 12 dias de idade que receberam injeção intraperitoneal de $0,01 \mathrm{~mL} / \mathrm{g}$ de peso corporal da solução aquosa de $\mathrm{NaF}$ a $0,6 \%$. Os animais foram sacrificados 1, 2, $3,6,8,24,48$ ou 72 horas após a injeção. Alterações celulares foram observadas em molares, mas não foram observadas nos germes dentários de incisivos. A alteração mais proeminente observada nos períodos de uma e duas horas após a injeção foi uma marcada vacuolização no citoplasma de ameloblastos secretores. Mitocôndrias inchadas e rompidas eram proeminentes em toda célula, mas principalmente próximo ao núcleo, próximo à região distal ao núcleo e na maior parte da região distal das células. Foram observadas uma severa desintegração e degranulação da superfície do retículo endoplasmático rugoso e de polirribossomos. Estas injúrias intracelulares eram geralmente associadas à separação dos ameloblastos da matriz do esmalte. A formação destas fendas separando a célula da matriz aparecia apenas em locais onde 0 ameloblasto exibia alterações celulares pronunciadas. No citoplasma de alguns ameloblastos secretores sem vacuolização havia grupos de glóbulos muito corados de diâmetro de cerca de $10 \mu \mathrm{m}$ de três tipos: um fortemente elétrondenso sem revestimento de membrana, outro elétron-denso revestido por membrana e um terceiro de menor densidade limitado por membrana. Duas horas após a injeção de flúor, os ameloblastos secretores mostraram as mesmas alterações observadas uma hora após a injeção de flúor. Nos períodos de três e seis horas após a injeção, além das características morfológicas observadas, grupos de ameloblastos eram reduzidos em tamanho, enquanto algumas células adjacentes mantinham a altura normal e formavam estruturas semelhantes a bulbos projetando na fenda que separava as células. Oito horas após a injeção, as estruturas semelhantes a bulbos eram mais proeminentes, mas havendo também áreas de separações entre as células não associadas às estruturas semelhantes a bulbos. Após 24 horas, as formações semelhantes a bulbos situavam-se longe da matriz do esmalte, sendo constituídos por células que perdiam a orientação regular. Entre os ameloblastos lesionados e a matriz de esmalte havia cavidades semelhantes a cistos preenchidas por material 
vacuolar. A matriz de esmalte debaixo destas cavidades apresentava uma superfície irregular e era geralmente coberta por material puntiforme em forma de gotas pequenas, arredondadas e escuras. Após 48 horas, as células desarranjadas se deslocavam para longe da matriz do esmalte, mas esta permanecia em contato com os ameloblastos normais adjacentes. Nas regiões centrais das cavidades semelhantes a cistos foram identificadas estruturas pequenas, arredondadas e fortemente coradas. Após 72 horas, grupos de ameloblastos apareciam como ilhas isoladas no retículo estrelado, entretanto, sempre demonstrando conexão com células que rodeavam as cavidades císticas. Os resultados sugeriram que os ameloblastos secretores eram mais sensíveis que as células pós-secretoras e que o órgão do esmalte de molares era mais sensível que o de incisivos.

Em 1980, FEJERSKOV et al. ${ }^{63}$ realizaram um estudo com objetivo de examinar os efeitos da exposição crônica do flúor na amelogênese. Foram utilizado três grupos de ratos que receberam 0,56,5 e 113ppm de flúor na água de beber do $30^{\circ}$ ao $90^{\circ}$ dia de vida. Foram observados grânulos densos pequenos na região proximal do processo de Tomes de ameloblastos secretores, mas que não apresentavam alterações patológicas.

NORDLUND et al. ${ }^{127}, 1986$, analisaram por microscopia eletrônica de transmissão ameloblastos secretores de primeiro molar superior de ratos Sprague-Dawley que receberam uma injeção subcutânea única de $60 \mathrm{mgNaF} / \mathrm{kg}$ de peso corporal. Foi observada a formação de uma luz cística, delineada, de um lado por uma parede de ameloblastos desarranjados e, do outro por um esmalte em desenvolvimento. Os ameloblastos da parede cística apresentavam vários graus de alterações citoplasmáticas e nucleares. As alterações citoplasmáticas eram evidentes em todas células que circundavam a luz cística. Algumas células apresentavam sinais de necrose, indicada pela condensação da cromatina em combinação com as alterações degenerativas do citoplasma como a distensão do retículo endoplasmático, das vesículas de complexo de Golgi e a fragmentação citoplasmática. Várias células de formatos arredondados ou irregulares perdiam contato com o estrato intermediário e estavam deslocadas em direção da luz cística. Esta apresentava material floculento elétron-lúcido e 
células inteiras com extensas alterações nucleares e citoplasmáticas, fragmentos celulares, aparentemente oriundos da camada ameloblástica. Alguns ameloblastos apresentavam atividade fagocítica indicada por vacúolos contendo fragmentos celulares e material extracelular. Produtos de secreção eram observados no meio extracelular entre os ameloblastos e entre as células do estrato intermediário. As maiores alterações citoplasmáticas foram observadas na região distal dos ameloblastos que recobriam a luz cística. Os processos de Tomes desaparecem e surgem indentações e protusões de membrana plasmática. A presença de fragmentos citoplasmáticos na luz cística sugere que o citoplasma tenha sido perdido antes e que parte das protusões representavam justamente esta perda. Além disso, nas células próximas à luz, esta perda era, algumas vezes, tão grande que as células remanescentes consistiam apenas de um núcleo envolvido por uma margem muito pequena de citoplasma. $\mathrm{O}$ desaparecimento do processo de Tomes parece estar relacionado à perda de adesão dos ameloblastos à matriz do esmalte. As alterações no retículo endoplasmático e complexo de Golgi podiam ser observadas na maioria das células da parede cística mais severamente afetada e nas células presentes na luz cística. Em algumas áreas, as cisternas de ambas organelas apresentavam-se dilatadas, possivelmente devido à retenção de produto de secreção, indicados por seu conteúdo densamente corado. Os grânulos de secreção eram observados espalhados por toda periferia citoplasmática e fusionando-se à membrana plasmática. Grandes vacúolos ocasionalmente continham um material cristalino ou granular cuja composição era desconhecida. Em alguns ameloblastos severamente afetados na luz, as mitocôndrias apresentavam-se dilatadas e sofriam lise. O núcleo dos ameloblastos da parede cística estava localizado proximalmente ou centralmente. Alterações nucleares, como a concentração de cromatina e fragmentação da carioteca, eram apenas notadas em células que apresentavam maiores alterações citoplasmáticas ou deslocamento nuclear. Todas estas alterações degenerativas parecem ser semelhantes ao padrão característico de degeneração celular. 
OLIVEIRA $^{128}$ em 1988 estudou por microscopia óptica ameloblastos secretores de incisivos de ratos que receberam injeções intraperitoneais de 0,06, 0,12 e 4,0mgF/kg na forma de solução de NaF durante 45 dias. Um maior número de vacúolos claros no citoplasma dos ameloblastos secretores e um espaço rendilhado no processo de Tomes foram visíveis nos grupos experimentais, quando comparados ao controle.

Outras alterações ultraestruturais em ameloblastos de ratos que receberam uma dose intraperitoneal única de flúor também foram relatadas por MONSOUR; HARBROW; WARSHAWSKY ${ }^{114}$, 1989. Nesta pesquisa, estes autores estudaram os efeitos causados pela injeção intravenosa na veia femural de 10 ou $20 \mathrm{mgNaF} / \mathrm{kg}$ de peso corporal em ratos machos Wistar que foram sacrificados 40, 90, 180 minutos e 24 horas após a administração. Utilizando microscopia eletrônica de transmissão, foi observado que as alterações morfológicas na região proximal dos ameloblastos secretores eram mínimas. $\mathrm{Na}$ região supranuclear, houve um aumento de vários tipos de grânulos próximos à região do complexo de Golgi. Foi observado também um aumento de material pontilhado próximo aos cristais de esmalte na porção de interdigitações do processo de Tomes e acúmulos deste material eram encontrados entre as porções proximais. Os resultados demonstraram que a injeção aguda de flúor interferiu na função normal dos ameloblastos secretores, causando alteração na síntese do esmalte.

PERGOLIZZI et al. ${ }^{134}$ (1995) estudaram incisivos inferiores de ratos albinos com peso médio de $150 \mathrm{~g}$ os quais receberam aproximadamente $35 \mathrm{ppm}$ de flúor na água de beber durante 60 dias. Neste trabalho, os ameloblastos secretores mostraram REG bastante evidente e perda de grânulos densos. Em relação à fase de maturação, foi observado que os efeitos do flúor ocorrem especialmente em ameloblastos de terminação lisa, em detrimento ao de terminação rugosa; havendo um decréscimo da secreção de enzimas lisossômicas e, como conseqüência, uma redução na reabsorção de matriz orgânica. Além disso, foram observados danos às mitocôndrias, o que poderia ser sugestivo de uma redução na captação de cálcio por um déficit na atividade 
energética, podendo justificar a redução na mineralização do esmalte causada pelo flúor em ameloblastos.

As alterações ultraestruturais observadas em ameloblastos secretores utilizando técnicas imuno-histoquímicas foram relatadas por MATSUO et al. ${ }^{112}$, 1996. Neste trabalho, os autores utilizaram anticorpos contra amelogenina pela técnica do ouro coloidal numa diluição não informada para avaliar ratos Wistar de oito semanas de vida que receberam injeções subcutâneas de $20 \mathrm{mgF} / \mathrm{kg}$ a partir de uma solução de $\mathrm{NaF}$ a $1,25 \%$ durante quatro dias. No grupo controle, o qual não recebeu flúor, a deposição de partículas de ouro foi observada no retículo endoplasmático rugoso, complexo de Golgi e vacúolos de condensação. Intensa deposição também foi observada na camada de esmalte. Nos ameloblastos secretores dos animais tratados com $\mathrm{NaF}$, as partículas de ouro eram observadas em grandes grânulos formados anormalmente, assim como no retículo endoplasmático rugoso, complexo de Golgi e esmalte. A quantidade de partículas dentro dos grandes grânulos diferia entre eles de acordo com a propriedade de seu conteúdo. A maior marcação era observada em grandes grânulos de baixa densidade contendo conteúdo de granulação fina. 0 conteúdo destes grânulos lembrava aqueles dos grânulos de secreção em relação à sua elétron-densidade. Por outro lado, grandes grânulos de granulação grosseira exibiam marcação fraca ou ausente. Os grânulos estavam geralmente fusionados uns aos outros. Além disso, os grânulos ocasionalmente continham dois tipos de conteúdo: um conteúdo de baixa elétron-densidade na zona central dos grânulos e um conteúdo altamente elétron-denso na periferia do grânulo. Apenas a zona central dos grânulos era marcada por partículas de ouro. Em alguns destes grânulos, as zonas periféricas e central não estavam claramente delimitadas. $\mathrm{Na}$ análise ultraestrutural deste estudo foram observados grandes grânulos formados anormalmente e acumulados na região distal do citoplasma. Estes exibiam diferentes densidades e seu conteúdo variava de um material granular fino a grosseiro. Alguns grandes grânulos continham pequenas vesículas, as quais variavam de número em cada grânulo. Estes grandes grânulos eram freqüentemente unidos ao longo eixo da célula e ocasionalmente fusionados uns aos outros. Pequenas vesículas também se 
acumulavam formando grupos no citoplasma, sendo estes observados próximo ao complexo de Golgi, grandes grânulos e entre os sáculos do retículo endoplasmático rugoso. A exposição ao flúor induziu alterações morfológicas no complexo de Golgi, como a substituição de grupos de pequenas vesículas por sáculos. Ocasionalmente, uma pilha do complexo de Golgi era substituída por um grupo de pequenas vesículas e grânulos. Pilhas de complexo de Golgi fragmentadas eram também observadas entre acúmulos de grânulos. Além disso, os sáculos do complexo de Golgi estavam eventualmente dilatados em cada compartimento do complexo de Golgi. Em alguns casos, os sáculos da face cis estavam dilatados e em outros os presentes na região medial ou face trans. O acúmulo de grandes grânulos anormais e a dilatação dos sáculos do complexo de Golgi com o tratamento de flúor parece indicar alterações na formação e arranjo de vesículas secretoras. Estes resultados sugerem que a administração de flúor possa causar distúrbios na via de síntese-secreção celular que possam participar da formação do esmalte fluorótico.

As alterações morfológicas em ameloblastos tratados com $\mathrm{NaF}$ na água de beber foram descritas por MATSUO; KIYOMIYA; KUREBE ${ }^{111}$, 1998, em ratos de oito semanas de vida pós-natal que receberam injeções subcutâneas de $20 \mathrm{mg} / \mathrm{kg}$ de solução de $\mathrm{NaF}$ a $1,25 \%$ duas vezes ao dia durante quatro dias ou $12,62 \mathrm{mM}$ de $\mathrm{NaF}$ na água de beber durante quatro semanas. Neste estudo, os autores observaram alterações celulares semelhantes em ambos grupos experimentais. Foi observado que o aparelho de Golgi dos ameloblastos em secreção apresenta-se localizado na região apical da célula, sendo as pilhas de sáculos unidas umas às outras em seu longo eixo celular. As vesículas de transporte estão localizadas na face cis da pilha e os grânulos de secreção na face trans. Grandes grânulos estavam anormalmente formados e acumulados na região apical do citoplasma, sendo encontrados freqüentemente interligados ao longo eixo da célula. Pequenas vesículas também se acumulavam no citoplasma, especialmente próximas ao complexo de Golgi e grandes grânulos, e também entre sáculos do retículo endoplasmático rugoso. O flúor também induzia alterações morfológicas no complexo de Golgi. Em algumas regiões, 
grupos de pequenas vesículas eram substituídos por sáculos. Alguns destes apresentavam-se também dilatados.

No trabalho de RIBEIRO ${ }^{139}$, 2001, foram utilizadas ratas Wistar de 30 dias de vida pós-natal com peso aproximado de $100 \mathrm{~g}$, as quais receberam 0, 7 e 100ppm de flúor na água de beber durante seis semanas. Neste estudo, foram verificadas algumas alterações ultraestruturais em ameloblastos na fase de maturação da amelogênese. A dosagem tóxica de flúor provocou redução da quantidade de cisternas de REG, dilatação e redução da quantidade de mitocôndrias, dilatação dos lisossomos e redução do tamanho particular de cada vacúolo digestivo.

Alterações semelhantes também foram observadas em ameloblastos secretores por RIBEIRO; ASSIS; HIROTA ${ }^{140}$, 2001, estudando incisivos de ratos adultos que receberam 100ppm de flúor na água de beber ad libitum. Nesta pesquisa, foram observadas na análise morfológica subjetiva áreas de distensão de retículo endoplasmático rugoso no grupo experimental, embora as análises morfométricas para volume e superfície não tenham demonstrado diferença estatisticamente significativa $(p>0,05)$. As mitocôndrias apresentaram um aumento de $29 \%(p<0,01)$ na densidade de volume e volume absoluto e não apresentaram diferença estatística na análise de densidade de superfície.

\subsubsection{Alterações na modulação de ameloblastos causadas pelo flúor}

Um possível efeito do flúor na amelogênese pode estar ligado a um distúrbio na modulação ameloblástica (AOBA ${ }^{4}$, 1994; DENBESTEN ${ }^{42}$, 1999; DENBESTEN; CRENSHAW ${ }^{45}$, 1987; DENBESTEN; THARIANI ${ }^{47}$, 1992; DENBESTEN; CRENSHAW; WILSON ${ }^{48}$, 1985; LIMEBACK ${ }^{105}$, 1994; ROBINSON; KIRKHAM ${ }^{142}$, 1990; SMITH; NANCI; DENBESTEN ${ }^{164}$, 1993; THARIANI; MCKEE; DENBESTEN $^{173}$, 1991).

FEJERSKOV et al. ${ }^{63}$, 1980, observaram uma redução de 4-5 para 2-3 modulações de ameloblastos de incisivos de ratos que receberam 56,5 e 113ppm de flúor na água de beber do $30^{\circ}$ ao $90^{\circ}$ dia de vida pós-natal.

Estes resultados foram semelhantes aos observados por DENBESTEN; CRENSHAW; WILSON ${ }^{48}$, 1985. Estes pesquisadores utilizaram ratos que 
receberam 0, 75, 100 e 150ppm de flúor na água de beber durante cinco semanas. Após este período, os animais receberam calceína e após 30 minutos os incisivos foram removidos e fotografados em luz ultravioleta. A calceína é um marcador para o cálcio que parece estar relacionado com a modulação celular do ameloblasto. Nos animais que receberam flúor, foram observadas alterações nos padrões cíclicos da fase de maturação do esmalte, representados por uma menor marcação pela calceína. Esta relação era dose-dependente, quanto maior a dosagem de flúor, menor a marcação pela calceína (o que significaria menos ciclos de modulação celular). Assim, o menor conteúdo mineral no esmalte fluorótico poderia ser efeito de uma menor quantidade de ciclos de modulação do ameloblasto; a qual por sua vez levaria a uma menor remoção protéica, inibindo a mineralização ou crescimento do cristal. Um fato interessante observado é que no início da fase de maturação do esmalte, a ingestão crônica de $75 \mathrm{ppm}$ de flúor é suficiente para quebrar a modulação dos ameloblastos. A redução no número de modulações juntamente ao consumo crônico excessivo de flúor poderia contribuir para a retenção das proteínas. Em um grupo de animais que receberam 100ppm de flúor durante 15 dias e posteriormente receberam água deionizada. Os animais eram sacrificados em intervalos de três dias quando era utilizada a marcação com o $\mathrm{Ca}^{45}$ imediatamente após a injeção da calceína. Este experimento demonstrou que incorporação de cálcio retornava a valores semelhantes ao grupo controle e que, portanto, os efeitos do flúor são reversíveis.

A redução no número de modulações também foi observada por SMITH; NANCI; DENBESTEN ${ }^{164}$, 1993, utilizando incisivos de ratas Sprague-Dawley que receberam 100ppm de flúor na água de beber. Em algumas áreas foi observado que os ameloblastos permaneciam com a borda rugosa por um período $30 \%$ maior que o normal por ciclo. Houve também uma redução no número de bandas de ameloblastos de borda lisa de 6,4 (grupo controle) para 4,5 (grupo de $100 \mathrm{ppm}$ ). A redução no número de ameloblastos de borda lisa poderia levar a uma menor reabsorção das proteínas da matriz com conseqüente redução na deposição de minerais, durante a fase de maturação 
Entretanto, outros estudos sugerem um aumento no número de modulações de ameloblastos. Segundo THARIANI; McKEE; DENBESTEN ${ }^{173}$, 1991, o flúor numa concentração de 100ppm na água de beber causa em incisivos de ratos não apenas uma redução na área de ameloblastos com borda lisa, como também aumenta o número de ciclos de modulações dos ameloblastos durante a fase de maturação.

A influência do flúor sobre a modulação do ameloblastos também foi estudada por marcação da actina $F$ por fluorescência. NISHIKAWA; JOSEPHSEN ${ }^{124}$, 1987, estudaram os efeitos causados por 113ppm de flúor administrado na água de beber juntamente com 25-30ppm de flúor na dieta durante dois meses em ratos Wistar machos inicialmente com um mês de idade. Utilizando método para localização da actina $F$ foi verificado que nos animais do grupo controle (que não receberam flúor) as bandas de ameloblastos de borda lisa exibiam intensa fluorescência apenas na porção basal. Bandas de ameloblastos de borda rugosa exibiam forte fluorescência na região apical assim como na região basal. A fluorescência da região apical diminui em direção incisal do dente e desapareceu na área adjacente à banda de ameloblastos de borda lisa. O padrão de fluorescência de ambos tipos de ameloblastos repetiam ciclicamente na região de modulação. Nos animais que receberam flúor, o número de áreas marcadas por fluorescência e de regiões de modulação foram reduzidas igualmente indicando que a localização da actina $F$ está relacionada com a modulação do ameloblasto. 
48

Proposição 


\section{Proposição}

Foram utilizados ratos com 0, 7 e 14 dias cujas mães foram submetidas a doses de 0, 7 e 100ppm de fluoreto de sódio na água de beber no período a partir de uma semana antes e durante a gestação e amamentação até o momento da eutanásia. Os incisivos inferiores destes animais foram utilizados para os seguintes estudos:

- Observação morfológica em microscopia óptica;

- Descrição morfológica subjetiva em microscopia eletrônica de transmissão;

- Análise imuno-histoquímica em microscopia óptica utilizando anticorpos primários contra amelogenina;

- Análise do comprimento da matriz do esmalte retido na fase de secreção e após a fase de secreção (fases de transição e maturação);

- Análise morfométrica de altura celular, volume nuclear e citoplasmático de ameloblastos nas fases de secreção e maturação em microscopia óptica. 
50

Proposição 
52

Material e Métodos 


\section{Material e métodos}

\subsection{Tratamento e obtenção dos animais}

Todos os animais foram obtidos do Biotério Central da Faculdade de Odontologia de Bauru (FOB-USP), após parecer favorável do comitê de ética em animais da FOB-USP quanto à condição experimental, manuseio e eutanásia dos ratos.

Inicialmente foram utilizados 27 ratos (Rattus norvergicus, Wistar) adultos do gênero feminino de 90 dias de vida mantidos em três grupos de nove animais em caixas individuais de poliestireno durante 0 período experimental, que receberam como dieta sólida ração granulada da marca Purina para ratos. Na água de beber receberam o seguinte tratamento:

- Grupo experimental I: As ratas receberam água deionizada ad libitum a partir de uma semana antes do acasalamento, sendo um grupo controle para comparação dos resultados dos demais grupos;

- Grupo experimental II: As ratas receberam 7ppm de flúor, ou seja 15,47mg/L de fluoreto de sódio em água deionizada ad libitum (considerada uma dosagem compatível com a recomendada para humanos) a partir de uma semana antes do acasalamento;

- Grupo experimental III: As ratas receberam 100ppm de flúor ou seja, $221 \mathrm{mg} / \mathrm{L}$ de fluoreto de sódio em água deionizada ad libitum (considerada uma dosagem tóxica) a partir de uma semana antes do acasalamento.

Cada grupo experimental foi subdividido em subgrupos cujos filhotes foram sacrificados com 0, 7 e 14 dias de vida pós-natal. Desta forma, as 
fêmeas receberam flúor nas quantidades descritas durante o período entre a semana anterior ao acasalamento e durante toda a gestação e amamentação até o momento da eutanásia dos filhotes.

De cada mãe foram selecionados aleatoriamente quatro filhotes, dois receberam os procedimentos necessários para a análise morfológica ultraestrutural e os outros dois receberam os procedimentos para a análise imuno-histoquímica. Cada grupo experimental (cujas mães receberam 0, 7 e 100ppm de flúor) foi subdividido em três subgrupos etários (0, 7 e 14 dias). Como foram utilizadas três mães, no final obtiveram-se 12 filhotes por subgrupo de estudo, utilizados para o estudo em microscopia óptica (MO) e microscopia eletrônica de transmissão (MET) (FIGURA 1). Para as análises em microscopia eletrônica e óptica foram utilizados apenas cinco animais, sendo o sexto animal utilizado como reserva para substituição ou para controle negativo na análise imuno-histoquímica. 


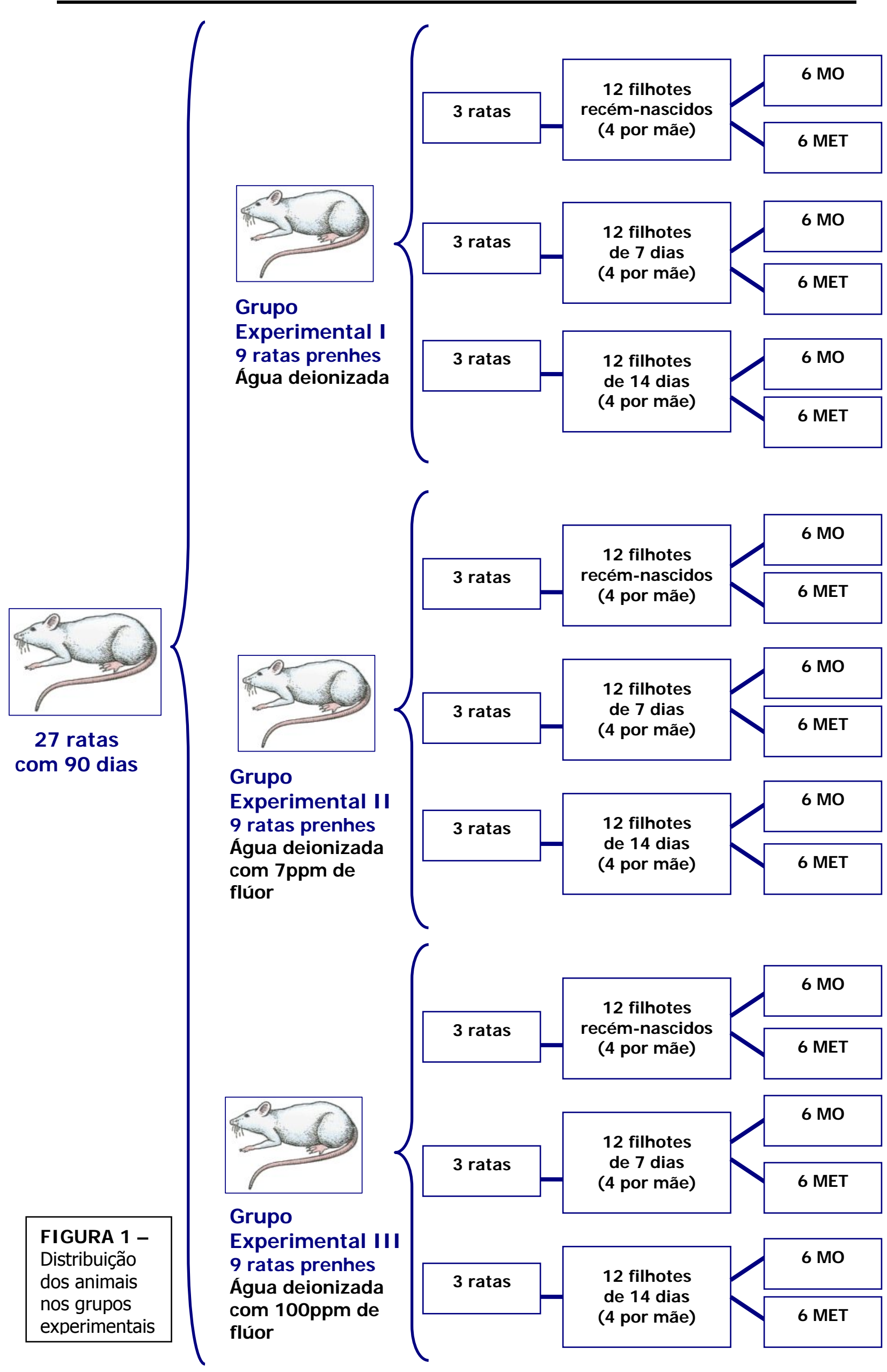


4.2 Eutanásia dos animais, coleta e fixação das hemimandíbulas

Os filhotes tiveram a cabeça decepada e as mandíbulas foram dissecadas e separadas em duas hemimandíbulas.

\subsubsection{Fixação para o estudo em microscopia óptica e análise imuno- histoquímica da amelogenina}

As hemimandíbulas destinadas ao estudo em microscopia óptica e imuno-histoquímico para marcação da amelogenina foram imersas na solução fixadora de paraformaldeido a $4 \%$ + aldeído glutárico a 1\% em tampão cacodilato de sódio $0,08 \mathrm{M}, \mathrm{pH} 7,3$, durante $24 \mathrm{~h}$. O protocolo do preparo da solução fixadora de paraformaldeído encontra-se no ANEXO 1.

\subsubsection{Fixação para o estudo em microscopia eletrônica}

As hemimandíbulas destinadas ao estudo em microscopia eletrônica foram imersas na solução fixadora de aldeído glutárico a 2,5\% em tampão cacodilato de sódio 0,08M, pH 7,3 (NANCI; SLAVKIN; SMITH ${ }^{119}$, 1987; WARSHAWSKY; MOORE ${ }^{179}$, 1967) por 24 horas em geladeira.

\subsubsection{Desmineralização}

As peças foram imersas, em seguida, em solução de ácido etilenodiaminotetra acétido sal dissódico p. a. (EDTA) $\left(\mathrm{C}_{10} \mathrm{H}_{14} \mathrm{~N}_{2} \mathrm{O}_{8} \mathrm{Na}_{2} \cdot 2 \mathrm{H}_{2} \mathrm{O}\right)$ a 4,13\% (WARSHAWSKY; MOORE ${ }^{179}$, 1967) até a completa desmineralização em geladeira. O protocolo para o preparo da solução de EDTA encontra-se no ANEXO 2. 
4.3 Procedimento laboratorial e metodologia para microscopia óptica

Após a desmineralização as hemimandíbulas foram processadas para inclusão em Histosec (Merck) e foram obtidos cortes histológicos de $5 \mu \mathrm{m}$ de espessura que continham o incisivo inferior cortado em seu longo eixo. Estes cortes foram utilizados para análise morfológica e estudo imuno-histoquímico. Os cortes utilizados para o estudo imuno-histoquímico foram montados em lâminas silanizadas.

\subsubsection{Análise morfológica pela coloração de Hematoxilina e Eosina}

As lâminas da mandíbula de cada rato foram coradas pela técnica de Hematoxilina e Eosina (H.E.), para acompanhar a relação do desenvolvimento do dente com os tecidos circunvizinhos. O protocolo para a preparação dos corantes utilizados e o processo de coloração pela técnica da Hematoxilina e Eosina encontram-se, respectivamente, nos ANEXOS 3 e 4.

\subsubsection{Tratamento imuno-histoquímico para amelogenina}

Os anticorpos policlonais primários, dirigidos contra a forma recombinante amelogenina de porco, foram gentilmente cedidos pelo $\mathrm{Dr}$. James P. Simmer, do Departamento de Odontologia Pediátrica, Escola de Odontologia, do Centro de Ciência e Saúde da Universidade do Texas em San Antonio, Texas, USA. As amelogeninas recombinantes foram preparadas a partir de Escherichia coli transgênicas (SIMMER et al. ${ }^{157}, 1994$ ).

Os dois frascos recebidos continham o soro obtido do segundo sangramento de coelho e o mesmo absorvido com extrato de Escherichia coli, com a finalidade de evitar reações cruzadas com proteínas da própria Escherichia coli. A proteína utilizada como antígeno diferencia-se de sua isoforma in vivo (com 173 aminoácidos) por perder uma metionina no término 
N, contendo apenas 172 resíduos aminoácidos (comunicação pessoal do Prof. James P. Simmer durante o desenvolvimento do trabalho de $\operatorname{COSTA}^{33}$, 2000).

Seguindo as instruções do autor, os anticorpos, que foram enviados liofilizados, já foram reconstituídos em $100 \mu \mathrm{L}$ de água destilada e aliquotados em frascos de $10 \mu \mathrm{L}$. No momento da sua utilização, estes frascos foram descongelados e o conteúdo diluído na razão de 1:3000 em PBS.

O processamento imuno-histoquímico seguiu o protocolo apresentado no ANEXO 5, modificado a partir do protocolo apresentado no trabalho de $\operatorname{cosTA}^{33}, 2000$. 


\subsection{Procedimento laboratorial e metodologia para a microscopia eletrônica de transmissão}

Após a completa desmineralização, a parte da hemimandíbula contendo o órgão do esmalte com camada de esmalte subjacente e o tecido conjuntivo labial foi seccionada em faixas com fragmentos de $1 \mathrm{~mm}$ ao longo de cada incisivo, usando o primeiro molar como linha de referência para alinhar as faixas dos estádios da amelogênese ao longo do comprimento do dente (SMITH; NANCI ${ }^{161}$, 1989; SMITH; NANCI ${ }^{163}$, 1996; NANCI; SLAVKIN; SMITH ${ }^{119}$, 1987).

Os fragmentos do incisivo, contendo regiões com ameloblastos nas fases de secreção e maturação, receberam tratamento padronizado como o descrito no ANEXO 6 e foram incluídos em resina Spurr.

Os blocos de cada animal foram trimados, sendo selecionados pelo menos dois por região (secreção e maturação) por animal para o estudo em microscopia eletrônica. Cortes semifinos de $0,5 \mu \mathrm{m}$ foram coletados em lâminas histológicas e corados por solução aquosa de Azul de Metileno 1\% e Azur II $1 \%$, cujo protocolo para preparação encontra-se no ANEXO 7. Esses cortes foram utilizados para observação em microscopio óptico e triagem para a seleção dos cortes para microscopia eletrônica, bem como para análise morfométrica em microscopia óptica.

Os cortes ultrafinos de aproximadamente 70 a $100 \mathrm{~nm}$ foram colhidos sobre telas de cobre de 150 "meshes" recobertas por película de parlódio e foram contrastadas em solução aquosa saturada de acetato de uranila por 20 minutos e em solução de citrato de chumbo por dez minutos.

O exame dos cortes selecionados e a obtenção dos negativos mais representativos para a reprodução das imagens do ameloblasto foram realizados no microscópio eletrônico de transmissão Zeiss EM900 do Núcleo de Apoio à Pesquisa em Microscopia Eletrônica Aplicada à Pesquisa Agropecuária 
(NAP/MEPA) da Escola Superior de Agricultura Luiz de Queiroz, USP, Piracicaba (SP). Os negativos foram obtidos em filmes fotográficos (Kodak Eletron Microscope Film) de 8,3 x 10,2cm em vários aumentos, suficientes para demonstrar as estruturas celulares mais expressivas.

As imagens dos cortes histológicos provenientes dos negativos foram capturadas em Scanner Genius ColorPage-HR7X Slim (em resolução de 300dpi) acoplado em um computador IBM para as observações finais que nortearam a descrição morfológica. 


\subsection{Análises morfométricas e estatísticas}

\subsubsection{Avaliação do comprimento da matriz de esmalte}

Para as medidas de comprimento da matriz do esmalte foram utilizadas as mesmas lâminas utilizadas para análise morfológica no H.E.. Foi avaliado o comprimento da matriz de quatro cortes de cada uma das cinco mandíbulas de cada subgrupo de animais, sendo tomadas as medidas da matriz de esmalte na fase de secreção, após a fase de secreção (englobando a fase de transição e maturação) e o somatório das medidas destas duas fases.

Para a análise morfométrica, o início da fase de secreção foi determinado pela análise visual do início da produção da matriz na região mais próxima à alça cervical. O final da fase de secreção foi considerado quando havia perda da homogeneidade da matriz e a redução da altura dos ameloblastos (SIMMER; $\left.\mathrm{HU}^{156}, 2002\right)$. A partir deste ponto até o desaparecimento da matriz do esmalte na região mais incisal do dente foi considerado como uma região após a secreção, a qual corresponde às fases de transição e de maturação. Vale lembrar também que os ameloblastos de ratos recém-nascidos alcançaram apenas a fase de secreção, não havendo, portanto, resultados para a fase após a secreção nestes animais.

A análise quantitativa microscópica foi realizada em um analisador de imagens KS300 (Kontron Eletronic GMBM) da Carl Zeiss, composto por uma câmera CCD - IRIS RGB - Sony, instalada em um microscópio Zeiss Axioskop 2 trinocular. As imagens obtidas por meio de objetiva de 10x foram transmitidas a um computador IBM.

\subsubsection{Avaliação da altura celular}

Para o cálculo da altura celular, foram utilizados os mesmos cortes semifinos semi-seriados de $0,5 \mu \mathrm{m}$ obtidos em lâminas histológicas e corados com azul de metileno + azur II. No mesmo sistema de análise de imagem, foram obtidas imagens provenientes de cortes escolhidos aleatoriamente por 
subgrupo, ampliadas em objetiva de 100x, onde foram determinadas a altura de 50 ameloblastos na fase de secreção e 50 ameloblastos na fase de maturação de todos subgrupos experimentais.

\subsubsection{Avaliação do volume nuclear absoluto}

Para o cálculo do volume nuclear, foram utilizados os mesmo cortes semifinos semi-seriados de 0,5 $\mu$ m obtidos em lâminas histológicas e corados com azul de metileno + azur II. No mesmo sistema de análise de imagem foram obtidas dez imagens provenientes de cinco cortes escolhidos aleatoriamente por subgrupo, ampliadas em objetiva de $100 x$, onde foram determinados o diâmetro maior (D) e o diâmetro menor (d) de transecções do núcleo da mesma célula orientada no sentido longitudinal em vários cortes. Para o cálculo do volume do núcleo $(\mathrm{Vn})$, foi utilizada a fórmula geométrica do volume do elipsóide, como indicado por PARDINI; TAGA ${ }^{131}$, 1996:

$$
\mathrm{Vn}=\frac{\pi}{6} \cdot \mathrm{D} \cdot \mathrm{d} \cdot \sqrt{\mathrm{D} \cdot \mathrm{d}} \quad\left(\mu \mathrm{m}^{3}\right)
$$

Esse procedimento foi realizado em 50 núcleos de ameloblastos na fase de secreção e 50 núcleos de ameloblastos na fase de maturação em cada um dos subgrupos experimentais, para determinar-se o volume médio por animal. Foram escolhidos os 50 maiores núcleos para se ter certeza que o equador celular estava sendo medido.

\subsubsection{Avaliação da densidade de volume nuclear e citoplasmático}

A fração de volume celular ocupada pelo núcleo (Vvn) e citoplasma (Vvcit) foi determinada pelo princípio básico enunciado por DELESSE ${ }^{40}$, 1847, onde: "a fração de volume (Vvn) ocupada por um objeto num continente, é diretamente proporcional à fração de área (Svn) que o mesmo ocupa num plano seccional ao acaso pelo continente".

Para a obtenção desses parâmetros foram utilizadas as mesmas dez imagens usadas para avaliação do volume nuclear, com aumento nominal de 1000x, capturadas e armazenadas em formato bmp em um computador IBM. 
Para cada imagem obtida, determinou-se no sistema de análise de imagem KS300 da Carl Zeiss a área ocupada pelo citoplasma (Scit) e a área total sobre o ameloblasto (Scel). A densidade de superfície citoplasmática (Svcit) ocupada no ameloblasto é:

$$
\text { Svcit }=\frac{\text { Scit }}{\text { Scel }} \quad\left(\mu \mathrm{m}^{0}\right)
$$

Desta forma, a densidade de volume citoplasmático foi calculada pela mesma fórmula, pois segundo DELESSE ${ }^{40}, 1847$,

$$
\text { Svcit }=\text { Vvcit }\left(\mu \mathrm{m}^{0}\right)
$$

Devido à densidade de superfície nuclear (Svn) ocupada no ameloblasto estar relacionada à densidade de volume citoplasmática, este parâmetro foi calculado pela seguinte fórmula:

$$
\text { Svn }=1-\text { Svcit }\left(\mu \mathrm{m}^{0}\right)
$$

Assim sendo, a densidade de volume nuclear também foi calculada pela mesma fórmula, pois segundo DELESSE ${ }^{40}, 1847$,

$$
\text { Svn }=\operatorname{Vvn}\left(\mu m^{0}\right)
$$

\subsubsection{Avaliação do volume citoplasmático absoluto}

Conhecendo-se o volume nuclear médio $(\mathrm{Vn})$ e a fração de volume celular ocupada pelo núcleo (Vvn) e pelo citoplasma (Vvcit), calculou-se o volume citoplasmático (Vcit) pela relação:

$$
\text { Vcit }=\frac{\text { Vvcit.Vn }}{V_{v n}}\left(\mu \mathrm{m}^{3}\right)
$$

\subsubsection{Análise estatística}

Todos os parâmetros quantitativos foram confrontados pela análise de variância (ANOVA) usando o software MICROSOFT EXCEL, para saber se os mesmos diferiam entre si dentro de um nível de significância de $5 \%(p<0,05)$.

Como indicação da variação das determinações dentro de cada subgrupo, calculou-se a média e o desvio-padrão da média. 
64

Material e Métodos 
66

Resultados 


\section{Resultados}

\subsection{Resultados morfológicos}

5.1.1 Descrição morfológica macroscópica

O aspecto macroscópico revelou os recém-nascidos desdentados, mostrando na hemimandíbula, as regiões mais claras e edemaciadas aonde incisivos e molares iriam se romper.

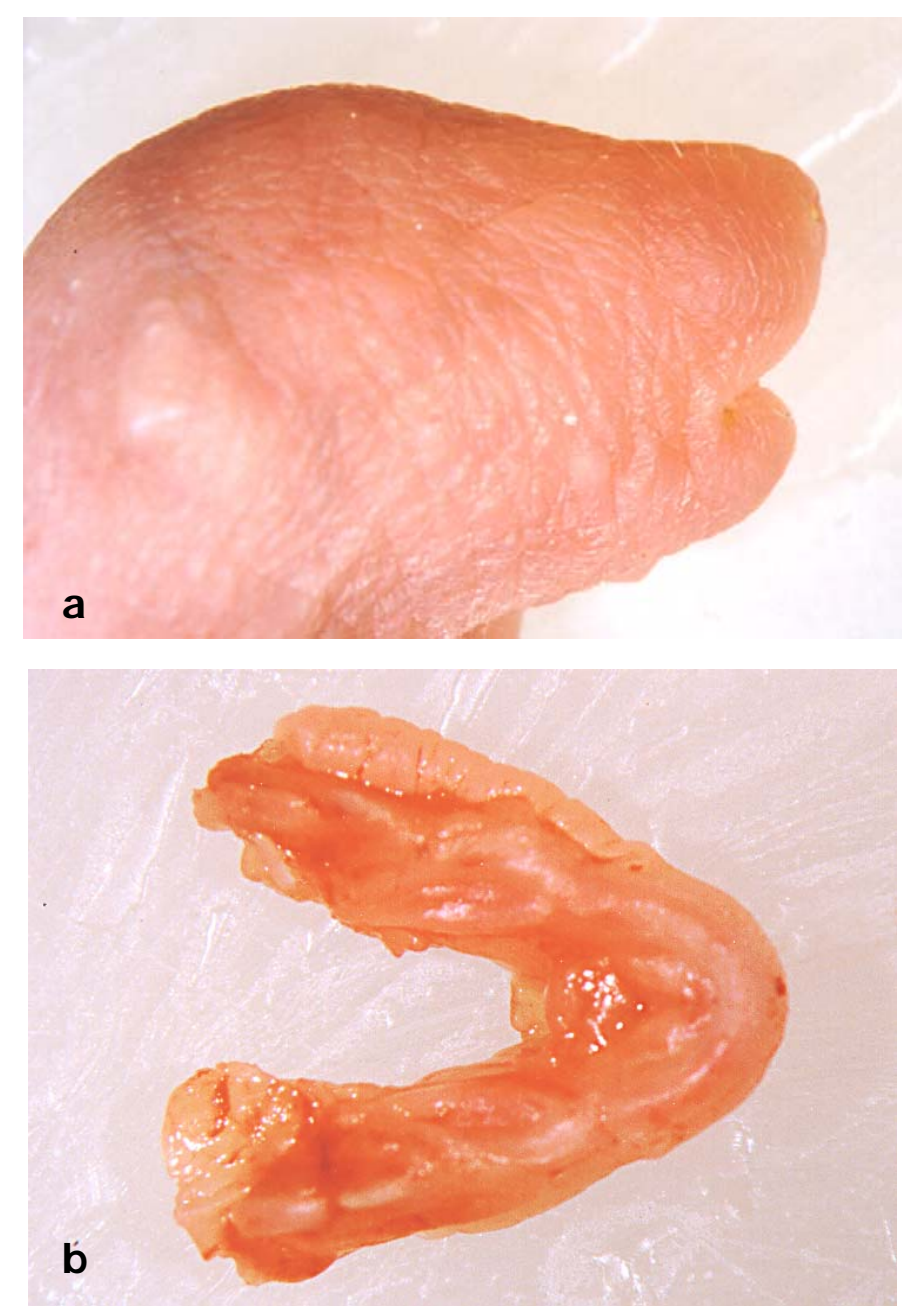

FI GURA 2a-b - Visão macroscópica de rato recém-nascido do subgrupo controle. Observar: a) cabeça de rato; b) detalhe da mandíbula 
68

Resultados

(verso do gloss paper)

$\overline{ }$ 


\subsubsection{Descrição morfológica da microscopia óptica}

\subsubsection{Grupo I : animais recém-nascidos}

A microscopia óptica revelou quadros semelhantes nos animais recémnascidos que receberam 0 (subgrupo controle), 7 ou 100ppm de flúor na água de beber. Os aspectos microscópicos, observados na Hematoxilina e Eosina (H.E.) mostraram fragmentos de hemimandíbula de rato contendo o incisivo e em alguns havia também os três germes dos molares.

Na montagem observada na FIGURA 3 (a-c), nota-se o incisivo inferior ainda em formação, apresentando-se circunscrito por tecido conjuntivo periodontal associado ao osso alveolar, ambos em formação.

Da porção proliferativa (FIGURA 4a) diferenciam-se ameloblastos que iniciam a produção de uma matriz de esmalte homogênea (FIGURA 4b) que aumenta em espessura quanto mais coronal (FIGURA 4c). A porção proliferativa (FIGURA 5a) não mostra o sinal imuno-histoquímico para amelogenina, que pode ser observado na matriz durante a fase de secreção (FIGURA 5b). Nos cortes utilizados como controles negativos neste e nos demais subgrupos, 0 sinal imuno-histoquímico também não foi detectado.

A marcação para amelogenina mostrou-se pontual e intensa no início da secreção do esmalte (FIGURA 6a). Durante todo o restante da secreção, a marcação mostrou-se homogênea, apresentando sempre uma maior intensidade na região da junção amelodentinária (FIGURA 6b). Essa intensidade foi também observada na coloração de H.E. (FIGURA 6c). Na região apical dos ameloblastos, observou-se um sinal moderado puntiforme (FIGURA 6a).

O desenvolvimento da matriz do esmalte e as marcações observadas nos subgrupos de animais recém-nascidos que receberam 7 e 100ppm foram semelhantes as observadas no subgrupo controle (FIGURA 7a-b), mostrando um sinal pontual no início da fase de secreção e um aspecto mais homogêneo à medida que aumentava a quantidade de esmalte produzido. Nesta região secretora mais coronal, a marcação foi mais intensa no esmalte, que na pré- 
dentina. O gel da matriz mostrou marcação intensa e homogênea. Os ameloblastos iniciando a modulação para a fase de maturação foram raramente detectados na maioria dos ratos recém-nascidos. 


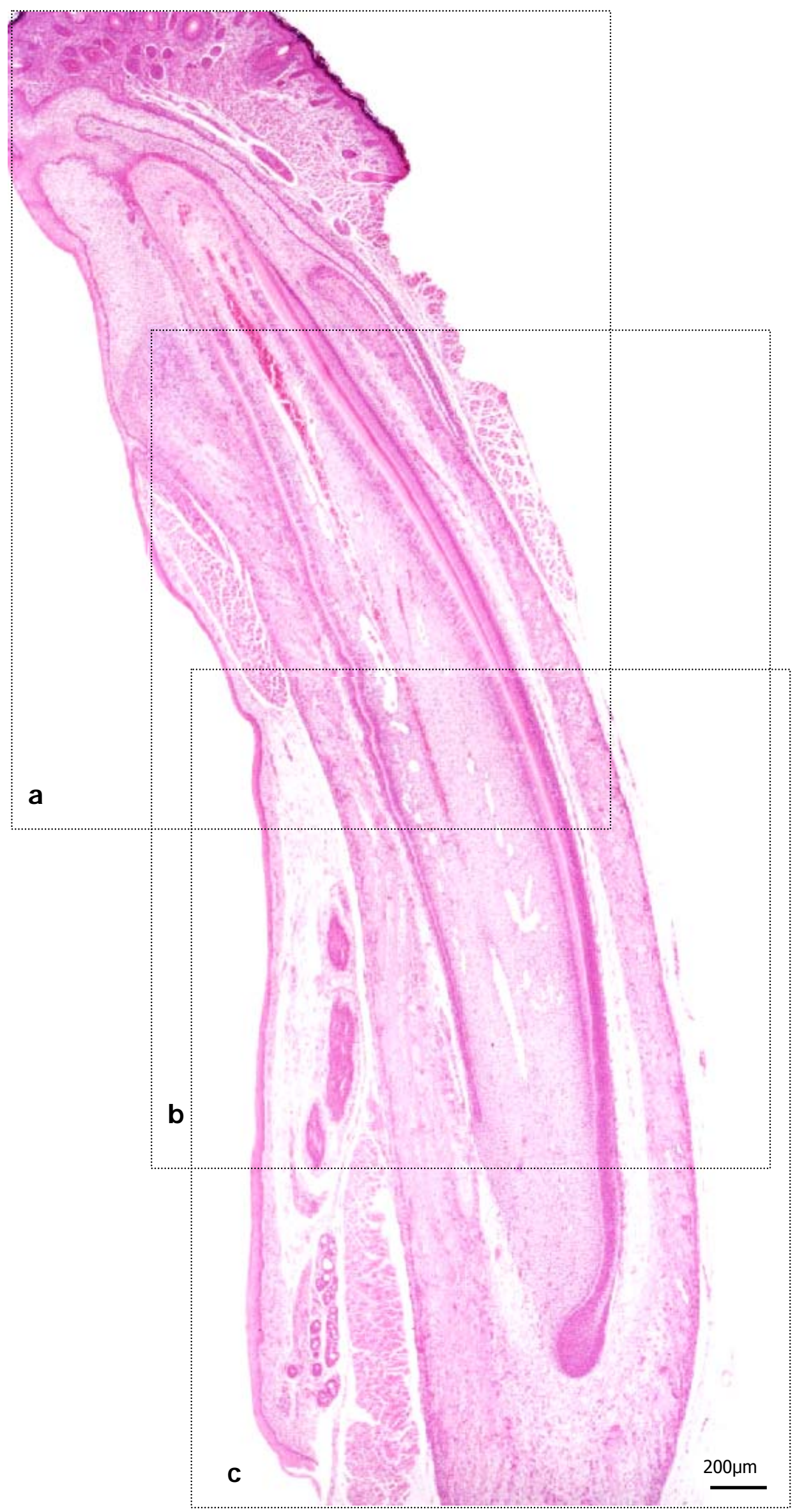

FI GURAS 3a-c - Montagem de cortes histológicos de germe de incisivo de rato recémnascido do subgrupo controle para visão panorâmica. H.E. 
72

Resultados

(verso do gloss paper)

$\overline{\overline{2}}$ 

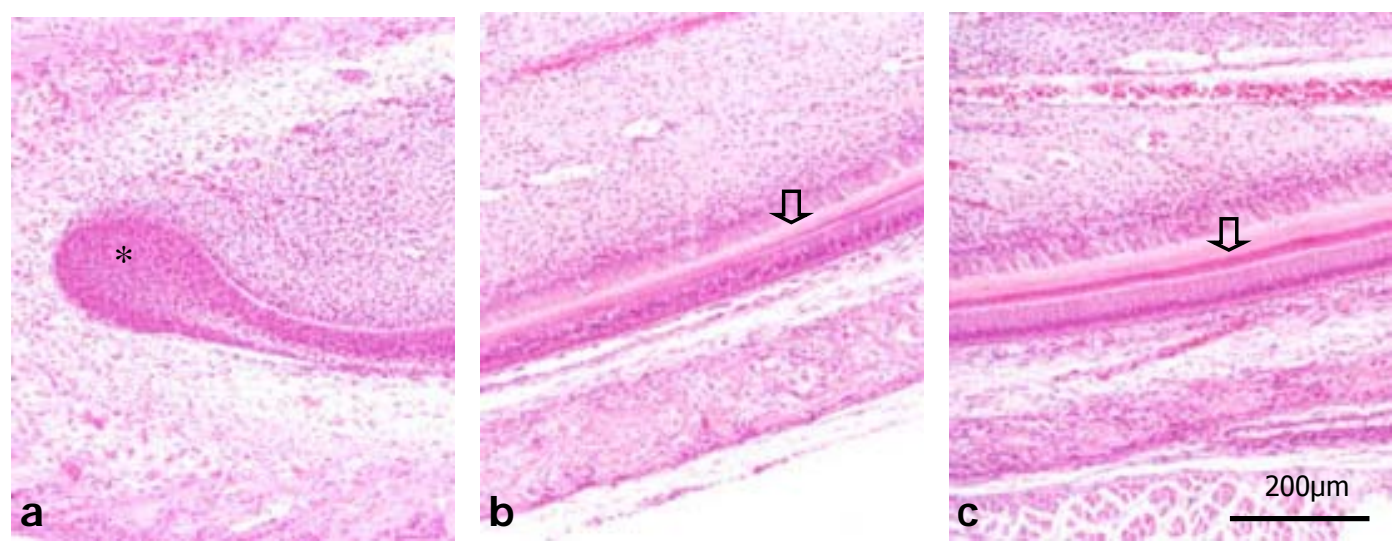

FI GURAS 4a-c - Cortes histológicos de germe de incisivo de rato recém-nascido do subgrupo controle. Observar: a) região apical proliferativa (asterisco); b) início (seta) e c) desenvolvimento da matriz do esmalte (seta). H.E.
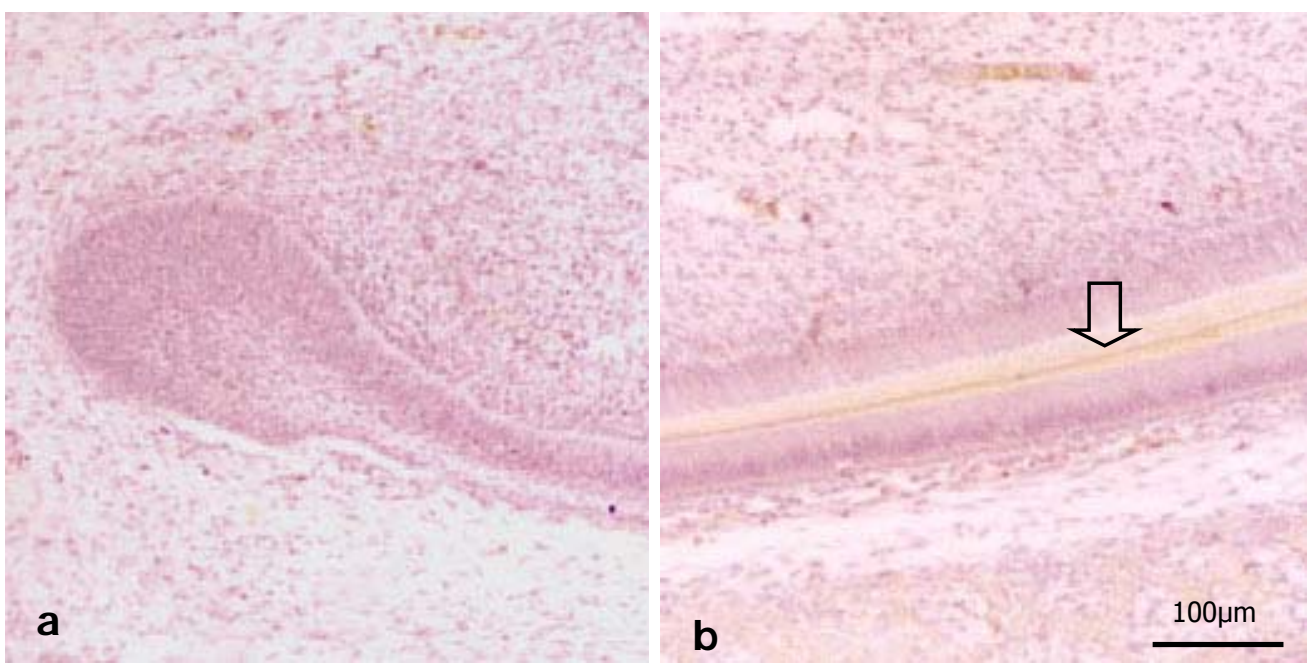

FI GURAS 5a-b - Cortes histológicos de germe de incisivo de rato recém-nascido do subgrupo controle. Observar: a) porção proliferativa e b) matriz de esmalte imunomarcada na porção secretora (seta). Reação imuno-histoquímica para amelogenina 
74

Resultados

(verso do gloss paper)

ב. 

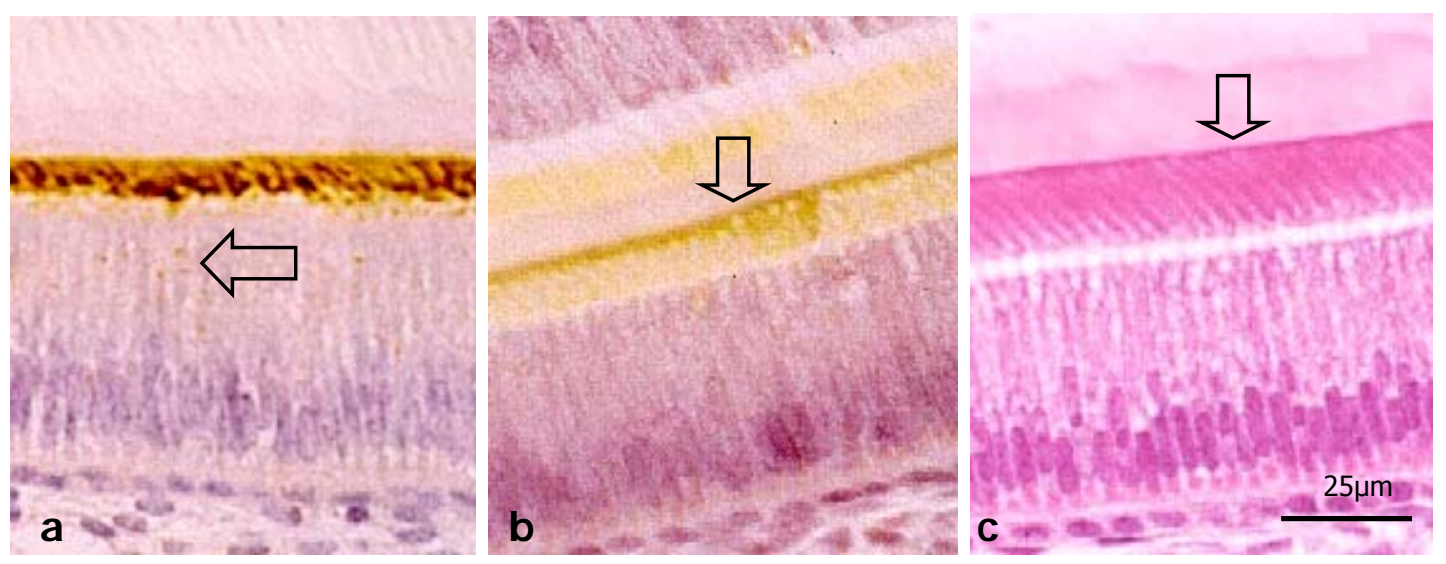

FI GURAS 6a-c - Cortes histológicos de germe de incisivo de rato recém-nascido do subgrupo controle. Observar: a) marcação intensa na matriz e discreta nos ameloblastos (seta); b) forte marcação na junção amelodentinária (seta) e c) coloração mais intensa no H.E (seta). Reação imuno-histoquímica para amelogenina $(7 a, b)$ e H. E. (7c)
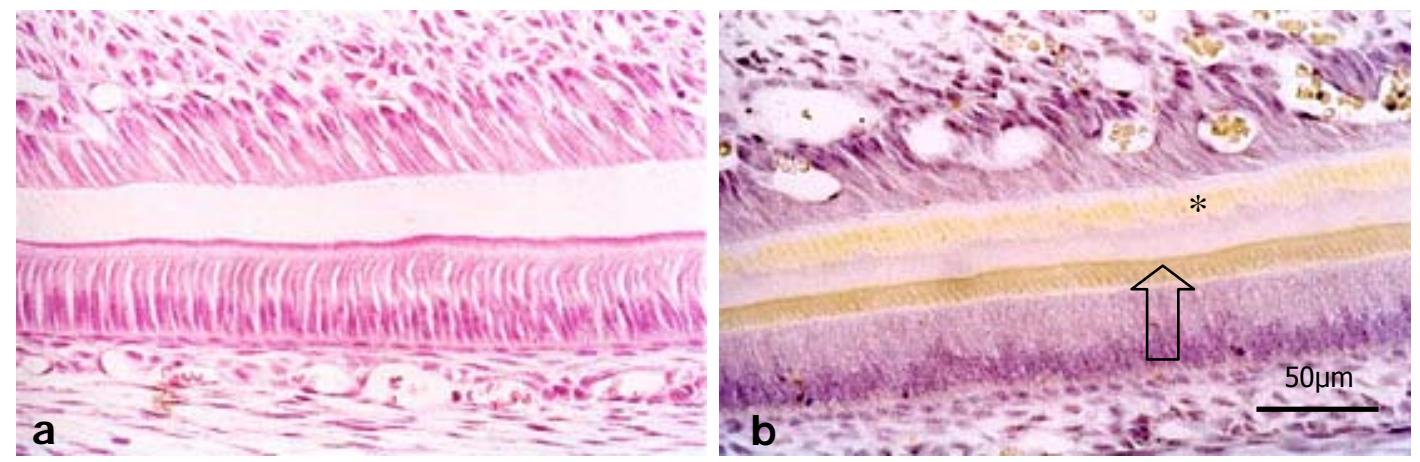

FI GURAS 7a-b - Cortes histológicos de germe de incisivo de rato recém-nascido do subgrupo de 100ppm. Observar: a) início da amelogênese (H.E.); b) a marcação na pré-dentina (asterisco) e na matriz de esmalte (seta). (Reação imuno-histoquímica para amelogenina) 
76

Resultados

(verso do gloss paper)

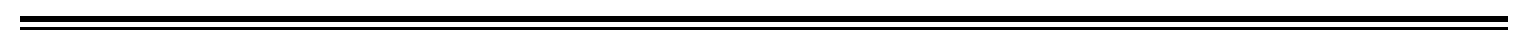




\subsubsection{Grupo II : animais com sete dias de vida pós-natal}

A microscopia óptica revelou quadros semelhantes nos animais recémnascidos que receberam 0 (subgrupo controle), 7 ou 100ppm de flúor na água de beber. Os aspectos microscópicos, observados na Hematoxilina e Eosina (H.E.) mostraram fragmentos de hemimandíbula de rato compostos por três germes de molares e um incisivo, seccionados aproximadamente em plano paralelo ao longo eixo dessas estruturas.

Nas FIGURAS 8a-d, nota-se o incisivo inferior ainda em formação, apresentando-se circunscrito por tecido conjuntivo periodontal associado ao osso alveolar, ambos em formação. Todos os germes mostram ameloblastos secretores e modulados para a fase de maturação, mas o dente ainda não irrompeu na cavidade bucal.

A matriz do esmalte apresentou variações discretas em sua homogeneidade. Na fase de secreção, o gel da matriz mostrou-se bastante homogêneo, sendo que essa característica perdia-se com o avançar da amelogênese. Na morfologia dos ameloblastos, houve alterações compatíveis com as fases de secreção, transição e maturação.

Nas FIGURAS 9a-d, pode ser observado na reação imuno-histoquímica para amelogenina um quadro semelhante ao observado nos animais do subgrupo controle de recém-nascidos. Observa-se nesta seqüência de figuras, a ausência de marcação na região proliferativa (FIGURA 9a), o aumento na marcação no início da fase de secreção com aspecto mais heterogêneo (FIGURA 9b), a marcação mais homogênea no final da fase de secreção (FIGURA 9c) e a redução na marcação na fase de maturação (FIGURA 9d). Deve-se lembrar que a fase de maturação não foi observada em animais recém-nascidos. Nas FIGURAS 9e e 9f, observam-se padrões semelhantes nos animais cujas mães receberam 7 e 100ppm de flúor, respectivamente, mas com padrão de marcação mais intenso que o controle, na matriz de esmalte em maturação. 
A seqüência das FIGURAS 10a-h, mostra os cortes histológicos do subgrupo de ratos de sete dias de idade que receberam $7 \mathrm{ppm}$ de flúor. Observa-se nessa seqüência que a marcação imuno-histoquímica inicia-se de forma intensa e difusa no ameloblasto, com pouca marcação inespecífica em odontoblastos, matriz de dentina e tecido conjuntivo (FIGURA 10a). A seguir esta marcação passa a ser mais intensa na região da junção amelodentinária (FIGURA 10b). No restante do esmalte, a marcação é heterogênea e puntiforme. À medida que o esmalte é depositado, a marcação na região amelodentinária diminui, embora o aspecto heterogêneo permaneça (FIGURA 10c). Com o aumento da secreção do esmalte, permanece ainda intensa a marcação nas regiões da junção amelodentinária e do esmalte recémsintetizado (FIGURA 10d). Com a secreção de toda camada de esmalte, a marcação na região central do esmalte diminui (FIGURA 10e). Quando inicia a fase de maturação do esmalte, a marcação volta a ser intensa (provavelmente devido à degradação de parte das moléculas de amelogenina) havendo novamente o aparecimento de áreas com uma marcação pontilhada, mesmo na região central do esmalte, onde predominava anteriormente a homogeneidade da amostra. Voltam a ser mais intensas as pigmentações nas áreas da junção amelodentinária e na camada mais superficial do esmalte (onde a degradação das proteínas do esmalte deve começar primeiramente). Nesta região observam-se também evidentes espaços negativos mais ou menos hexagonais entre as áreas marcadas pela imuno-histoquímica, que correspondem aos cristais de apatita que aumentam gradativamente até ocuparem, de modo coordenado, quase todo o espaço do material orgânico do esmalte em formação (FIGURA 10f). Com o avanço do processo de maturação, o esmalte mostra-se cada vez mais marcado pela reação imuno-histoquímica, especialmente nas áreas citadas anteriormente (FIGURA 10g). A parte final da matriz do esmalte em maturação, que resta após o processamento imunohistoquímico e é possível de ser observada no corte, está representada por um pequeno filete de matriz orgânica altamente reativo a imuno-histoquímica (FIGURA 10h), como marcação de intensidade semelhante à observada na camada superficial do esmalte (FIGURA 10g). Esta intensidade de marcação 
provavelmente ocorre por que os epítopos das amelogeninas estão mais livres para agregar-se ao anticorpo.

O comportamento da marcação imuno-histoquímica para amelogenina no subgrupo de ratos de sete dias que receberam 100ppm de flúor, pela análise morfológica subjetiva, parecer ser similar àqueles que receberam sete ppm de flúor. 
80

Resultados

(Verso de papel comum)

" 

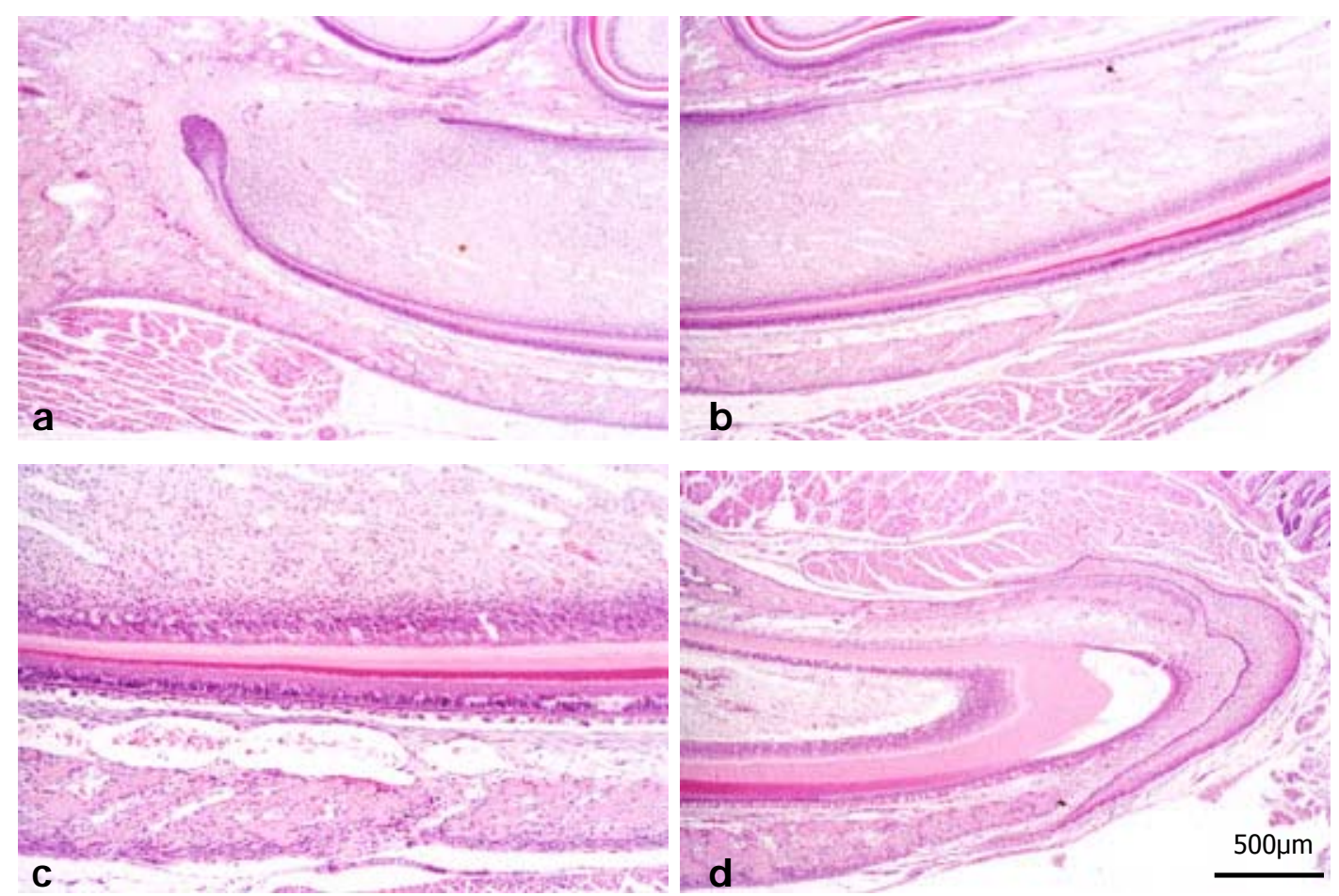

FI GURAS 8a-d - Cortes histológicos de germe de incisivo de rato com sete dias de vida pósnatal do subgrupo controle. Observar: a) região proliferativa; b e c) região secretora do esmalte; d) dente ainda não irrompido na cavidade bucal. H.E. 
82

Resultados

(verso do gloss paper)

$\overline{ }$ 

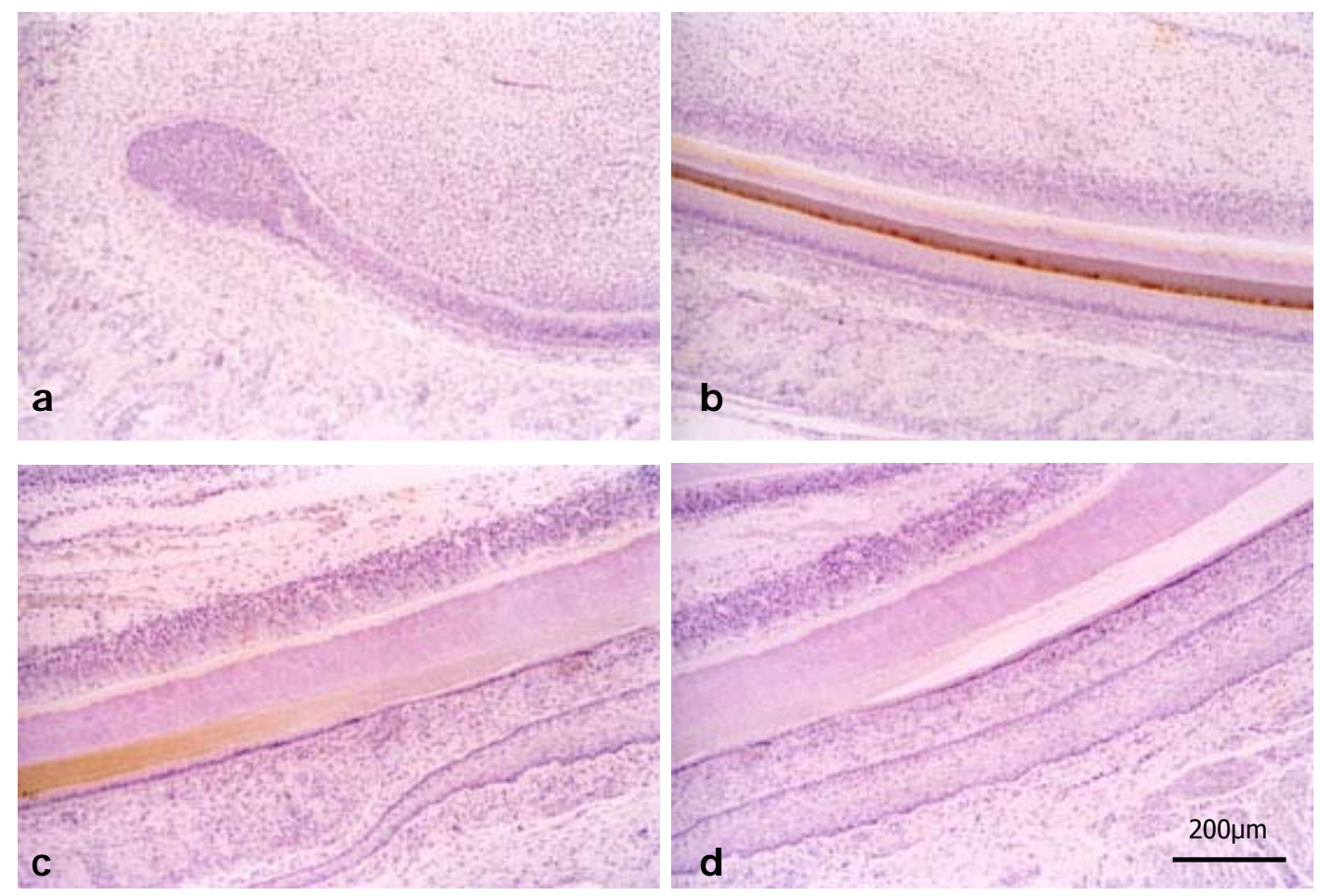

FI GURAS 9 a - d - Cortes histológicos de germe de incisivo de rato com sete dias de vida pós-natal do subgrupo controle. Observar: a) região proliferativa; b) região secretora do esmalte; c) região de transição de secreção para maturação; d) região de maturação. Reação imuno-histoquímica para amelogenina
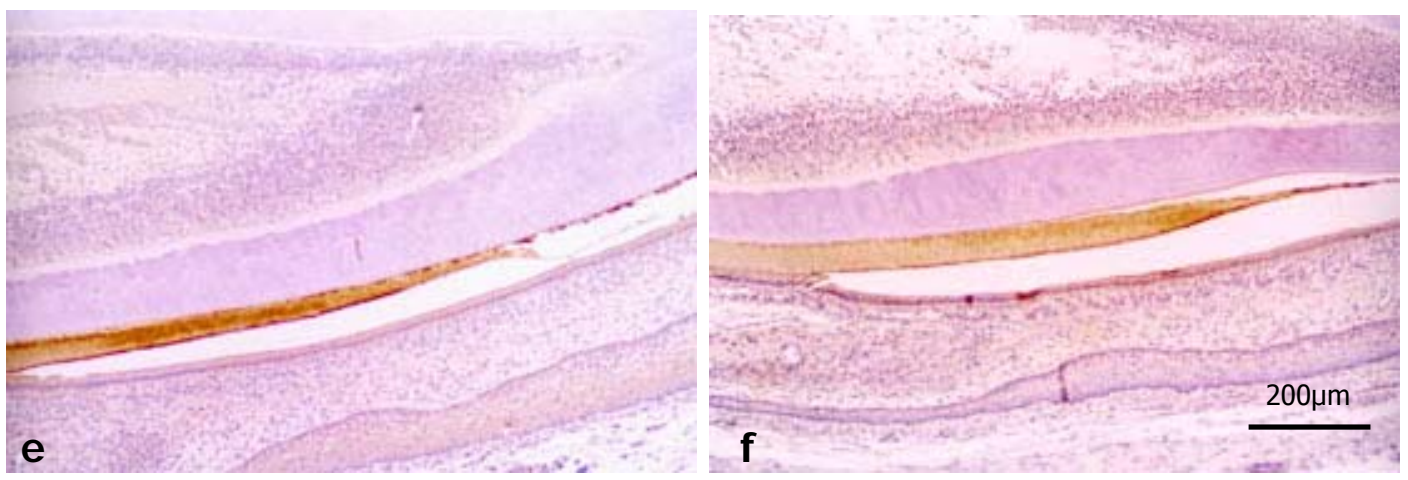

FI GURAS 9 e - f - Cortes histológicos de germe de incisivo de rato com sete dias de vida pósnatal dos subgrupos de 7 e 100ppm. Observar: e) região de maturação no subgrupo de 7ppm; f) região de maturação do subgrupo de 100ppm. Reação imuno-histoquímica para amelogenina 
84

Resultados

(verso do gloss paper)

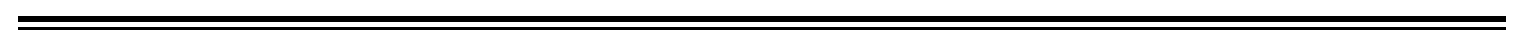



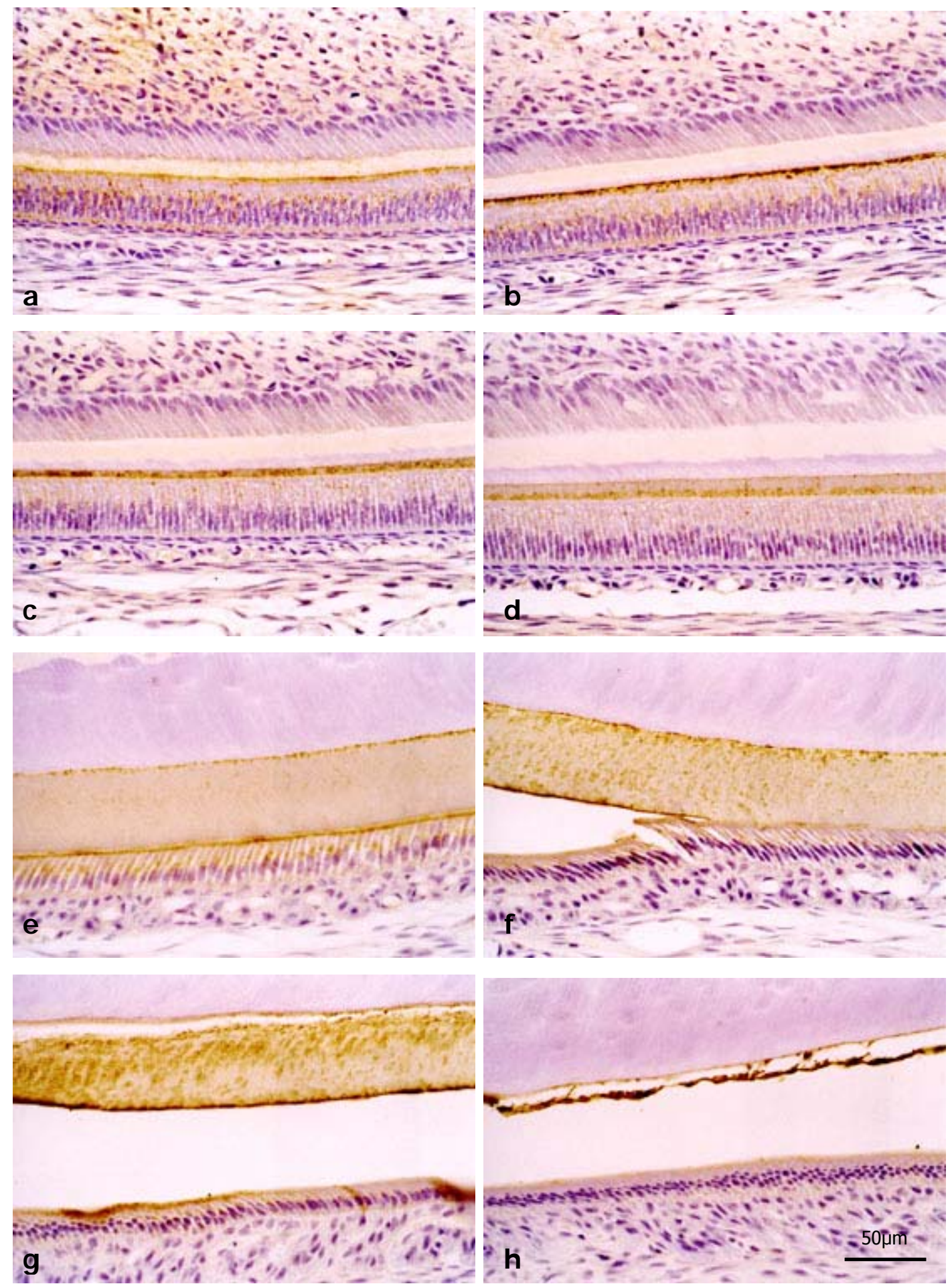

FI GURAS 10a - $\mathbf{h}$ - Cortes histológicos de germe de incisivo de rato com sete dias de vida pós-natal do subgrupo de 7ppm. Observar: a) marcação inespecífica na matriz dentinária e tecido conjuntivo, b e c) marcação intensa na junção amelodentinária, d e e) padrão de marcação mais homogênea, $f$ e g) padrão de marcação heterogênea e puntiforme, $h$ ) marcação da matriz retida. Reação imuno-histoquímica para amelogenina 
86

Resultados

(verso do gloss paper)

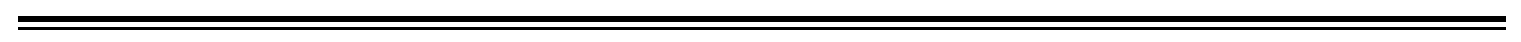




\subsubsection{Grupo I I : animais com 14 dias de vida pós-natal}

Nos animais com 14 dias de vida pós-natal, o incisivo inferior apresentava-se numa etapa mais adiantada de irrupção dentária. Os aspectos microscópicos, observados na Hematoxilina e Eosina (H.E.) mostraram fragmentos de hemimandíbula de rato compostos por três germes de molares e um incisivo, seccionados aproximadamente em plano paralelo ao longo eixo dessas estruturas.

Os resultados morfológicos dos animais de 14 dias de vida pós-natal dos subgrupos de 0, 7 e 100ppm mostraram padrões semelhantes de marcações observados em animais de sete dias, com todo processo evolutivo registrado anteriormente. Portanto, o aspecto morfológico observado nos animais do grupo de 14 dias permanece similar ao constatado em animais do grupo de 7 dias, como pode ser notado nas FIGURAS 11, 12 e 13. 
88

Resultados

(verso de papel comum)

$\overline{ }$ 

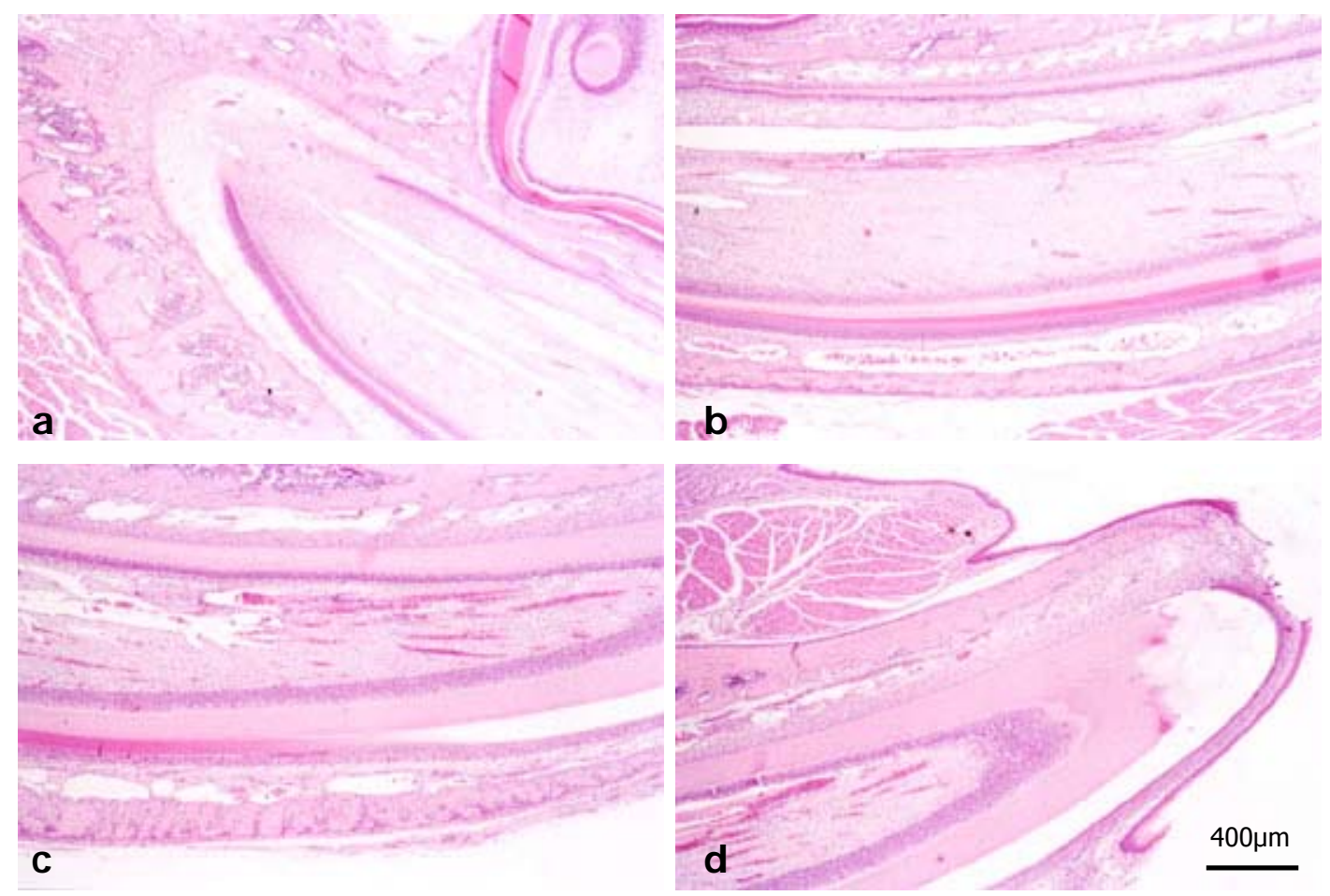

FI GURAS 11a - d - Cortes histológicos de germe de incisivo de rato com 14 dias de vida pósnatal do subgrupo controle a) região proliferativa; b) região de secreção do esmalte; c) região de transição de secreção para maturação; d) região coronal do incisivo. H. E.
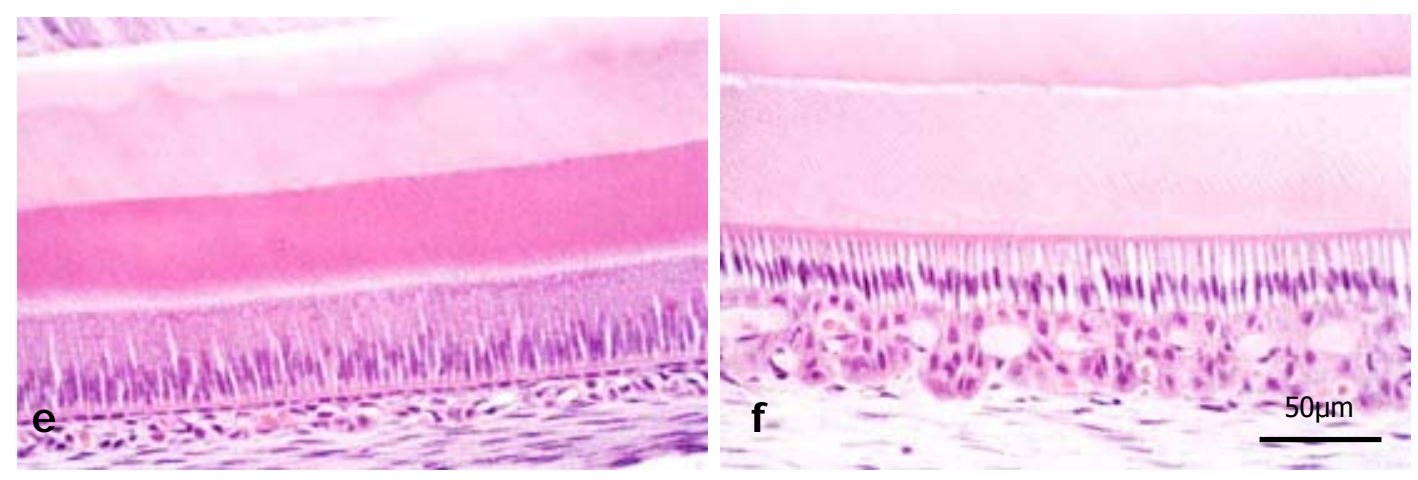

FI GURAS 11e - f - Cortes histológicos de germe de incisivo de rato com 14 dias de vida pósnatal do subgrupo controle e) região de secreção; f) região de maturação H. E. 
90 (verso do gloss paper)

Resultados 

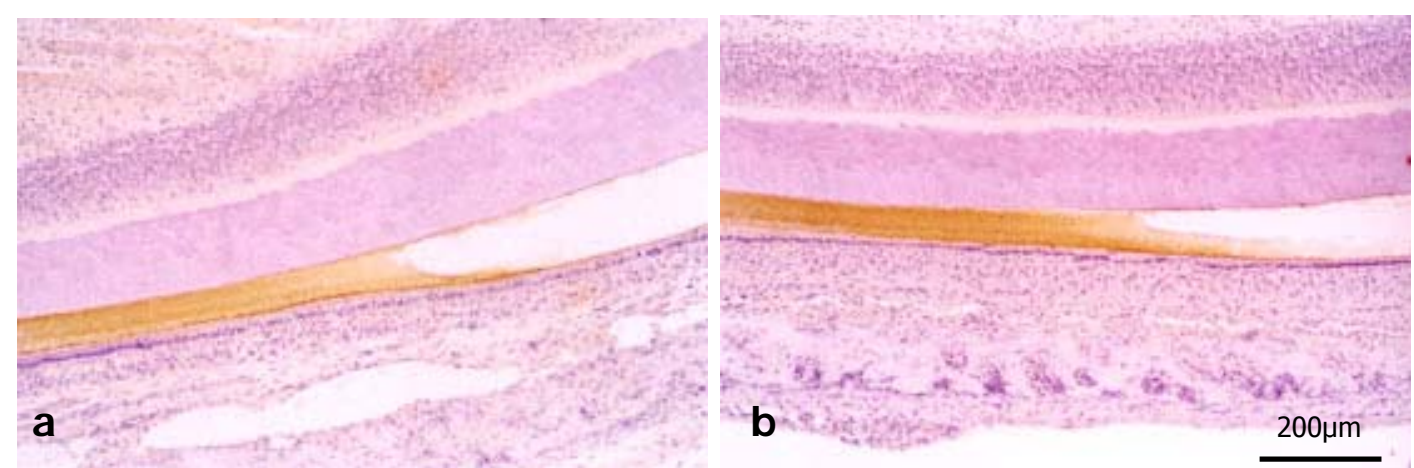

FI GURAS 12a - b - Cortes histológicos de germe de incisivo de rato com 14 dias de vida pósnatal dos subgrupos controle e de 7ppm, respectivamente. Reação imuno-histoquímica para amelogenina

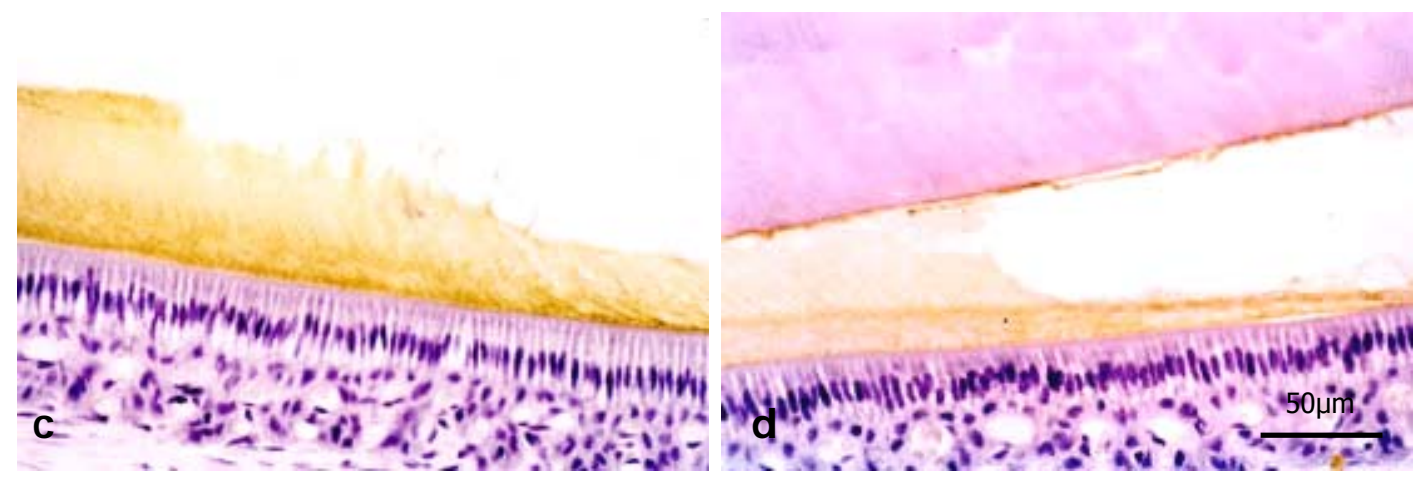

FI GURAS 13 c - d - Cortes histológicos da fase de maturação do germe de incisivo de rato com 14 dias dos subgrupos controle e de 100ppm, respectivamente. Reação imunohistoquímica para amelogenina 
(verso do gloss paper) 


\subsubsection{Descrição morfológica da microscopia eletrônica}

\subsubsection{Grupo I: animais recém-nascidos}

\subsection{Descrição do ameloblasto do grupo controle}

As observações dos cortes ultrafinos em Microscópio Eletrônico de Transmissão (MET) e das imagens digitalizadas e impressas mostraram neste grupo que a região apical antes do início do processo de Tomes é preenchida por cisternas de retículo endoplasmático granular (REG) e alguns pequenos grânulos de secreção distribuídos por todo citoplasma apical (FIGURA 14a, b). A concentração destes grânulos parece ser maior na região do processo de Tomes. A matriz recém-sintetizada parece estar distribuída de forma homogênea em volta do processo (FIGURA 14c). A porção apical do ameloblasto no início do processo de Tomes é marcada por uma região mais eletrondensa formada por uma rede de complexo juncional (FIGURA 14a). A região média mostra o complexo de Golgi formado por vários dictiossomas arranjados em poucos e pequenos sáculos próximos da rede intensa de REG. Estes últimos apresentam suas cisternas homogêneas e paralelamente distribuídas entre si (FIGURA 14d), estando localizadas no sentido longitudinal do ameloblasto ao lado de algumas porções de microfilamentos (FIGURA 14e). O núcleo alongado ocupa grande parte da região suprabasal, mostrando quase toda cromatina desespiralizada (eucromatina) (FIGURA 14f). Uma grande quantidade de pequenas mitocôndrias arredondadas, ovaladas ou alongadas concentra-se entre o núcleo e o plasmalema basal (FIGURA 14f) e uma pequena quantidade está distribuída por todo o restante do citoplasma. Convém lembrar que nesta idade os ameloblastos estão na fase de secreção, não sendo observadas células na fase de maturação. 


\subsection{Descrição do ameloblasto do grupo de 7ppm}

O ameloblasto secretor dos ratos recém-nascidos do grupo de 7ppm mostra na região apical imediatamente antes do processo de Tomes vários vacúolos claros, similares aos encontrados nos animais de 7 ou 14 dias com tratamento de 7ppm de flúor, mas diferentes dos observados nos animais dos grupos de 100ppm. Os pequenos grânulos de secreção, presentes no processo de Tomes entre porções de matriz interprismática, parecem em quantidade e morfologia similares aos observados em ameloblastos do grupo controle. $\mathrm{Na}$ região média e basal, o REG mostra morfologia normal e as mitocôndrias de vários formatos também não indicam alterações morfológicas.

\subsection{Descrição do ameloblasto do grupo de 100 ppm}

Os ameloblastos dos animais recém-nascidos do grupo experimental de 100ppm observados no MET mostraram na região do processo de Tomes presença de enormes vacúolos, lembrando formações císticas (FIGURA 15a, b), algumas vezes com material eletrondenso no seu interior. Embora ocorra essa vacuolização, a maioria das interfaces entre os processos de Tomes e a matriz recém-sintetizada (FIGURA 15a, b, c) mostrou-se com morfologia preservada semelhante ao observado no grupo controle. Mesmo os pequenos grânulos de secreção (FIGURA 15b, c) aparecem sem alterações morfológicas, entretanto parece estar em quantidade reduzida em relação ao controle. Em toda a região supranuclear, o REG apresentou cisternas mais dilatas e desorganizadas (FIGURA 15d, e, f) que as observadas no grupo controle. Alguns dos sáculos do aparelho de Golgi parecem mais dilatados e menos organizados também (FIGURA 15f). Na região basal, as mitocôndrias mostraram-se, em sua maioria, mais dilatadas e com as cristas menos organizadas que as observadas no grupo controle (FIGURA 15g, h). As mitocôndrias de outras regiões também apresentaram essas mesmas características. 

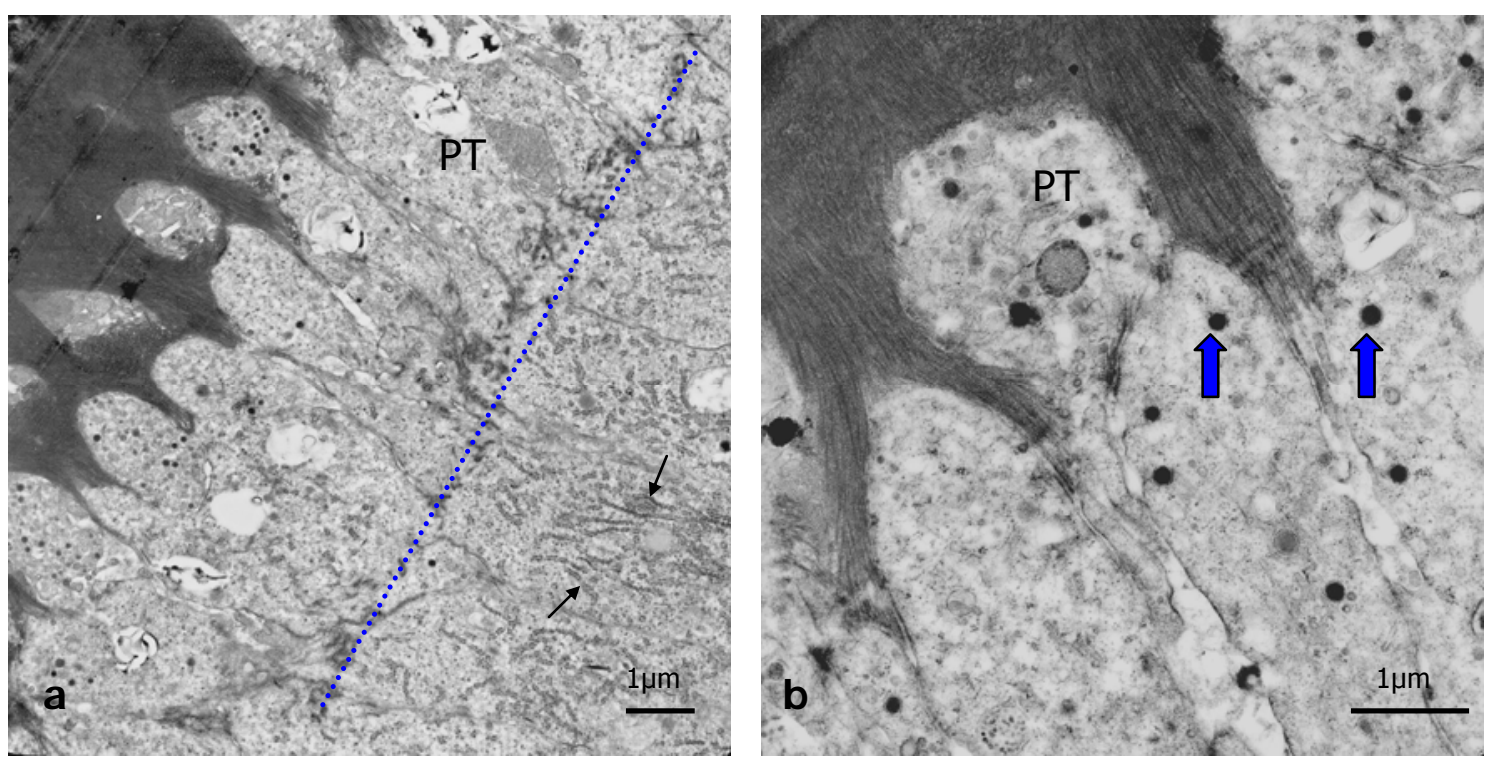

FI GURA 14 (a-b) - Corte ultrafino de ameloblasto secretor de rato recém-nascido do grupo controle. Observar na região apical: a) quando inicia a secreção da matriz de esmalte, o processo de Tomes (PT) é marcado por uma região mais eletrondensa, formada por uma rede de complexo juncional (linha pontilhada) e algumas cisternas de retículo endoplasmático granular (setas) e no processo de Tomes alguns pequenos grânulos de secreção (setas largas); b) Ampliação da FIGURA 14a 
96

Resultados 

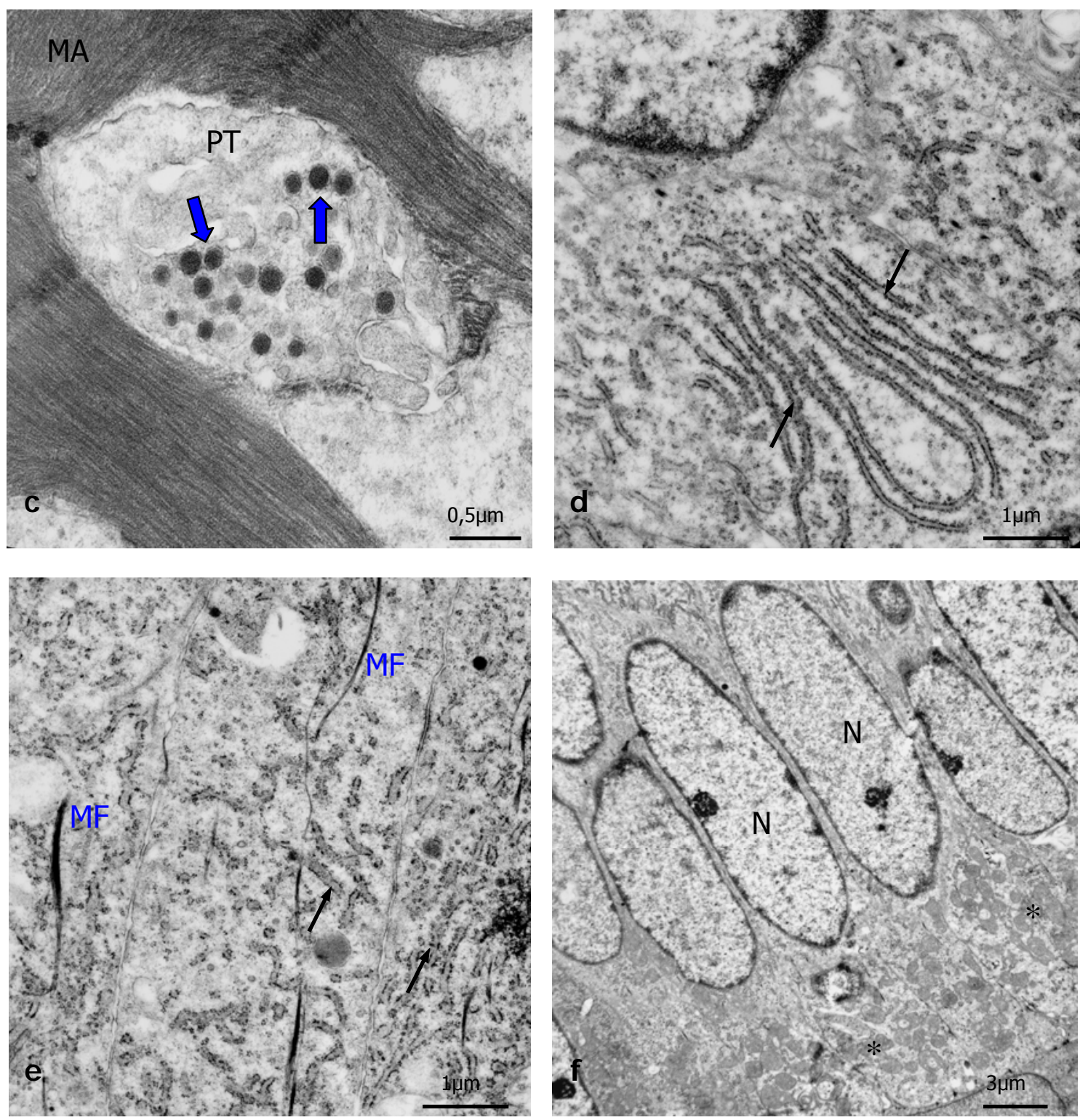

FIGURA 14 (c-f) - Corte ultrafino de ameloblasto secretor de rato recém-nascido do grupo controle. Observar: c) o processo de Tomes (PT) apresenta uma concentração dos grânulos de secreção (setas largas) e a matriz de esmalte (MA) recém-sintetizado parece estar distribuída de forma homogênea em volta do processo; d-e) a região média mostra uma rede intensa de retículo endoplasmático granular (setas) apresentando suas cisternas homogêneas e paralelamente distribuídas entre si, seguindo o sentido longitudinal do ameloblasto ao lado de algumas porções de microfilamentos (MF); e f) o núcleo (N) alongado ocupa grande parte da região suprabasal, mostrando evidente eucromatina e a maior parte das pequenas mitocôndrias concentra-se entre o núcleo e o plasmalema basal $(*)$ 
98

Resultados

(verso do gloss paper)

 

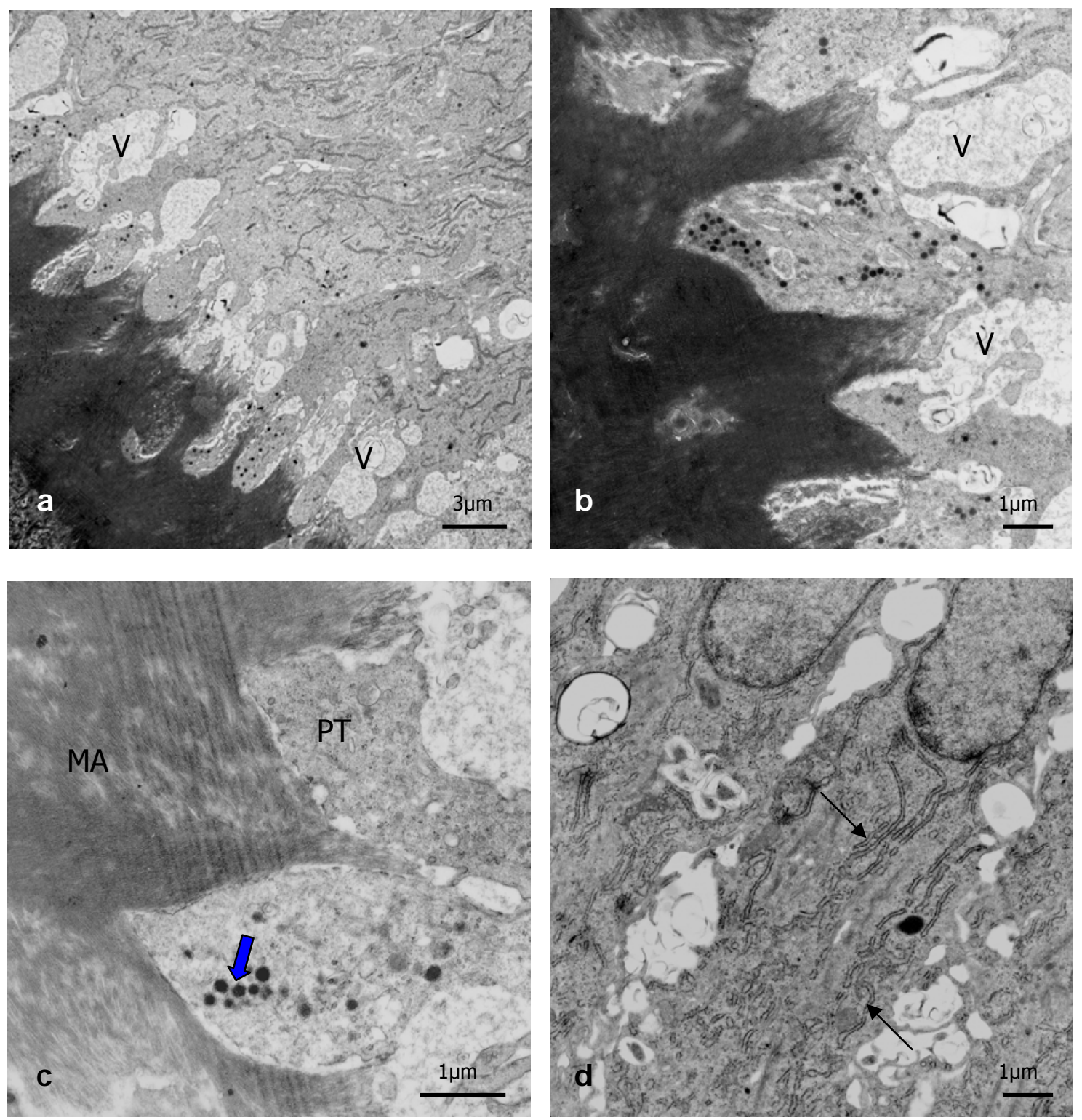

FI GURA 15 (a-d) - Corte ultrafino de ameloblasto secretor de rato recém-nascido do grupo de 100ppm. Observar: a e b) enormes vacúolos (V) localizados na região do processo de Tomes; c) a maioria das interfaces entre os processos de Tomes (PT) e a matriz (MA) recémsintetizada e os grânulos de secreção (seta) aparecem preservados e com morfologia normal; d) na região supranuclear, o retículo endoplasmático rugoso (REG) (setas) parece tortuoso 
100

Resultados

(verso do gloss paper)

$\overline{ }$ 

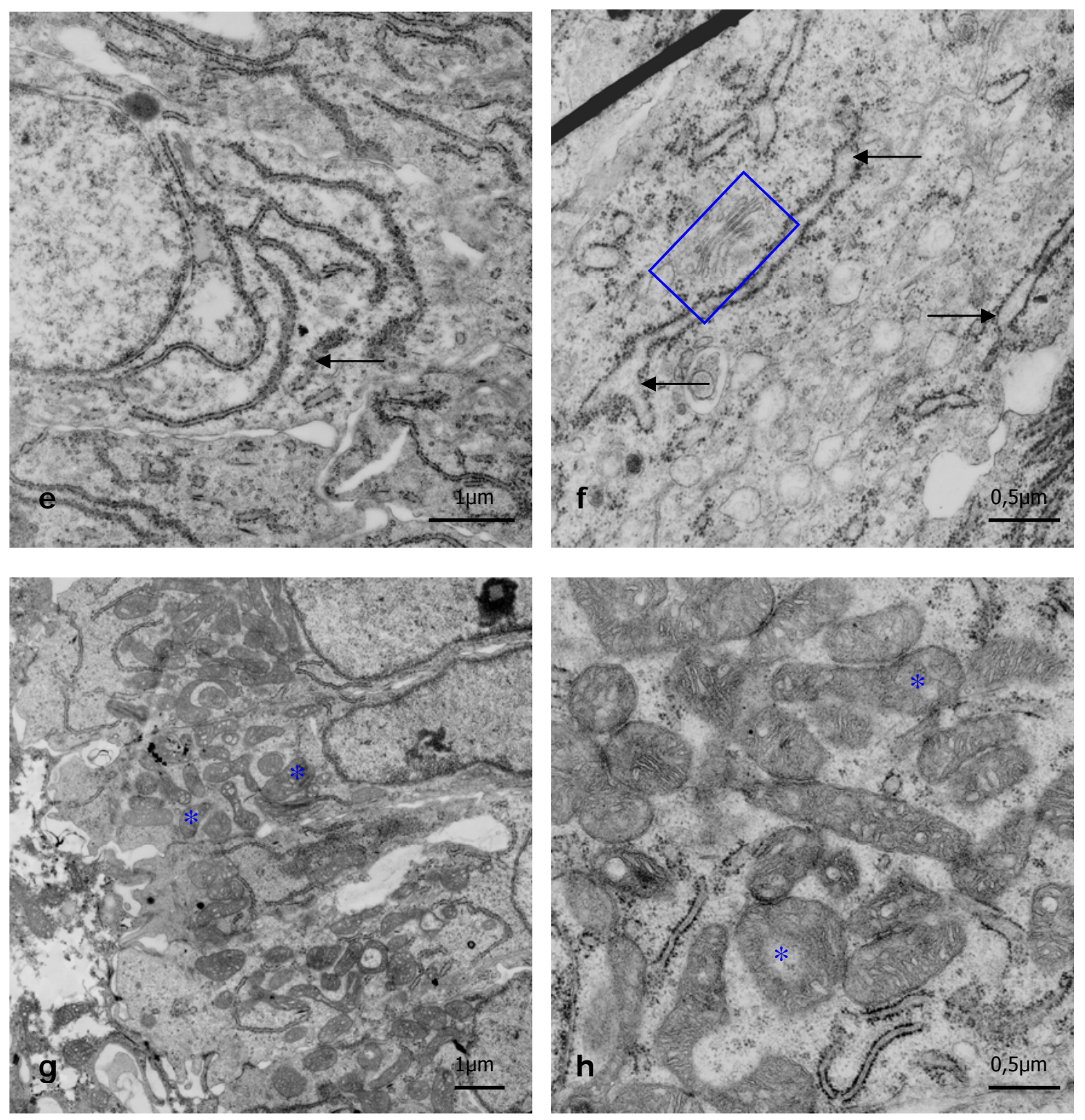

FIGURA 15 (e-h) - Corte ultrafino de ameloblasto secretor de rato recém-nascido do grupo de 100ppm. Observar: e-f) na região supranuclear, podem ser observados pequenos sáculos do aparelho de Golgi $(\square)$ e cisternas dilatadas de retículo endoplasmático rugoso (REG) (setas); gh) na região basal, a maioria das mitocôndrias (*) mostra-se mais dilatada, com as cristas menos organizadas que as observadas no grupo controle 
(verso do gloss paper) 
5.1.3.2 Grupo II: animais com sete dias de vida pósnatal

\subsection{Descrição do ameloblasto do grupo controle}

O ameloblasto secretor do grupo controle de ratos com sete dias de vida pós-natal observado no microscópio eletrônico de transmissão mostrou as mesmas características ultraestruturais observadas nos ratos recém-nascidos, ou seja, a região supranuclear até antes do início do processo de Tomes preenchida por muitas cisternas homogêneas e paralelas de retículo endoplasmático granular (REG) e por algumas formações de complexo de Golgi representados por pequenos dictiossomas com poucos sáculos paralelos e achatados (FIGURA 16a, b, c). Na região do processo de Tomes foram observados pequenos grânulos de secreção. O núcleo eucromático com nucléolo evidente ocupa a região suprabasal e grande quantidade de pequenas mitocôndrias arredondada, oval ou alongada ocupam a região basal (FIGURA $16 a)$.

Os ameloblastos em maturação, tanto de borda lisa quanto de borda rugosa, mostraram características normais. Por exemplo, o de borda lisa apresenta na região basal (FIGURA 17a-b) muitas mitocôndrias alongadas e arredondadas localizadas entre as invaginações do plasmalema basal e o núcleo mostra-se menor ou menos alongado, com cromatina mais densa que 0 observado no ameloblasto secretor. Na região média (FIGURA 17c-d) do ameloblasto de borda lisa observa-se menos REG que nos secretores e em seu lugar aparecem mitocôndrias, lisossomos, vacúolos digestivos e microfilamentos mais evidentes.

\subsection{Descrição do ameloblasto do grupo de 7ppm}

O ameloblasto secretor dos ratos com sete dias de vida pós-natal do grupo de 7ppm mostra vários vacúolos claros de vários tamanhos às vezes com material eletrondenso na região apical, imediatamente antes do processo de Tomes (FIGURA 18a). Os pequenos grânulos de secreção presentes no 
processo de Tomes entre porções de matriz interprismática parecem em quantidade e com morfologia similar à observada nos ameloblastos do grupo controle da mesma idade. Na região média e basal, o REG e as mitocôndrias de vários formatos não apresentaram alterações morfológicas (FIGURA 18b-c).

Os ameloblastos em maturação de borda lisa e no de borda rugosa mostraram, respectivamente, invaginações no plasmalema basal e apical. A quantidade e distribuição de REG, mitocôndrias, lisossomos e microfilamentos apresentaram-se nos padrões morfológicos de características normais.

\subsection{Descrição do ameloblasto do grupo de 100ppm}

O ameloblasto secretor dos ratos com sete dias de vida pós-natal do grupo de 100ppm mostra na região apical (FIGURA 19a) imediatamente antes do processo de Tomes vários vacúolos claros de vários tamanhos similares aos observados no grupo de 7ppm. Os grânulos de secreção observados no processo de Tomes não mostram anormalidades. As cisternas de REG dessa região mostram-se mais dilatas, com disposição espacial menos paralela que as observadas nos ameloblastos controles e 7ppm. Na região basal (FIGURA 19bc) não só o REG, mas também as mitocôndrias mostram-se mais dilatadas, estas últimas com maiores espaços entre as suas cristas. A retração entre a porção basal do ameloblasto e as células do estrato intermediário parece maior que a observada no grupo controle.

As imagens ultraestruturais observadas do ameloblasto em maturação de borda rugosa não sugeriram anormalidades morfológicas. O de borda lisa (FIGURA 20a-b) mostrou pequenas vesículas claras de pinocitose e figuras de endocitose eletrondensa em grande quantidade na região apical imediatamente próximo a matriz de esmalte. Essa grande quantidade de material na porção apical sugere uma velocidade reduzida de transporte e digestão do material endocitado. O REG e as mitocôndrias observados nesta região não mostram diferenças com os observados no grupo controle. Na região basal (FIGURA 20cd), as mitocôndrias, microfilamentos, núcleo e nucléolo parecem com características morfológicas normais. 

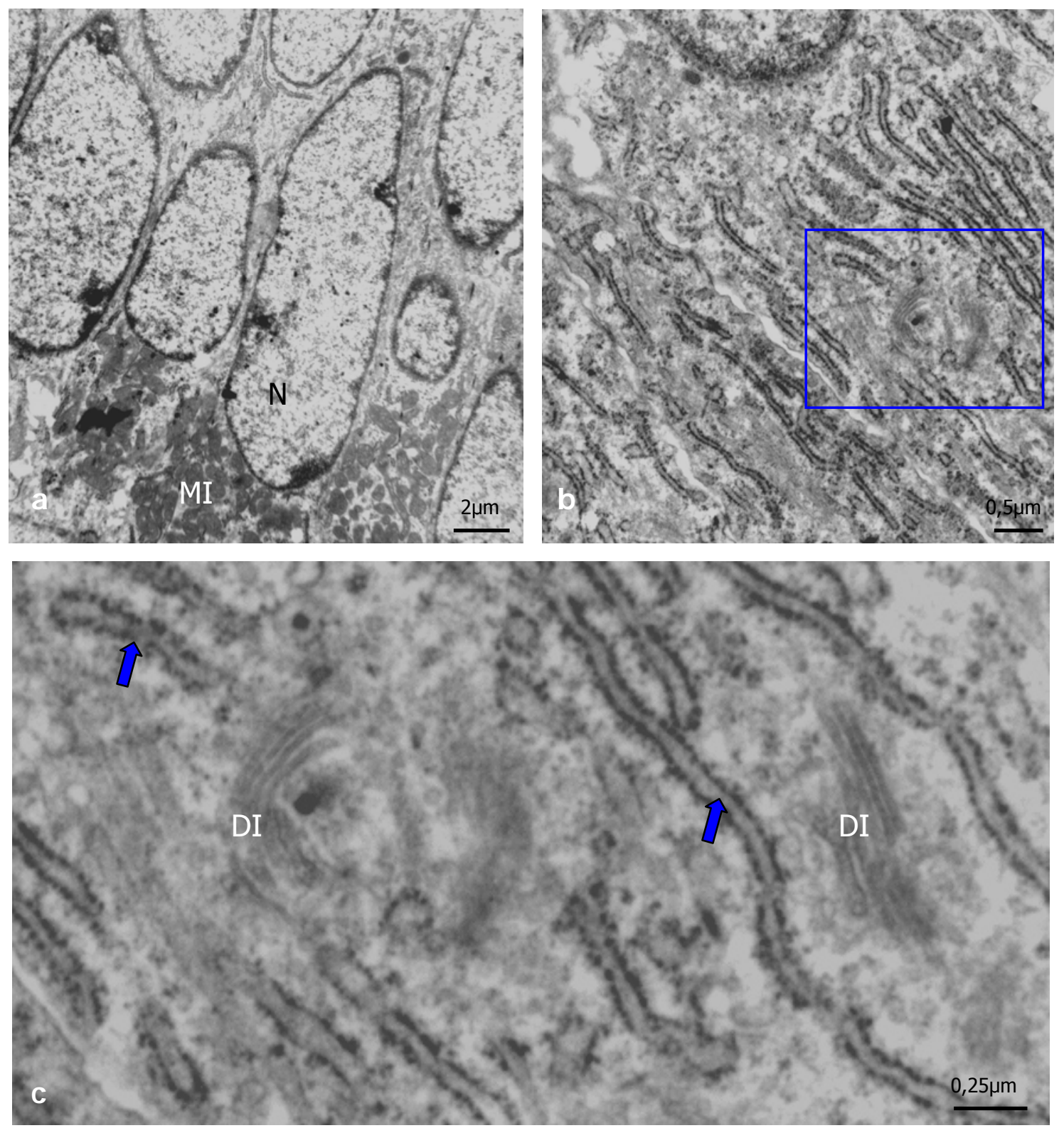

FI GURA 16 (a-c) - Corte ultrafino de ameloblasto secretor de rato com sete dias de vida pósnatal do grupo controle. Observar na região basal: a) grande quantidade de mitocôndrias (MI) e o núcleo (N) com morfologia preservada; b) as cisternas de REG paralelamente distribuídas e os pequenos dictiossomas ( $\square$ ) do complexo de Golgi de aspecto normal na região supranuclear; c) dictiossomos (DI) e REG (setas) num maior aumento da FIGURA 16b 
106

Resultados

(verso do gloss paper)

ב. 

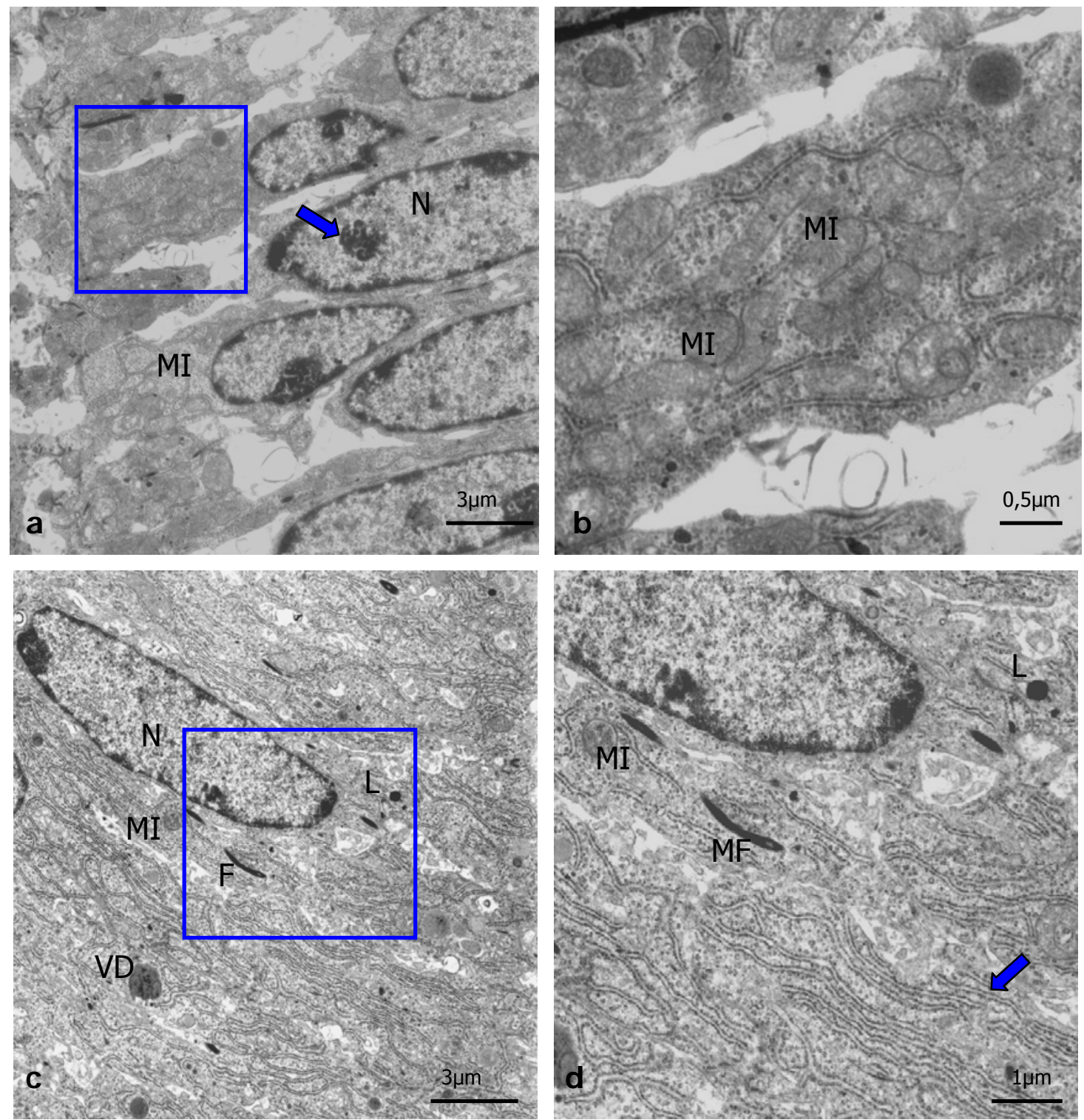

FIGURA 17 (a-d) - Corte ultrafino de ameloblasto na fase de maturação com borda lisa de rato com sete dias de vida pós-natal do grupo controle. Observar na região basal: a) as mitocôndrias (MI) alongadas e arredondadas, núcleo (N) e o nucléolo (seta) preservados; b) detalhe da FIGURA 17a, mitocôndrias (MI) entre as invaginações do plasmalena basal; c) microfilamentos (MF), mitocôndrias (MI), vacúolos digestivos (VD), lisossomos (L) e o núcleo (N) na região média com aspectos morfológicos normais; d) detalhe da FIGURA 17c, onde se observa REG (seta), microfilamentos (MF), mitocôndrias (MI), lisossomo (L) 
108

Resultados

(verso do gloss paper)

$\overline{ }$ 

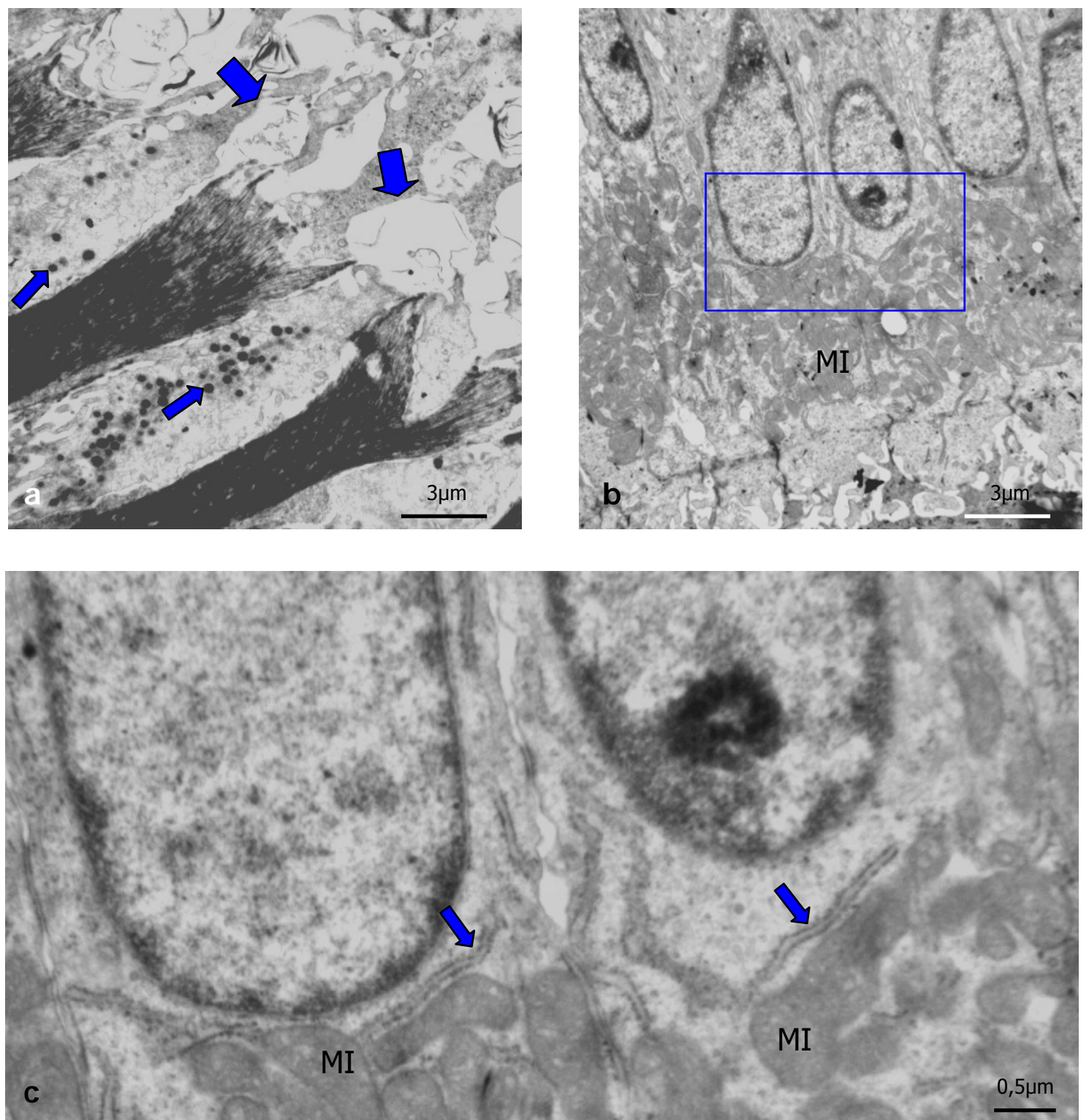

FI GURA 18 (a-c) - Corte ultrafino de ameloblasto secretor de rato com sete dias de vida pósnatal do grupo de 7ppm. Observar na região do processo de Tomes: a) vacúolos claros (setas largas) e entre a matriz de esmalte interprismático os pequenos grânulos de secreção (setas pequenas); b) uma grande quantidade de mitocôndrias (MI) normais de várias formas na região basal; c) ampliação da FIGURA 18b com mitocôndrias (MI) e REG (setas) de aspectos normais 
110

Resultados

(vverso do gloss paper)

" 

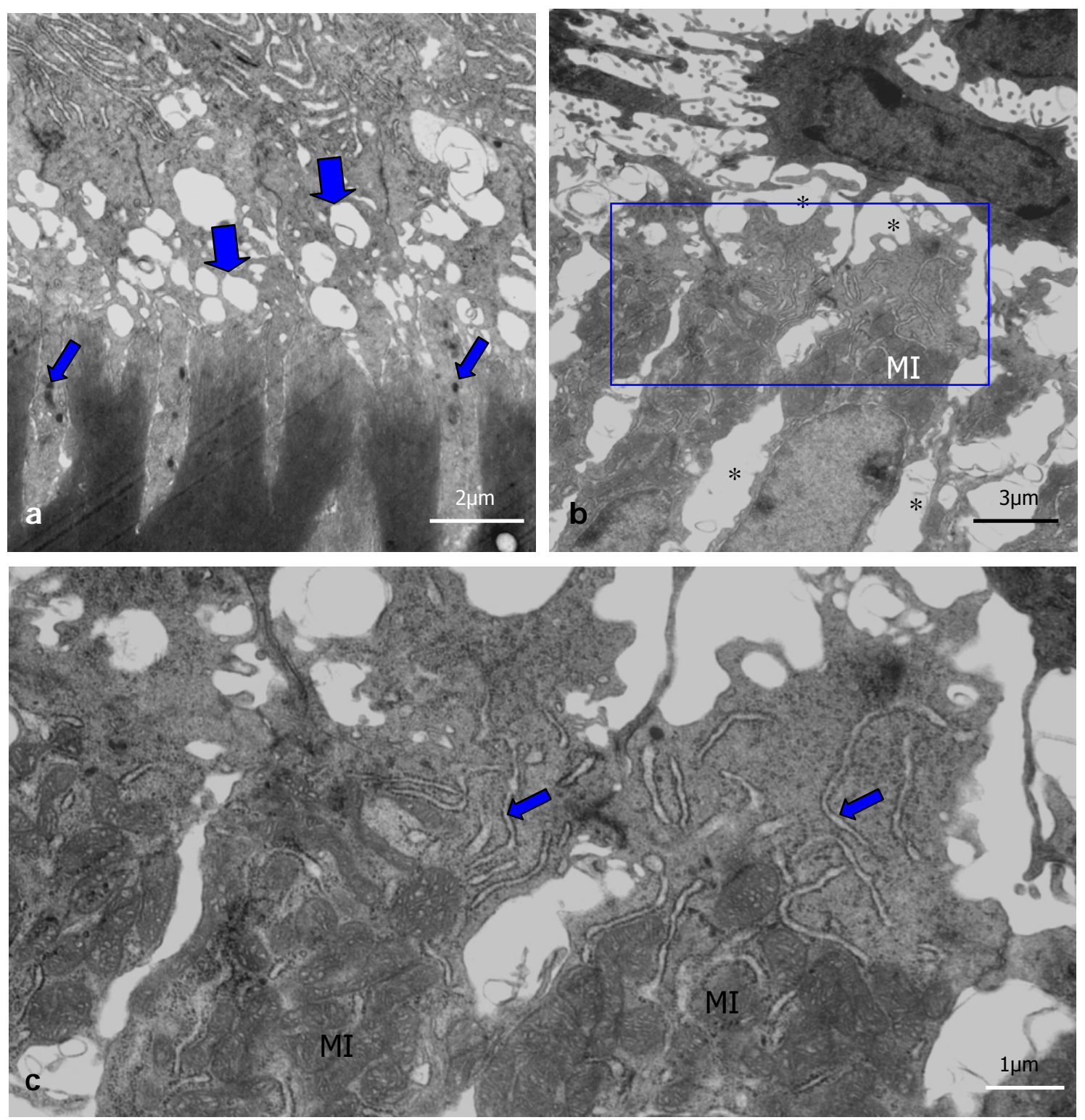

FI GURA 19 (a-c) - Corte ultrafino de ameloblasto secretor de rato com sete dias de vida pósnatal do grupo de 100ppm. Observar na região do processo de Tomes: a) poucos e pequenos grânulos de secreção (setas pequenas), vacúolos claros (setas largas) entre a matriz interprismática e cisternas de REG mais dilatadas com disposição aleatória em sua maioria na região média-apical; b) algumas mitocôndrias (MI) com aspecto dilatado, mostrando maior espaço entre as cristas e retração entre a porção basal dos ameloblastos e as células do estrato intermediários (*) na região basal; c) ampliação da FIGURA 19b, com REG (setas) e mitocôndrias (MI) de aspecto dilatado entre as invaginações do plasmalema basal (setas) 
112

Resultados

(verso do gloss paper)

$\overline{ }$ 

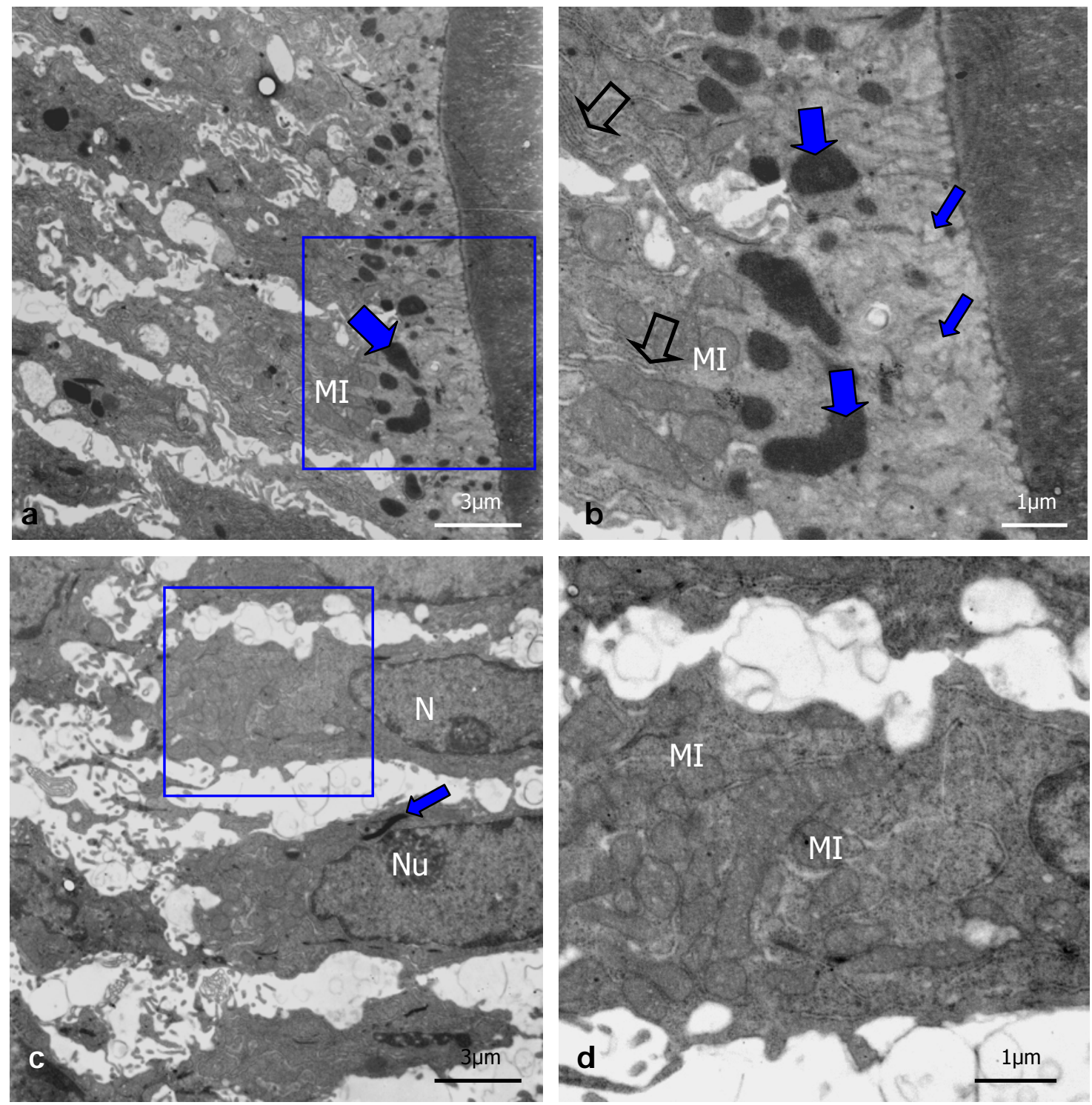

FI GURA 20 (a-d) - Corte ultrafino de ameloblasto na fase de maturação de borda lisa de rato com sete dias de vida pós-natal do grupo de 100ppm. Observar próximo à matriz na região apical: a) grandes vacúolos eletrondensos de endocitose (seta larga) ao lado de mitocôndrias (MI) normais; b) detalhe da FIGURA 20a, demonstrando em maior aumento de microvesículas claras de endocitose (setas pequenas) e grandes vacúolos de endocitose (setas largas), REG (setas vazadas) e mitocôndrias (MI); c) o núcleo $(\mathrm{N})$, nucléolo $(\mathrm{Nu})$ e microfilamentos (seta) normais na região basal; d) detalhe da FIGURA 20c com mitocôndrias (MI) de morfologia normal 
(vverso do glosss paper) 


\subsubsection{Grupo III: animais com 14 dias de vida pós-natal}

\subsection{Descrição do Ameloblasto do Grupo Controle}

O ameloblasto secretor de ratos com 14 dias de vida pós-natal do grupo controle observado no microscópio eletrônico de transmissão mostrou as mesmas características ultraestruturais observadas nos ratos recém-nascidos e nos de sete dias de vida pós-natal (FIGURAS 14, 16, 17). A região supranuclear até antes do início do processo de Tomes é preenchida por muitas cisternas homogêneas e paralelas de retículo endoplasmático granular (REG). Algumas formações de complexo de Golgi são representadas por pequenos dictiossomas com poucos sáculos paralelos e achatados. Na região do processo de Tomes, são observados pequenos grânulos de secreção. O núcleo eucromático com nucléolo evidente ocupa a região suprabasal. Na porção basal, existe uma grande quantidade de pequenas mitocôndrias de formato arredondado, oval ou alongado.

Os ameloblastos em maturação, tanto de borda lisa quanto de borda rugosa, mostraram características normais similares aos observados nos ratos do grupo de sete dias, lembrando que nos recém-nascidos esses ameloblastos ainda não estão presentes. As características morfológicas dos ameloblastos de borda lisa e de borda rugosa são as mesmas descritas nos animais adultos.

\subsection{Descrição do ameloblasto do grupo de 7ppm}

O ameloblasto secretor dos ratos com 14 dias de vida pós-natal do grupo de 7ppm de flúor mostra na região apical também vacúolos claros, como os observados nos ratos recém-nascidos e com sete dias de vida (FIGURA 18a). Os grânulos de secreção presentes no processo de Tomes são normais. Tanto na região supranuclear (FIGURA 21a), quanto na região basal (FIGURA 21b) a morfologia do REG, mitocôndrias, microfilamentos e núcleo também são normais. 
Os ameloblastos em maturação de borda lisa mostraram as invaginações no plasmalema basal, enquanto que os de borda rugosa as apresentaram na região apical. A quantidade e distribuição de REG, mitocôndrias, lisossomos e microfilamentos foram observadas dentro dos padrões morfológicos de características normais.

\subsection{Descrição do ameloblasto do grupo de 100ppm}

O ameloblasto secretor de ratos com 14 dias de vida pós-natal do grupo de 100ppm de flúor mostra também vacúolos claros de vários tamanhos e grânulos de secreção na região apical similares aos observados nos grupos experimentais de outras idades. Algumas cisternas de REG dessa região apical e outras da região central (FIGURA 22a, c) mostram-se preservadas, mas grande parte encontra-se com maior dilatação, muitas vezes preenchidas por material eletrondenso intracisternal e disposição espacial não paralela. A maioria dos pequenos dictiossomas de complexo de Golgi apresentou sáculos mais dilatados que os normais, estando localizados próximos ao plasmalema lateral. Na região basal (FIGURA 22b) as mitocôndrias mostram-se mais dilatadas, apresentando maior espaço entre as cristas mitocondriais.

As observações ultraestruturais do ameloblasto em maturação de borda lisa apresentam um padrão morfológico similar ao observado nos ratos com sete dias do grupo de 100ppm (FIGURA 20), destacando-se as figuras de matriz orgânica de esmalte endocitadas. No ameloblasto de borda rugosa (FIGURA 23a), está evidente uma grande quantidade de mitocôndrias dilatadas entre e abaixo das invaginações apicais. Na região basal e central (FIGURA 23b-c), 0 REG e o núcleo não mostram quaisquer alterações morfológicas que possam ser subjetivamente detectadas pela metodologia descritiva adotada. 

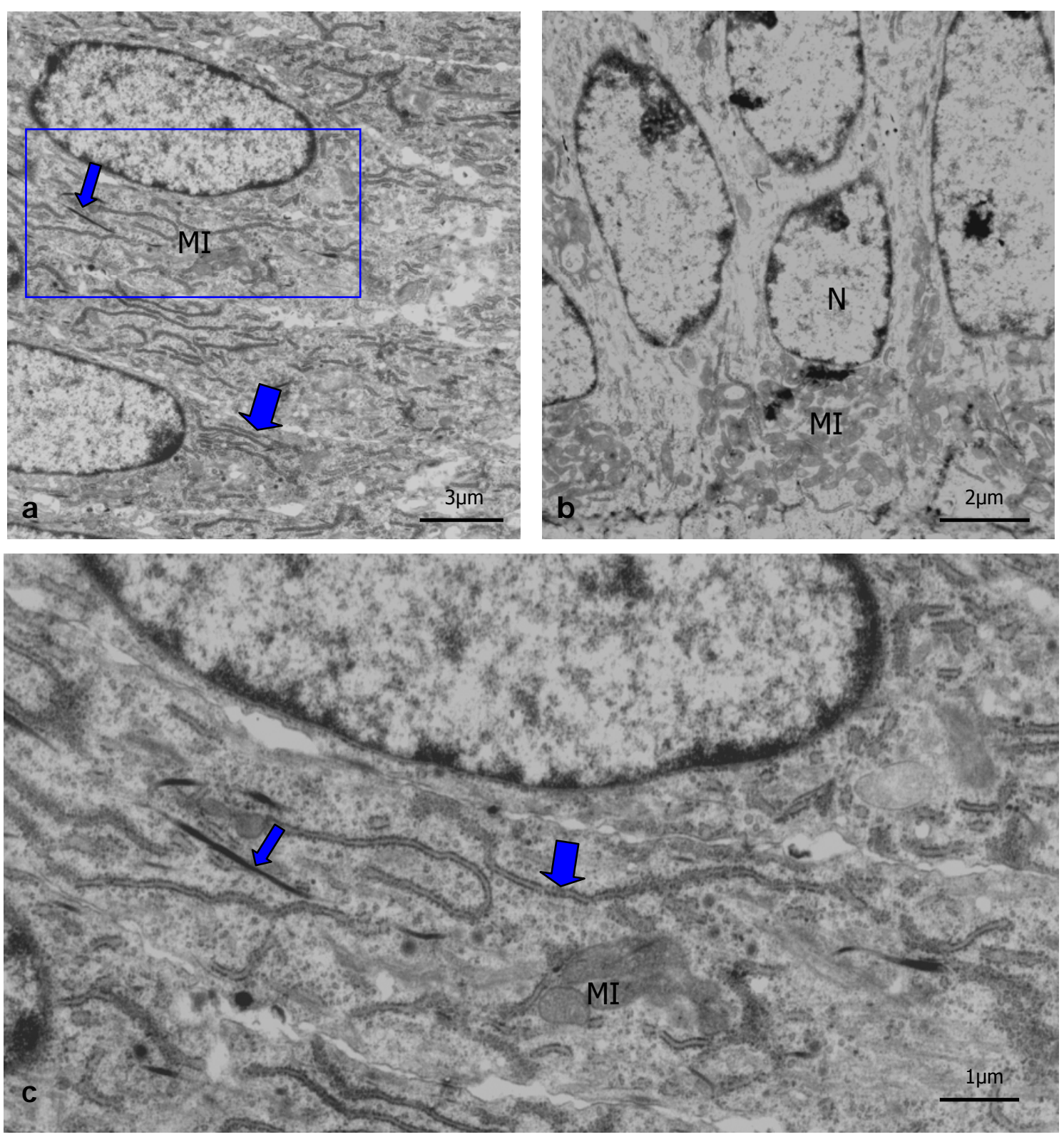

FIGURA 21 (a-c) - Corte ultrafino de ameloblasto secretor de rato com 14 dias de vida pósnatal do grupo de 7ppm. Observar na porção supranuclear: a) o REG (seta grande), pequenas mitocôndrias (MI) e microfilamentos (seta pequena) de aspectos morfológicos normais; $b$ ) pequenas mitocôndrias (MI) e o núcleo (N) de morfologia preservada na região basal; $\mathrm{c}$ ) destaque da FIGURA 21a onde pode ser observados cisternas de REG (seta grande), mitocôndrias (MI) e microfilamentos (seta pequena) 
118

Resultados

(verso do glosss paper)

ב. 

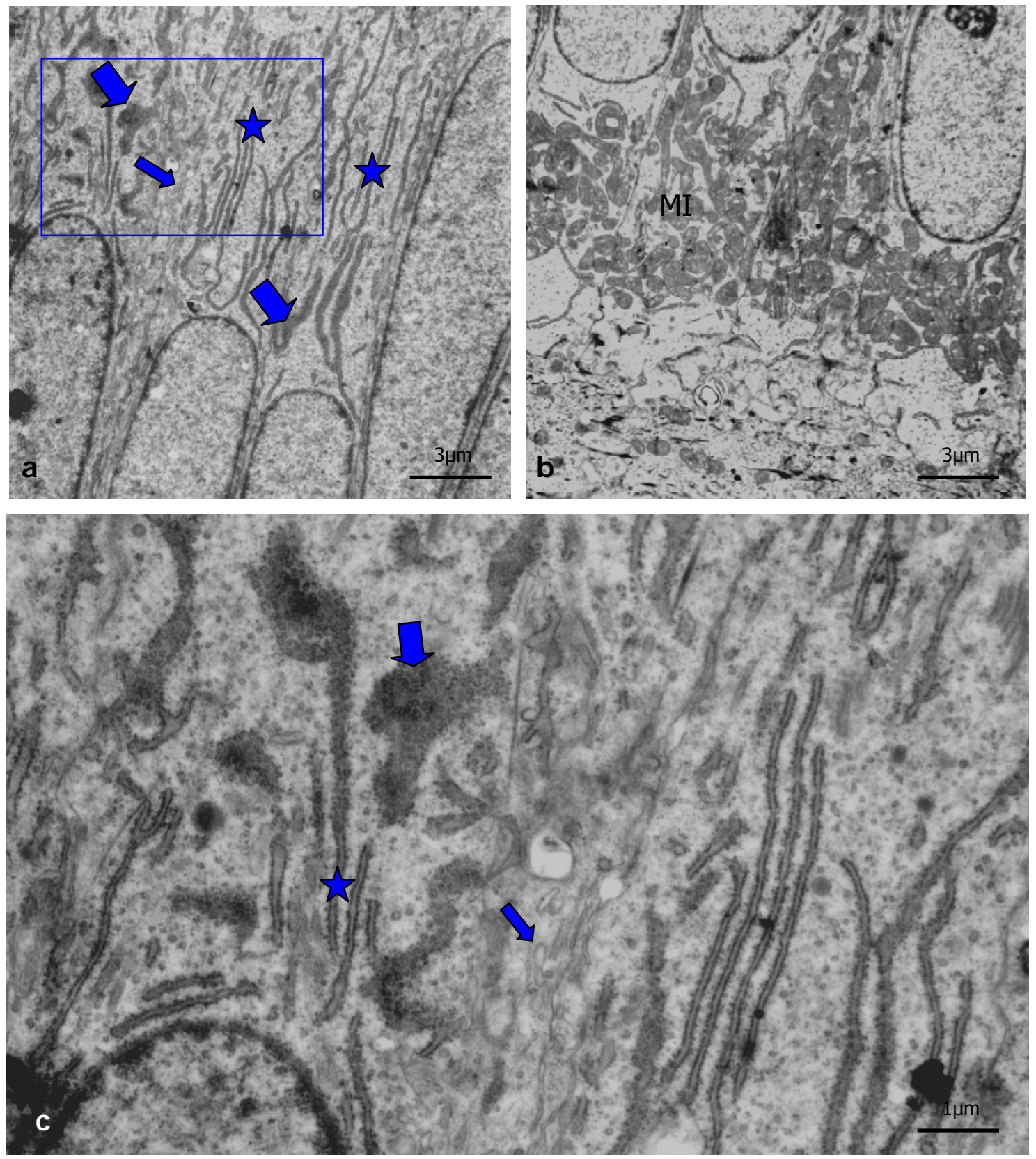

FIGURA 22 (a-c) - Corte ultrafino de ameloblasto secretor de rato com 14 dias de vida pósnatal do grupo de 100ppm. Observar na porção supranuclear: a) algumas cisternas de REG preservadas (estrelas) e outras dilatadas com material intracisternal (seta grande), pequenos dictiossomos de complexo de Golgi (seta pequena) localizados na maioria junto à porção próxima ao plasmalema lateral formados por pequenos sáculos dilatados; b) mitocôndrias (MI) de aspecto mais dilatado mostrando maiores espaços claros entre as cristas na porção basal; c) destaque da FIGURA 22a onde se observa cisternas de REG preservadas (estrela) e dilatadas preenchidas com material intracisternal (seta grande) e sáculos de Golgi (seta pequena) 
(verso do gloss paper) 

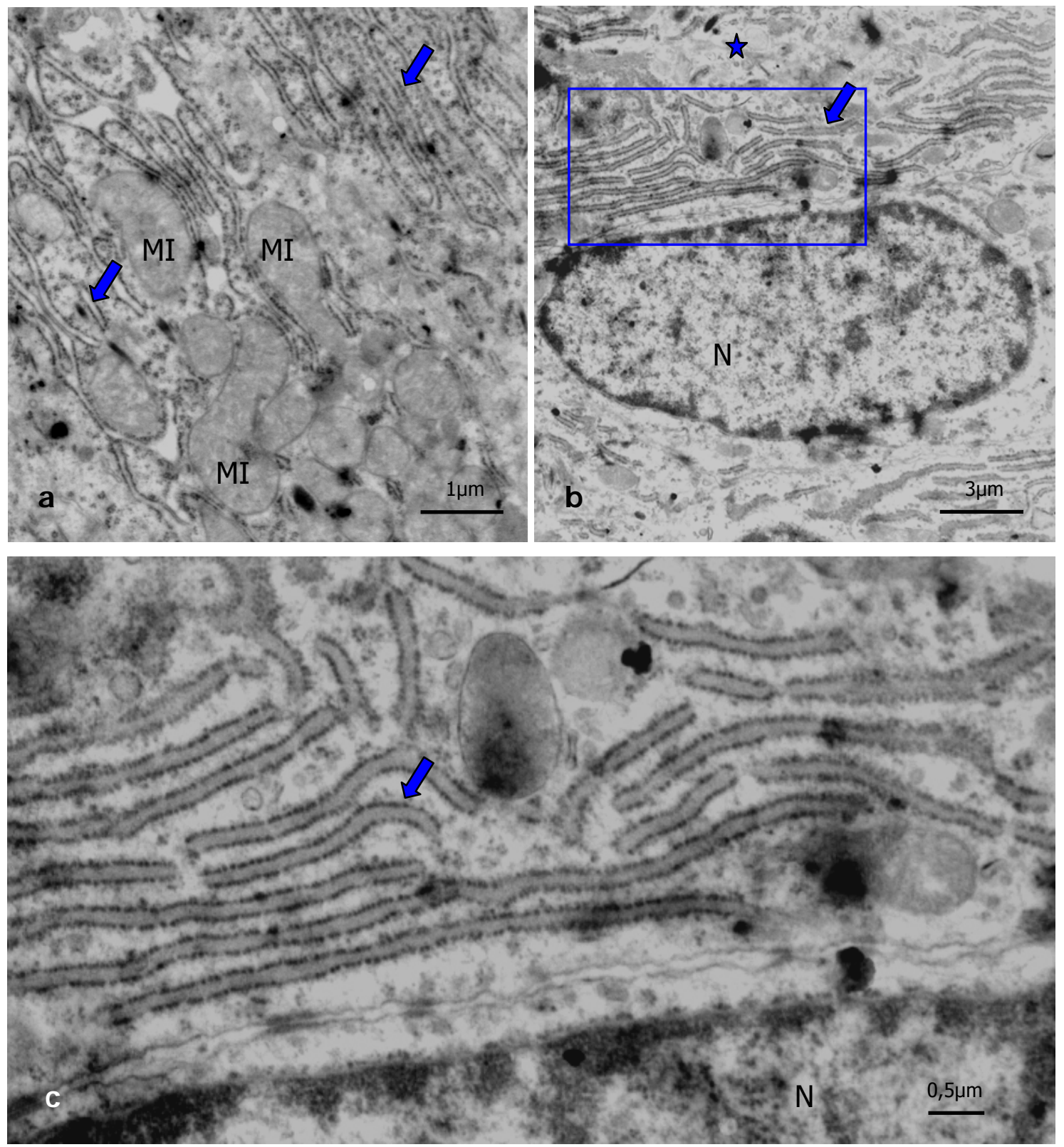

FI GURA 23 (a-c) - Corte ultrafino de ameloblasto na fase de maturação de borda rugosa de rato com 14 dias de vida pós-natal do grupo de 100ppm. Observar na porção apical: a) grande quantidade de mitocôndrias (MI) dilatadas e cisternas de REG (seta) preservadas; b) núcleo (N), REG (seta) com morfologia normal e possível região (estrela) do complexo de Golgi mal definida ou preservada na região média; c) destaque da FIGURA 23b, onde se observam cisternas de REG (seta) e parte do núcleo (N), ambos com aspecto normal 
(verso do gloss paper) 


\subsection{Resultados morfométricos}

\subsubsection{Comprimento da matriz do esmalte}

Para as medidas de comprimento da matriz do esmalte foram verificados o comprimento da matriz do esmalte retida durante a fase de secreção, após a fase de secreção (englobando a fase de transição e maturação) e o valor total de comprimento (correspondente à somatória dos valores obtidos na fase de secreção e após a mesma). A partir das medidas obtidas de comprimento em $\mu \mathrm{m}$ da matriz do esmalte, foram calculadas a média e o desvio-padrão para cada grupo a fim de se determinar variações entre as amostras. (TABELA 1).

Da análise da TABELA 1, pode-se constatar que:

\section{- nos animais recém-nascidos}

- não houve diferença estatística entre nenhum dos subgrupos avaliados.

- nos animais de sete dias

- na fase de secreção, houve uma redução de 14,38\% e 13,47\% no comprimento da matriz do subgrupo de 100ppm, respectivamente, em relação aos subgrupos controle e de 7ppm;

- após a fase de secreção, não houve diferenças estatísticas entre os subgrupos analisados;

- considerando o comprimento total de matriz retida na lâmina, o subgrupo de 100ppm apresentou, respectivamente, um valor 5,78\% e 5,02\% menor que o subgrupo controle e de 7ppm;

- nos animais de 14 dias

- na fase de secreção, foi observado no subgrupo de 7ppm que o comprimento foi, respectivamente, $16,47 \%$ e $18,53 \%$ maiores que os valores correspondentes ao grupo controle e de 100ppm; 
- após a fase de secreção, não houve diferenças estatisticamente significantes em relação ao comprimento da matriz;

- o comprimento total da matriz do subgrupo de 7ppm foi, respectivamente, $11,43 \%$ e $16,71 \%$ maior que o subgrupo controle e de $100 \mathrm{ppm}$.

TABELA 1 - Média e desvio-padrão do comprimento de matriz de esmalte (em $\mu \mathrm{m})$ dos grupos de tratamento com flúor para ratos com 0, 7 e 14 dias de vida pós-natal $(n=5)$

\begin{tabular}{|c|c|c|c|}
\hline \multicolumn{4}{|c|}{ Recém-nascidos } \\
\hline & Oppm & 7ppm & 100ppm \\
\hline Fase de secreção & $1833,31 \pm 299,46$ & $1856,30 \pm 181,79$ & $1615,91 \pm 198,01$ \\
\hline \multicolumn{4}{|c|}{7 dias } \\
\hline & Oppm & 7ppm & 100ppm \\
\hline Fase de secreção & $\begin{array}{c}4733,57 \pm 393,50 \\
a^{*}\end{array}$ & $\begin{array}{c}4683,87 \pm 177,82 \\
a\end{array}$ & $\begin{array}{c}4052,92 \pm 311,94 \\
b\end{array}$ \\
\hline $\begin{array}{l}\text { Após a fase de } \\
\text { secreção }\end{array}$ & $2852,43 \pm 222,85$ & $2841,48 \pm 275,74$ & $3094,39 \pm 157,41$ \\
\hline Comprimento total & $\begin{array}{c}7585,99 \pm 398,61 \\
a\end{array}$ & $\begin{array}{c}7525,35 \pm 368,15 \\
a\end{array}$ & $\begin{array}{c}7147,31 \pm 423,39 \\
b\end{array}$ \\
\hline \multicolumn{4}{|c|}{14 dias } \\
\hline & Oppm & 7ppm & 100ppm \\
\hline Fase de secreção & $\begin{array}{c}4622,38 \pm 351,43 \\
a\end{array}$ & $\begin{array}{c}5383,64 \pm 471,77 \\
b\end{array}$ & $\begin{array}{c}4541,83 \pm 249,80 \\
a\end{array}$ \\
\hline $\begin{array}{l}\text { Após a fase de } \\
\text { secreção }\end{array}$ & $3080,11 \pm 348,38$ & $3313,09 \pm 515,90$ & $3326,43 \pm 171,85$ \\
\hline Comprimento total & $\begin{array}{c}7702,49 \pm 535,31 \\
a\end{array}$ & $\begin{array}{c}8696,73 \pm 143,53 \\
b\end{array}$ & $\begin{array}{c}7868,26 \pm 361,02 \\
a\end{array}$ \\
\hline
\end{tabular}

* Letras iguais ou ausência de letras mostram ausência de diferença estatística $(p>0,05)$ Letras diferentes mostram diferença estatisticamente significante $(p<0,05)$ 


\subsubsection{Altura e volume dos ameloblastos}

Nas medidas morfométricas dos ameloblastos, foram realizados os cálculos e obtidos a média e o desvio-padrão para cada grupo. As médias e desvio padrão de altura celular, densidade de volume nuclear e citoplasmático, volume nuclear e citoplasmático dos animais de 0, 7 e 14 dias de vida pós-natal encontram-se respectivamente nas TABELAS 2, 3 e 4.

Da análise das TABELAS 2, 3 e 4, pode-se constatar que:

- o flúor não interferiu na altura dos ameloblastos em nenhuma das fases, dentro da mesma idade;

- no grupo de sete dias, o volume citoplasmático do ameloblasto secretor do subgrupo de $100 \mathrm{ppm}$ foi $23,80 \%$ e $17,63 \%$ menor que os valores observados respectivamente para os subgrupos de zero e $7 \mathrm{ppm}$ de flúor;

- no grupo de 14 dias, o volume citoplasmático do ameloblasto secretor do subgrupo de $100 \mathrm{ppm}$ foi $24,75 \%$ e $16,09 \%$ menor que os valores observados respectivamente nos subgrupos de zero e 7ppm de flúor;

- o volume do núcleo e do citoplasma dos ameloblastos da fase de maturação não mostraram diferenças estatisticamente significantes em função do tratamento com o flúor em nenhuma das idades estudadas. 
TABELA 2 - Média e desvio-padrão dos parâmetros morfométricos obtidos para ameloblastos do grupo de ratos recém-nascidos $(n=5)$

\begin{tabular}{cccc}
\hline Fase de secreção & Oppm & 7ppm & 100ppm \\
\hline $\begin{array}{c}\text { Altura celular } \\
(\mathrm{em} \mu \mathrm{m})\end{array}$ & $63,94 \pm 2,38$ & $63,89 \pm 2,64$ & $63,35 \pm 2,35$ \\
$\begin{array}{c}\text { Densidade de volume } \\
\text { nuclear (em \%) }\end{array}$ & $27,32 \pm 2,27$ & $27,32 \pm 2,31$ & $27,81 \pm 2,22$ \\
$\begin{array}{c}\text { Densidade de volume } \\
\text { citoplasmático (em \%) } \\
\text { Volume nuclear } \\
\left(\text { em } \mu m^{3}\right)\end{array}$ & $72,68 \pm 2,27$ & $72,30 \pm 2,31$ & $72,19 \pm 2,22$ \\
$\begin{array}{c}\text { Volume citoplasmático } \\
\left(\text { em } \mu m^{3}\right)\end{array}$ & $1195,03 \pm 103,01$ & $1167,71 \pm 53,42$ & $1148,22 \pm 88,30$ \\
\hline
\end{tabular}

* Letras iguais ou ausência de letras mostram ausência de diferença estatística $(p>0,05)$

Letras diferentes mostram diferença estatisticamente significante $(p<0,05)$ 
TABELA 3 - Média e desvio-padrão dos parâmetros morfométricos obtidos para ameloblastos no grupo de ratos com sete dias de vida pós-natal $(n=5)$

\begin{tabular}{|c|c|c|c|}
\hline Fase de secreção & Oppm & 7ppm & 100ppm \\
\hline $\begin{array}{l}\text { Altura celular } \\
\text { (em } \mu \mathrm{m})\end{array}$ & $69,50 \pm 4,37$ & $70,08 \pm 4,76$ & $69,50 \pm 3,78$ \\
\hline Densidade de volume & $19,28 \pm 2,42$ & $20,38 \pm 3,02$ & $23,50 \pm 2,40$ \\
\hline nuclear (em \%) & a* & a & $b$ \\
\hline Densidade de volume & $80,72 \pm 2,42$ & $79,62 \pm 3,02$ & $76,50 \pm 2,40$ \\
\hline citoplasmático (em \%) & $a$ & a & $b$ \\
\hline $\begin{array}{l}\text { Volume nuclear } \\
\qquad\left(\mathrm{em} \mu \mathrm{m}^{3}\right)\end{array}$ & $444,40 \pm 64,09$ & $439,63 \pm 62,40$ & $436,22 \pm 60,04$ \\
\hline $\begin{array}{l}\text { Volume citoplasmático } \\
\qquad\left(\mathrm{em} \mu \mathrm{m}^{3}\right)\end{array}$ & $\begin{array}{c}1867,50 \pm 152,93 \\
a\end{array}$ & $\begin{array}{c}1727,53 \pm 183,76 \\
a\end{array}$ & $\begin{array}{c}1423,05 \pm 87,11 \\
\text { b }\end{array}$ \\
\hline Fase de maturação & Oppm & 7ppm & 100ppm \\
\hline $\begin{array}{l}\text { Altura celular } \\
\qquad(\mathrm{em} \mu \mathrm{m})\end{array}$ & $45,50 \pm 3,40$ & $44,40 \pm 2,80$ & $43,94 \pm 2,58$ \\
\hline $\begin{array}{l}\text { Densidade de volume } \\
\text { nuclear (em \%) }\end{array}$ & $20,64 \pm 2,41$ & $20,64 \pm 2,16$ & $21,83 \pm 2,56$ \\
\hline $\begin{array}{l}\text { Densidade de volume } \\
\text { citoplasmático (em \%) }\end{array}$ & $79,36 \pm 2,41$ & $79,36 \pm 2,16$ & $78,17 \pm 2,56$ \\
\hline $\begin{array}{l}\text { Volume nuclear } \\
\qquad\left(\mathrm{em} \mu \mathrm{m}^{3}\right)\end{array}$ & $294,88 \pm 63,73$ & $286,27 \pm 51,73$ & $284,36 \pm 48,86$ \\
\hline $\begin{array}{l}\text { Volume citoplasmático } \\
\qquad\left(\mathrm{em} \mu \mathrm{m}^{3}\right)\end{array}$ & $1136,86 \pm 77,05$ & $1103,87 \pm 120,81$ & $1022,11 \pm 107,92$ \\
\hline
\end{tabular}

* Letras iguais ou ausência de letras mostram ausência de diferença estatística $(p>0,05)$

Letras diferentes mostram diferença estatisticamente significante $(p<0,05)$ 
TABELA 4 - Média e desvio padrão dos parâmetros morfométricos obtidos para ameloblastos no grupo de ratos com 14 dias de vida pós-natal $(n=5)$

\begin{tabular}{|c|c|c|c|}
\hline Fase de secreção & Oppm & 7ppm & 100ppm \\
\hline $\begin{array}{l}\text { Altura celular } \\
\qquad(\mathrm{em} \mu \mathrm{m})\end{array}$ & $74,28 \pm 3,42$ & $73,71 \pm 3,64$ & $72,63 \pm 4,18$ \\
\hline Densidade de volume & $18,44 \pm 2,26$ & $19,99 \pm 3,43$ & $22,49 \pm 3,40$ \\
\hline nuclear (em \%) & $a^{*}$ & a & $b$ \\
\hline Densidade de volume & $81,56 \pm 2,26$ & $80,01 \pm 3,43$ & $77,51 \pm 3,40$ \\
\hline citoplasmático (em \%) & $\mathrm{a}$ & a & b \\
\hline $\begin{array}{l}\text { Volume nuclear } \\
\qquad\left(\mathrm{em} \mu \mathrm{m}^{3}\right)\end{array}$ & $428,48 \pm 67,90$ & $425,10 \pm 62,33$ & $416,06 \pm 64,35$ \\
\hline $\begin{array}{l}\text { Volume citoplasmático } \\
\qquad\left(\mathrm{em} \mu \mathrm{m}^{3}\right)\end{array}$ & $\begin{array}{c}1905,76 \pm 181,25 \\
a\end{array}$ & $\begin{array}{c}1709,20 \pm 174,46 \\
a\end{array}$ & $\begin{array}{c}1434,18 \pm 43,99 \\
b\end{array}$ \\
\hline Fase de maturação & Oppm & 7ppm & 100ppm \\
\hline $\begin{array}{l}\text { Altura celular } \\
\text { (em } \mu \mathrm{m})\end{array}$ & $42,07 \pm 3,88$ & $41,53 \pm 3,90$ & $38,58 \pm 4,18$ \\
\hline $\begin{array}{l}\text { Densidade de volume } \\
\text { nuclear (em \%) }\end{array}$ & $21,94 \pm 2,90$ & $20,30 \pm 3,01$ & $21,97 \pm 2,84$ \\
\hline $\begin{array}{l}\text { Densidade de volume } \\
\text { citoplasmático (em \%) }\end{array}$ & $78,06 \pm 2,90$ & $79,70 \pm 3,01$ & $78,03 \pm 2,84$ \\
\hline $\begin{array}{l}\text { Volume nuclear } \\
\qquad\left(\mathrm{em} \mu \mathrm{m}^{3}\right)\end{array}$ & $284,91 \pm 51,57$ & $282,29 \pm 51,09$ & $281,77 \pm 48,57$ \\
\hline $\begin{array}{l}\text { Volume citoplasmático } \\
\qquad\left(\mathrm{em} \mu \mathrm{m}^{3}\right)\end{array}$ & $1019,63 \pm 115,60$ & $1118,42 \pm 148,01$ & $1002,35 \pm 45,11$ \\
\hline
\end{tabular}

* Letras iguais ou ausência de letras mostram ausência de diferença estatística $(p>0,05)$ Letras diferentes mostram diferença estatisticamente significante $(p<0,05)$ 
130

Discussão 


\section{Discussão}

Não existe dúvida a respeito da importância do flúor no controle da cárie dentária. Porém, devido ao seu uso indevido, o flúor pode levar a várias alterações celulares e na matriz de esmalte, levando à fluorose que aparece nos resultados epidemiológicos de várias pesquisas realizadas em diferentes regiões do mundo (BUDIPRAMANA et al. ${ }^{22}$, 2002; BURT; KEELS; HELLER ${ }^{23}$, 2003; CHOUBISA; CHOUBISA; CHOUBISA ${ }^{30}$, 2001) e no Brasil (BRANDÃO et al. ${ }^{19}$, 2002; CANGUSSU et al. ${ }^{26}$, 2002; MENEZES et al. ${ }^{113}$, 2002). Assim sendo, a fluorose está associada, principalmente, à incapacidade de se controlar a ingestão de flúor das várias fontes oferecida no dia-a-dia, que no somatório leva a uma dosagem tóxica (BUZALAF et al. ${ }^{25}$, 2002; JACKSON et al. ${ }^{86}, 2002$; LIMA; CURY ${ }^{104}$, 2001). O estabelecimento de uma conduta profilática universal para solucionar este problema ainda não foi encontrado. Para isto é necessária a compreensão da patogenia multifatorial da fluorose. Se isso definitivamente for esclarecido talvez métodos educacionais ou farmacológicos profiláticos e sanitários mais simples podem auxiliar a Saúde Pública a adotar métodos mais eficazes de controle.

Por motivos éticos, os estudos em humanos não permitem simular situações experimentais para buscar 0 entendimento das alterações morfológicas e bioquímicas durante o desenvolvimento da fluorose. Por isso, utilizam-se modelos experimentais em animais. Especialmente, o incisivo de rato é um dos modelos mais utilizados, por apresentar um crescimento contínuo, onde todas as fases da amelogênese podem ser observadas ao mesmo tempo (MATSUO et al. ${ }^{112}$, 1996; RIBEIRO; ASSIS; HIROTA ${ }^{140}, 2001$; SMITH; NANCI; DENBESTEN ${ }^{164}$, 1993).

O conhecimento do momento em que o flúor afeta de forma mais intensa o esmalte pode ser considerado de extrema importância na minimização dos riscos para o desenvolvimento da fluorose (AOBA; FEJERSKOV ${ }^{6}, 2002$ ). 0 risco de fluorose parece ser menor quando a exposição ocorre apenas na fase 
de secreção, sendo maior quando a exposição ocorre tanto na fase de secreção quanto na fase de maturação (incluindo obviamente a fase de transição entre ambas) (DENBESTEN ${ }^{42}$, 1999; DENBESTEN ${ }^{43}$, 1999; DENBESTEN; THARIANI ${ }^{47}$, 1992; HOROWITZ $\left.{ }^{79}, 1989\right)$.

Em animais adultos, a fase de secreção parece ser mais afetada quando o esmalte é exposto a níveis elevados de flúor na forma aguda (como na utilização de suplementos de flúor, como a aplicação tópica de fluoretos). Por outro lado, a fase de maturação será mais afetada na utilização de dosagens crônicas de flúor. É importante lembrar que o processo de mineralização do esmalte ocorre principalmente durante a fase de maturação, portanto, para reduzir a risco de fluorose, a exposição a fluoretos sistêmicos deveria ocorrer apenas após a irrupção dentária para um efeito benéfico com menor risco (DENBESTEN; THARIANI ${ }^{47}$, 1992; DENBESTEN ${ }^{43}$, 1999).

Em relação aos estádios mais avançados da amelogênese, vários trabalhos realizados demonstraram a influência do flúor na matriz do esmalte e nas alterações morfológicas em ameloblastos (KRUGER ${ }^{94}$, 1968; KRUGER ${ }^{96}$, 1970; MÖRNSTAD; HAMMARSTRÖM ${ }^{117}$ ，1978; NEIMAN; EISENMANN ${ }^{123}$, 1975; NORDLUND; EKSTRAND; HAMMARSTRÖM ${ }^{126}, 1986$; NORDLUND et al. ${ }^{127}, 1986$; WALTON; EISENMANN ${ }^{178}$, 1974).

Segundo vários autores, a condição magna na etiopatogenia da fluorose parece ser a retenção de proteínas do esmalte, representada principalmente pelas amelogeninas, durante a mineralização (ASSIS et al. ${ }^{12}$, 1999; DENBESTEN $^{41}$ ， 1986; DENBESTEN; CRENSHAW ${ }^{44}$ ， 1984; DENBESTEN; THARIANI ${ }^{47}$, 1992; DENBESTEN; CRENSHAW; WILSON ${ }^{48}$, 1985; LIMEBACK $^{105}$, 1994; OLIVEIRA ${ }^{128}$, 1988; RICHARDS ${ }^{141}$, 1990; SMITH; NANCI; DENBESTEN ${ }^{164}$, 1993; ZHOU; ZAKI; EISENMANN ${ }^{185}$, 1996).

A matriz do esmalte que, frente à fluorose, mineraliza-se sem a apropriada nucleação e alongamento dos cristais gera uma estrutura porosa com excesso de componentes protéicos. As proteínas retidas nesse tipo de matriz podem ser identificadas, por exemplo, por meio de imuno-histoquímica, onde as amelogeninas podem ser marcadas com anticorpos primários antiamelogeninas e analisadas em microscopia óptica de luz ou eletrônica 
(DIEKWISCH et al. ${ }^{51}, 1997$; NANCI et al. ${ }^{122}, 1998$; SIMMER ${ }^{155}$, 1995; SIMMER et al. ${ }^{158}$, 1994).

Como as amelogeninas perfazem mais de $90 \%$ da matriz secretada, a correlação entre as propriedades das amelogeninas e o mecanismo pelo qual se dá a fluorose dentária tornou-se uma peça chave para o entendimento da sua patogenia. Para tanto, houve a necessidade de padronização e reprodutibilidade experimental da fluorose, o que levou à proposição de diferentes modelos experimentais, dentre os quais os roedores (RICHARDS ${ }^{141}, 1990$ ).

No passado, as pesquisas em animais nesta área eram questionadas devido ao fato das doses administradas serem maiores que as doses consumidas por humanos. Isto poderia fazer com que as alterações produzidas não fossem relevantes para a comparação em humanos. Entretanto, inúmeros estudos realizados nas últimas décadas com dosagens mais altas têm demonstrado que as lesões fluoróticas e concentrações plasmáticas observadas em animais são da mesma magnitude que aquelas observadas em humanos (AOBA; FEJERSKOV ${ }^{6}, 2002$ ).

Desta forma, para que as lesões produzidas em animais pudessem mimetizar as humanas, as doses de flúor ingeridas deveriam ser proporcionalmente similares. Entretanto, as diferenças entre espécies não invalidam os resultados experimentais, principalmente se tais diferenças forem previsíveis e mensuráveis. Entre ratos e homens, o índice metabólico dos dentes é obviamente incompatível, além disso, o desenvolvimento dentário é bem mais curto no rato e, portanto, requer doses maiores de flúor para afetar o incisivo do rato. Daí a necessidade de doses bem mais altas para que haja distúrbios nos dentes de roedores. Um parâmetro que pode ser quantificado e correlacionado ao grau de agressão ocasionado pelo flúor, em qualquer espécie estudada, é a concentração desse composto no plasma (RICHARDS ${ }^{141}$, 1990).

Assim, na atual pesquisa, a dose fisiológica utilizada foi mais alta que a administrada em humanos, pois segundo FEJERSKOV et al. ${ }^{64}, 1979$, embora as lesões causadas por doses únicas ou múltiplas sejam semelhantes no rato e no homem, são necessárias doses de 10 a 50 vezes maiores em ratos. A quantidade de flúor utilizada também foi utilizada por seguir os valores 
sugeridos por outros trabalhos realizados anteriormente por $\operatorname{COSTA}^{33}, 2000$, RIBEIRO $^{139}$, 2001 e SMITH; NANCI; DENBESTEN ${ }^{164}, 1993$.

Vale lembrar também que todas as mães receberam ainda ração da marca Purina ad libitum, a qual apresentava um teor de flúor de aproximadamente $40 \mu \mathrm{g} / \mathrm{g}$, conforme relatado por CARVALHO ${ }^{27}$, 2005. A quantidade de água ingerida pelas mães dos animais utilizados no experimento não foram quantificadas. Estudos semelhantes realizados por $\operatorname{COSTA}^{33}, 2000 \mathrm{e}$ RIBEIRO ${ }^{139}$, 2001, não verificaram diferenças na quantia de líquido consumido por animais adultos que receberam 0, 7 ou 100ppm de flúor.

\subsection{Considerações sobre os resultados obtidos na análise morfológica em microscopia óptica e análise imuno-histoquímica para amelogenina}

A microscopia óptica revelou os germes dos incisivos de ratos recémnascidos circunscritos por tecido conjuntivo periodontal associados ao osso alveolar. Os aspectos microscópicos subjetivos observados em Hematoxilina e Eosina (H.E.) foram similares tanto no grupo controle quanto nos experimentais. Da porção proliferativa diferenciam-se ameloblastos que produzem uma matriz de esmalte homogênea que aumenta em espessura quanto mais coronal.

A análise morfológica da amelogenina mostrou um sinal imunohistoquímico intenso (pontual ou homogêneo) por toda a matriz do esmalte dos incisivos, sendo menor na região central e aumentando moderadamente em direção da junção amelodentinária, onde a marcação foi a mais intensa.

A marcação do material acumulado na junção amelodentinária também foi observada por outros autores tanto em microscopia óptica (ORSINI et al. ${ }^{129}$, 2001; YAMAMOTO et al. $\left.{ }^{184}, 1997\right)$, quanto em microscopia eletrônica (NANCI et al. ${ }^{122}$, 1998). Este padrão de marcação sugere que as formas intactas de amelogeninas podem apresentar uma distribuição complexa no esmalte e não apenas distribuídas uniformemente por toda matriz.

Também houve um sinal moderado na porção apical do citoplasma dos ameloblastos. No início da produção da matriz do esmalte, o padrão de 
marcação puntiforme intenso no citoplasma foi semelhante tanto no grupo controle, quanto nos experimentais. Esse tipo de marcação imuno-histoquímica também foi observado no citoplasma de pré-ameloblastos e ameloblastos de germes de incisivos e molares de ratos na primeira semana de vida pós-natal por INAI et al. ${ }^{84}, 1992$, INAI et al. ${ }^{85}, 1991$, TABATA et al. ${ }^{169}, 1996$ e YAMAMOTO et al. ${ }^{184}, 1997$.

Em condições normais, estudos que utilizaram técnicas imunohistoquímicas para amelogenina mostraram que durante a fase pré-secretora, existe um aumento na marcação ao redor do retículo endoplasmático rugoso, complexo de Golgi e dos grânulos de secreção. Durante a diferenciação dos odontoblastos e antes da destruição da membrana basal, uma marcação dispersa pode ser observada ao redor da matriz extracelular em formação. No início da fase de secreção, os anticorpos antiamelogenina demonstram intensa marcação no material extracelular denso localizado entre as células na região distal e nuclear, e também ao redor de lisossomos escuros (ARANA-CHAVEZ; NANCI ${ }^{10}, 2001$; INAGE et al. ${ }^{82}, 1989 ;$ NANCI et al. $\left.{ }^{122}, 1998\right)$. Durante a fase de secreção, os ameloblastos secretores mostram imunorreatividade no retículo endoplasmático rugoso, complexo de Golgi, grânulos de secreção, corpos multivesiculares e lisossomos grandes e claros próximos ao complexo de Golgi. Existe também a intensa marcação pelo anticorpo de toda a camada recémsintetizada de esmalte (principalmente entre os cristais de hidroxiapatita), das invaginações de membrana da região distal das células próximo as microvilosidades e da matriz orgânica presente na superfície lateral dos ameloblastos pré-secretores e secretores. Pouca marcação pode ser observada ao redor de mitocôndrias e do núcleo, podendo ser utilizada como um índice para a marcação inespecífica (CASASCO; CALLIGARO; CASASCO ${ }^{28}$, 1992; INAGE et al. ${ }^{82}$, 1989; NANCI; KAWAGUCHI; KOGAYA ${ }^{118}$, 1994; NANCI, SLAVKIN; $\mathrm{SMITH}^{119}$, 1987; NANCI et al. ${ }^{122}$, 1998). Após o início da fase de maturação, a imunomarcação pode ser encontrada nos grânulos de secreção, retículo endoplasmático rugoso, sáculos do complexo de Golgi e lisossomos. Os grânulos de secreção estão presentes em menor quantidade que na fase de secreção e apenas no início da fase de maturação. A maior marcação 
intracelular pode ser observada dentro dos grânulos de secreção e lisossomos do tipo multivesicular. As análises quantitativas demonstraram que os sáculos do complexo de Golgi e os lisossomos multivesiculares dos ameloblastos em modulação eram geralmente menos reativos que as mesmas organelas dos ameloblastos na fase de secreção. Material amorfo e granular localizado entre as células e nas dobras da borda rugosa da membrana plasmática também demonstram marcação (INAGE et al. ${ }^{81}$, 1996; INAGE et al. ${ }^{82}$, 1989; NANCI; SLAVKIN; SMITH ${ }^{119}$, 1987; NANCI; SLAVKIN; SMITH ${ }^{120}$, 1987; NANCI et al. ${ }^{121}$, 1996; NANCI et al. ${ }^{122}$, 1998). Uma marcação intensa também pode ser observada na camada de esmalte, ao redor do material granular situado nos espaços extracelulares ao longo das bordas laterais ou dentro das invaginações apicais dos ameloblastos de borda rugosa. Eventualmente observam-se marcações dentro ou fora de células da camada papilar, incluindo macrófagos. Apenas pequenos focos de material granular imunorreativo são observados algumas vezes entre as células da camada papilar próximo à base dos ameloblastos (INAGE et al. ${ }^{82}$, 1989; NANCI; SLAVKIN; SMITH ${ }^{119}$, 1987; NANCI; SLAVKIN; SMITH ${ }^{120}$, 1987). Na região final da fase de maturação, quando os prismas são visíveis, as partículas de ouro estão associadas aos cordões de matriz e parecem concentradas na periferia dos prismas. Nesta região, a marcação é menor que quando comparada com o início da fase de maturação. A marcação também ocorre no material elétron-denso acumulado nos espaços próximos à junção amelodentinária, assim como o material orgânico encontrado dentro ou na periferia dos túbulos dentinários (NANCI et al. ${ }^{122}$, 1998).

De forma geral, a marcação na matriz recém-sintetizada de esmalte parece não mostrar diferenças significativas nesse nível de observação na atual pesquisa, mas o que chama a atenção é marcação na pré-dentina, também descrita na literatura por outros pesquisadores (ARANA-CHAVEZ; NANCI ${ }^{10}$, 2001; INAI et al. ${ }^{85}, 1991 ;$ KARG et al. $\left.{ }^{89}, 1997\right)$.

Intensa marcação em dentina foi descrita em ratos por INAGE et al. ${ }^{82}$, 1989 e NANCI et al. ${ }^{122}$, 1998. Nestes trabalhos, respectivamente, foram utilizados ratos machos Wistar com peso aproximado de $40 \mathrm{~g}$ e $100 \mathrm{~g}$. Foi constatada marcação imuno-histoquímica ao redor do material denso ao longo 
do processo odontoblástico e próximo do corpo celular de odontoblastos, na dentina, ao longo da membrana plasmática da região distal e no material encontrado dentro e na periferia de túbulos dentinários de pré-ameloblastos de incisivos de ratos.

No atual trabalho, na fase de secreção mais avançada, o gel de matriz de esmalte mostrou-se bastante homogêneo, sendo essa característica perdida com o avançar do processo de amelogênese. Nos germes de recém-nascidos não pode ser observada a fase de maturação, uma vez que encontram-se no início de sua formação. Nos ratos de 7 e 14 dias de idade a matriz de esmalte em maturação mostrou espaços negativos mais ou menos hexagonais e dispostos como se estivessem empilhados, dirigindo-se desde a superfície apical dos ameloblastos até a região de esmalte aprismático, próxima à junção amelodentinária, onde perdiam parcialmente a conformação descrita, tornandose um pouco desorganizados. Nesta porção de esmalte a marcação para amelogenina foi mais intensa em todos os grupos, tanto nos controle, quanto nos experimentais.

Marcações inespecíficas foram observadas no complexo dentinopulpar, nas fibras colágenas do tecido conjuntivo, em células progenitoras hematopoiéticas da medula óssea e na superfície epitelial da mucosa bucal. Para reduzir esta marcação inespecífica sugere-se aumentar a diluição dos anticorpos primários. Por isso, foi realizada a diluição de 1:3000, como sugerido por $\operatorname{COSTA}^{33}, 2000$, a qual determinou este valor seguindo as normas encontradas no trabalho de DIEKWISCH et al. ${ }^{51}, 1997$, no qual a diluição do anticorpo primário deve ser determinada por vários experimentos preliminares. A diluição do anticorpo primário foi chamada de ótima quando houvesse um forte sinal, mas sem marcações inespecíficas detectadas.

Nos cortes microscópicos usados como controle negativo, onde se omitiu o anticorpo primário, em nenhum momento observou-se qualquer marcação imuno-histoquímica.

Foram poucos os trabalhos que utilizaram técnicas imuno-histoquímicas como método para avaliação das alterações causadas na matriz orgânica de dentes com fluorose. SHORE et al. ${ }^{152}$, 1993, relataram que a marcação para 
amelogenina torna-se mais evidente durante a fase de transição, quando ocorre a degradação da matriz, com o alcance da máxima marcação no final da fase de transição e início da fase de maturação. O efeito do flúor observado por estes autores foi de uma redução na intensidade de marcação da matriz do esmalte até o final da fase de transição, sugerindo que este íon possa reduzir a degradação enzimática, resultando assim numa matriz residual que inibiria o crescimento do cristal, talvez explicando assim a presença dos defeitos de esmalte após a exposição a altos níveis de flúor. É possível que o flúor diminua a marcação imuno-histoquímica por reduzir a degradação enzimática, o que levaria a uma menor exposição dos epítopos.

As alterações ultraestruturais causadas pelo flúor em ameloblastos secretores utilizando técnicas imuno-histoquímicas foram relatadas por MATSUO et al. ${ }^{112}$, 1996. Estes autores utilizaram anticorpos contra amelogenina para avaliar ratos Wistar de oito semanas de vida que receberam injeções subcutâneas de $20 \mathrm{mgF} / \mathrm{kg}$ a partir de uma solução de NaF a 1,25\% durante quatro dias. Nos ameloblastos secretores dos animais tratados com NaF, a marcação era observada em grandes grânulos formados anormalmente, assim como no retículo endoplasmático rugoso, complexo de Golgi e esmalte. A maior marcação era observada em grandes grânulos de baixa densidade contendo conteúdo de granulação fina de elétron-densidade semelhante àquela dos grânulos de secreção. Grandes grânulos de granulação grosseira exibiam marcação fraca ou ausente.

Com a avaliação morfológica subjetiva realizada na atual pesquisa, utilizando imuno-histoquímica, pode-se observar que embora o flúor em altas doses na água de beber alcance os tecidos em filhotes de ratas pela placenta e pelo leite materno, parece pouco capaz de alterar o padrão de marcação imuno-histoquímica das amelogeninas em filhotes com 0, 7 e 14 dias de vida pós-natal. 


\subsection{Considerações sobre os resultados obtidos na análise morfológica em microscopia eletrônica}

Nos exames subjetivos das imagens ultraestruturais da microscopia eletrônica de transmissão (MET), os ameloblastos dos grupos controles (os quais receberam água deionizada sem flúor) apresentaram as mesmas características morfológicas descritas em ratos adultos (RIBEIRO ${ }^{139}, 2001$ ).

$\mathrm{Na}$ maioria dos ameloblastos secretores dos animais experimentais, foi verificada a presença de vacúolos claros na porção apical do citoplasma antes do processo de Tomes, em todas as idades estudadas dos grupos de 100ppm. Estas observações também foram descritas em ratos adultos com dosagens agudas e crônicas de flúor por AOKI $^{9}, 1989$, KRUGER $^{94}, 1968$, OLIVEIRA ${ }^{128}$, 1988, RIBEIRO; ASSIS; HIROTA ${ }^{140}$, 2001 e WALTON; EISENMANN ${ }^{178}$, 1974. Em todas as imagens de MET examinadas, os aspectos morfológicos do núcleo dos ameloblastos foram similares entre os grupos controles e experimentais, mostrando a cromatina e o envoltório nuclear íntegros. O nucléolo também se mostrou com a mesma freqüência e morfologia nos diferentes grupos. Esses dados confirmam que a exposição crônica (RIBEIRO; ASSIS; HIROTA ${ }^{140}$, 2001) ou aguda (KRUGER ${ }^{94}, 1968$ ) de flúor pode promover alterações no citoplasma distal dos ameloblastos, exibindo um padrão semelhante à degeneração hidrópica e outros distúrbios no estádio de secreção (FEJERSKOV et al. ${ }^{63}$, 1980), mas parece não ser capaz de interferir no núcleo celular e, portanto, possivelmente não possa causar interferências no processo de transcrição protéica.

Os ameloblastos secretores observados no grupo experimental de 100ppm nas três idades estudadas mostraram muitas vezes o REG dilatado e desorganizado (com as cisternas nem sempre paralelas). Na idade de 14 dias, foi possível observar inclusive algumas vezes inclusões intracisternais, o que pode ser sugestivo de um não prejuízo da produção protéica. Mas a dilatação das cisternas e a presença de material retido podem sugerir algum distúrbio na via de transporte das proteínas produzidas. Não apenas o REG, mas também os sáculos de Golgi apresentaram-se mais dilatados, como descrito por MATSUO; 
KIYOMIYA; KUREBE ${ }^{111}$, 1998. MATSUO et al. ${ }^{112}, 1996$, já haviam chamado atenção para um maior acúmulo de pequenas vesículas na rota da via secretora entre o REG e o complexo de Golgi, o acúmulo de material intracisternal e a formação anormal de largos grânulos no citoplasma distal. Poder-se-ia deduzir que o flúor interfere no mecanismo de transporte intracelular e exocitose, retardando material protéico dentro das cisternas de REG.

As formações dilatadas do REG sob a ação do flúor já haviam sido descritas por KRUGER ${ }^{94}$, 1968, PATTERSON; BASFORD; KRUGER ${ }^{133}$, 1976 e RIBEIRO; ASSIS; HIROTA ${ }^{140}$, 2001, em ratos adultos.

Vários estudos propõem possibilidades que expliquem as alterações celulares causadas pelo flúor. MATSUO; KIYOMIYA; KUREBE ${ }^{111}$, 1998, estudaram a participação da proteína de ligação guanosina trifosfato (GTP) pequena (proteína $G$ pequena), a qual é uma unidade modular que participa do transporte vesicular e da via secretora. Foi sugerido que esta proteína possa participar no distúrbio do transporte intracelular do ameloblasto secretor exposto ao flúor.

LI et al. ${ }^{103}$, 2005, em um estudo utilizando ameloblastos de camundongo em cultura mostraram que a administração de $\mathrm{NaF}$ numa dosagem de $40 \mathrm{mM}$ causa alteração na quantidade de actina F. Acredita-se que este aumento ocorra devido o flúor inativar a RhoGAP, a qual é uma molécula que regula a produção de uma pequena proteína $\mathrm{G}$ denominada RhoA. Assim, acredita-se que a administração de flúor inative o RhoGAP, permitindo a ativação da RhoA, que leva ao aumento de actina F. Desta forma, o flúor pode alterar o citoesqueleto da célula pela interferência da via de sinalização Rho, o que pode causar uma interferência não apenas na via secretora, mas também na via de reabsorção das proteínas.

KUBOTA et al. ${ }^{98}$, 2005, realizaram um estudo em ameloblastos de camundongos cultivados in vitro expostos a diferentes concentrações de $\mathrm{NaF}$ que variaram de 0 e $2 \mathrm{mM}$. Nesta pesquisa, os autores sugeriram que a exposição a altos níveis de flúor possa inibir a síntese protéica por indução de agentes, como a proteína Ire1, que possam causar estresse no retículo endoplasmático, alterando o processo de síntese celular e retenção das 
proteínas. Isto favoreceria a ativação de caspases as quais atuam no DNA provocando danos que podem levar a apoptose. Apesar desta hipótese ser levantada por estes autores, nas lâminas e imagens do MET examinadas na atual pesquisa não foi possível encontrar corpos apoptóticos ou núcleos celulares que pudessem estar sofrendo um processo apoptótico. Talvez uma amostragem maior ou uma metodologia específica como uma reação imunohistoquímica pudessem comprovar essa hipótese.

As mitocôndrias observadas nos ameloblastos secretores estavam principalmente localizadas na porção basal, ocupando todo o citoplasma subnuclear. Algumas nos grupos experimentais muitas vezes davam a impressão de estar mais dilatadas que as observadas nos grupos controles, mostrando espaços claros maiores entre as cristas mitocondriais. Estas observações foram semelhantes às mencionadas por KRUGER ${ }^{94}$, 1968, PERGOLIZZI et al. ${ }^{134}$, 1995 e RIBEIRO; ASSIS; HIROTA ${ }^{140}$, 2001, em animais adultos.

Muitos estudos ultraestruturais focaram ameloblastos secretores. Mas poucos são os trabalhos em ameloblastos na fase de maturação em condições experimentais de fluorose. Um dos poucos trabalhos foi desenvolvido por RIBEIRO $^{139}$, 2001, em um estudo estereológico utilizando ratos adultos. Nesta pesquisa, o autor observou redução da quantidade de REG e mitocôndrias e um aumento de os vacúolos digestivos de menor diâmetro.

No atual trabalho, foi observado uma grande quantidade de produtos de endocitose eletrondensos na região apical próxima à matriz do esmalte em ameloblastos em maturação de borda lisa nas idades de 7 e 14 dias do grupo de 100ppm de flúor. Esse material endocitado parece ser semelhante ao descrito por RIBEIRO ${ }^{139}, 2001$.

$\mathrm{AOKI}^{9}$, 1989, também descreveu em ratos submetidos a condições de fluorose a presença de vacúolos mais densos na região apical dos ameloblastos de borda lisa. Na transição dos ameloblastos secretores para maturação, foi verificado que os vacúolos claros presentes no ameloblasto secretor ainda permanecem algum tempo no período de transição, prejudicando o início da reabsorção da matriz. 
Nos ameloblastos de borda rugosa a única alteração morfológica subjetiva verificada foi a presença de mitocôndrias dilatadas entre as invaginações do plasmalema apical. $O$ dano em mitocôndrias também foi descrito por PERGOLIZZI et al. ${ }^{134}$, 1995, o qual ainda demonstrou a diminuição da quantidade de ameloblastos de borda em escova (rugosa) em incisivo de ratos adultos expostos a dosagens crônicas de flúor em água de beber.

\subsection{Considerações sobre os resultados morfométricos da matriz de esmalte}

Acredita-se que o esmalte formado na presença de flúor apresenta uma maior abundância de proteínas de baixo peso molecular na fase de secreção e uma menor redução de proteínas de alto peso molecular durante a fase de maturação. Desta forma, o flúor talvez possa atuar reduzindo ou prevenindo a quebra de proteínas de alto peso molecular em unidades menores, podendo induzir alterações molecular ou estrutural nas proteínas, tornando-as menos sujeitas à degradação. Assim, o flúor pode apresentar efeitos sobre as amelogeninas, enamelinas ou em ambas proteínas, alterando a composição bioquímica da matriz de esmalte. Desta forma, os efeitos do flúor sobre o esmalte parecem iniciar durante a fase de secreção da amelogênese (BASFORD; PATTERSON; KRUGER ${ }^{14}$, 1976; DENBESTEN; CRENSHAW ${ }^{44}$, 1984; DRINKARD; CRENSHAW; BAWDEN ${ }^{53}$, 1983; PATTERSON; BASFORD; KRUGER ${ }^{133}$, 1976; ROBINSON et al. ${ }^{145}$, 1979).

Uma grande dificuldade na realização desta etapa do projeto foi a obtenção e seleção de material adequado para análise. Embora vários cortes representassem uma fatia exata no longo eixo do incisivo e no maior comprimento, a maioria deles não preenchia os requisitos necessários para a sua utilização.

Para a seleção dos cortes foram utilizados alguns critérios. Primeiramente, o corte deveria ter sido realizado o mais próximo do longo eixo do dente, evitando cortes em posição oblíqua ou inclinada, o que poderia 
impossibilitar a avaliação de toda a matriz ou mesmo aumentar a área da mesma.

Sabe-se que o incisivo de rato não apresenta uma disposição retilínea, mas sim uma curvatura considerada como um pequeno segmento de uma espiral de 140 a $150^{\circ}$ (SCHOUR; MASSLER ${ }^{150}$, 1949). Além disso, nos animais recém-nascidos e jovens, o seu pequeno tamanho e pouca espessura dificultaram em muito a obtenção de cortes numa posição correta para a análise.

Foram desprezados os cortes onde a alça cervical não era visualizada, uma vez que poderia sugerir um corte fora da região central ao longo eixo do dente. Os cortes também foram descartados quando os ameloblastos apresentavam-se cortados obliquamente, pois, além de representarem um corte inadequado do incisivo, também dificultariam a avaliação do final da fase de secreção. Qualquer outro corte onde se percebesse uma secção não realizada próxima à região central do seu longo eixo, teve que ser desprezada. Além disso, para a análise as amostras deveriam apresentar a matriz de esmalte preservada ao máximo em toda sua extensão. Os cortes onde a porção final da matriz tivesse sido perdida ou deslocada da sua posição original foram desprezados. Todos estes critérios reduziram em muito o material disponível para análise.

Devido ao fato de existir pouco material adequado para a análise, optouse por utilizar lâminas de diferentes colorações. Este material, utilizado anteriormente para análise morfológica, foi corado pelas técnicas de Hematoxilina e Eosina (H.E.) e imuno-histoquímica.

Em relação a animais recém-nascidos e no período pós-natal inicial do desenvolvimento, não existem estudos que avaliaram o comprimento da matriz do esmalte. $\mathrm{Na}$ atual pesquisa, não foram observadas diferenças significantes no comprimento da matriz na fase de secreção dos subgrupos de zero dias. Este fato sugere que o flúor administrado em mães durante o período da gestação, embora chegue aos fetos por via placentária, parece não afetar a síntese e secreção da matriz de esmalte nesta idade. 
Na fase de secreção, aos sete dias de vida pós-natal, também não houve diferença estatística entre as medidas de comprimento da matriz de animais cujas mães receberam 0 e $7 \mathrm{ppm}$ de flúor. Isto pode sugerir que o flúor na concentração de $7 \mathrm{ppm}$ administrado para a mãe não cause toxicidade aos filhotes nesta idade, os quais recebem parte destes íons por via do leite materno. Entretanto, em relação ao grupo de $100 \mathrm{ppm}$ nota-se uma redução de $14,38 \%$ no comprimento da matriz na fase de secreção, quando comparado ao grupo controle. Isto pode sugerir que o flúor recebido no leite materno possa reduzir a produção de esmalte, antecipando assim a maturação do esmalte nesta idade. Em relação à fase após secreção, a qual incluía os períodos de transição e maturação do esmalte não foram observadas diferenças estatísticas em nenhum dos subgrupos analisados. Em relação ao comprimento total da matriz, notou-se uma redução significativa de $5,78 \%$ no comprimento da matriz de animais cujas mães receberam 100ppm.

Aos 14 dias de vida pós-natal, o comprimento da matriz na fase de secreção no grupo de $7 \mathrm{ppm}$ foi $16,47 \%$ maior que o grupo de zero ppm com significância estatística. Na fase de maturação, não foram observadas diferenças estatísticas entre nenhum dos subgrupos estudados. Em relação ao comprimento total da matriz, houve um aumento significativo de $12,91 \%$ no comprimento da matriz de animais do grupo de $7 \mathrm{ppm}$, quando comparado ao grupo controle.

Segundo MACIEJEWSKA; ADAMOVICZ-KLEPALSKA ${ }^{108}$, 2000 e MACIEJEWSKA et al. ${ }^{109}, 2000$, o flúor em baixas doses acelera 0 desenvolvimento do germe dentário. Um aumento no comprimento dentário por ação do flúor foi descrito por GLENN; GLENN; BURDI $^{76}$, 1997, utilizando hamsters prenhes de três dias que receberam 0, 10 e 20ppm de flúor na água de beber. Os filhotes dessas mães foram sacrificados ao nascimento, sendo os incisivos inferiores utilizados para medida de comprimento dentário. Foram observados valores de comprimento dentário de 1,95, 2,11 e 2,26mm, respectivamente para os grupos de 0,10 e 20ppm de flúor, todos apresentando diferenças estatísticas entre si. Os autores inclusive sugeriram que o flúor possa 
servir de nutriente essencial para o desenvolvimento dentário, sendo importante a administração do íon durante a formação de dentes decíduos.

Entretanto, de qualquer forma, ainda é precoce afirmar que uma dosagem ideal de flúor possa favorecer o desenvolvimento dentário ou aumentar a retenção da matriz de esmalte.

Em relação aos animais adultos, os resultados obtidos em animais jovens diferem-se em alguns parâmetros. No trabalho realizado por $\operatorname{COSTA}^{33}, 2000$, foram utilizados 15 ratos Wistar, divididos em três grupos tratados com 0,7 ou 100ppm de flúor em água de beber ad libitum durante 42 dias. Foram utilizados cortes histológicos dos incisivos inferiores que sofreram a mesma reação imuno-histoquímica utilizada na atual pesquisa. Os resultados para comprimento total de matriz foram de 6,79, 6,25 e 9,94mm, respectivamente para os animais que receberam 0, 7 e 100ppm de flúor. Para o comprimento da matriz na fase de maturação foram obtidos valores de 1,81, 2,06 e 5,32mm, respectivamente para os mesmos grupos. Para ambas medições, houve diferença estatística significante apenas nos animais que receberam $100 \mathrm{ppm}$. Isto sugere que ocorra uma retenção de 2,94 vezes, ou seja, quase 300\% maior da matriz na fase de maturação em animais que receberam 100ppm flúor quando comparados com o grupo controle. Fazendo-se o cálculo para a fase de secreção, a autora sugere não haver influência do flúor sobre a quantidade linear de matriz produzida e secretada. Nesta mesma pesquisa, embora não tenha sido mensurado o comprimento da coroa clínica dos incisivos, foi sugerido que os animais que receberam 100ppm apresentavam incisivos inferiores mais curtos que os demais, sugerindo um atraso em sua formação. Por outro lado, a compatibilidade dos valores obtidos em animais que receberam 0 e 7ppm de flúor pode ser considerada como um indicador da falta de toxicidade do flúor na concentrações adotada no segundo grupo.

A retenção e o conseqüente aumento no comprimento da matriz de esmalte foram detectados também em um estudo de SMITH; NANCI; DENBESTEN ${ }^{164}, 1993$, utilizando incisivos inferiores de ratas Sprague-Dawley com peso corporal aproximando de $250 \mathrm{~g}$, as quais receberam $100 \mathrm{ppm}$ de flúor na água de beber durante seis semanas. Foi observado um aumento no 
comprimento sagital dos dentes cujos animais receberam flúor, sendo obtidos valores de comprimento do esmalte parcialmente solúvel em EDTA de 3480 e $3112 \mu \mathrm{m}$, respectivamente para animais que receberam 100ppm e o grupo controle. E valores de comprimento de esmalte totalmente solúvel em EDTA de 5592 e $4607 \mu \mathrm{m}$, respectivamente para os mesmos grupos. Foi observado também que o tratamento crônico de flúor na água induz a produção de uma camada mais fina de esmalte, sendo observados valores de espessura de esmalte entre as fases de secreção e maturação de 105 e 115 $\mu$ m, respectivamente para os animais expostos e não expostos ao flúor.

ZHOU; ZAKI; EISENMANN ${ }^{185}$, 1996, também observaram a retenção da matriz numa pesquisa utilizando ratas Sprague-Dawley de peso corporal de 30$35 \mathrm{~g}$ as quais consumiram água contendo 0, 75 ou 100ppm de flúor na água de beber durante seis semanas. Respectivamente, nestes grupos foram observados valores de comprimento de matriz de esmalte de 5,561, 7,1441 e 7,4334mm; sem diferenças estatísticas entre os grupos que receberam flúor. Para os respectivos grupos, os valores de espessura da matriz de esmalte no início da fase de maturação foi de 0,10311, 0,08459 e 0,09340mm, apresentando diferenças estatísticas entre todos os grupos. Estes resultados assemelham-se aos obtidos por SMITH; NANCI; DENBESTEN ${ }^{164}$, 1993, onde ocorre uma maior retenção da matriz e menor espessura do esmalte.

Entretanto, os resultados em relação ao comprimento da matriz de esmalte são controversos. FEJERSKOV et al. ${ }^{63}$, 1980, realizaram um estudo em ratos de 30 e 90 dias de vida pós-natal os quais receberam 0, 56,5 e 113ppm de flúor na água de beber. Neste trabalho, foi verificado que o comprimento da matriz na fase de maturação era em média $25 \%$ menor nos animais expostos ao flúor quando comparado com o grupo controle.

\subsection{Considerações sobre os resultados morfométricos para ameloblastos}

Os ameloblastos secretores são células altamente polarizadas, organizadas em um epitélio prismático simples alto (SASAKI; TAKAGI; YANAGISAWA $^{148}$, 1997). No atual trabalho, foi verificado em analisador de 
imagem que estas células atingem uma altura média de $63,35 \mu \mathrm{m}$ no dia de nascimento, aumentando para 69,50 $\mu \mathrm{m}$ aos sete dias de vida pós-natal e alcançando um valor de $72,63 \mu \mathrm{m}$ no $14^{\circ}$ dia. Estes valores encontram-se próximos aos observados na literatura.

Em incisivos superiores de ratos adultos, REITH ${ }^{138}$, 1961, verificou que estas células medem aproximadamente $60 \mu \mathrm{m}$ ou mais em altura, mas apenas 2 a $3 \mu \mathrm{m}$ de largura. Um valor máximo para altura foi determinado por SMITH; NANCI ${ }^{163}, 1989$, os quais verificaram que, em incisivos inferiores de ratos machos Wistar com peso aproximado de $100 \mathrm{~g}$, os ameloblastos secretores

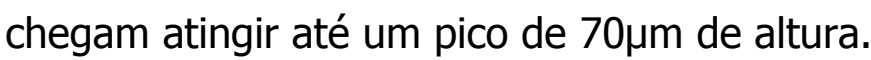

Valores semelhantes foram encontrados por ROBINSON; BRIGGS; ATKINSON $^{143}$, 1981. Estes autores também consideraram que a altura média dos ameloblastos secretores varia entre 60-70 $\mu \mathrm{m}$ em incisivos inferiores de ratos machos Wistar pesando 200-250g. Resultados semelhantes a estes foram também verificados em incisivos superiores de ratos albinos por PINDBORG; WEINMANN ${ }^{135}$, 1959. Estes pesquisadores encontraram um valor médio para altura celular de ameloblastos secretores de $70 \mu \mathrm{m}$.

Vale ressaltar que, uma dificuldade verificada a análise morfométrica da altura celular está no fato que o ameloblasto apresenta alturas diferentes de acordo com a sua localização em relação à sua posição na coroa dentária e o momento em que se encontra durante o processo de amelogênese, podendo aumentar ou até mesmo diminuir na mesma fase da formação do esmalte. Ou seja, pode haver uma variação no comprimento da célula durante a fase de secreção e também na fase de maturação.

Isto pode ser observado, por exemplo, no estudo de LANGE; HAMMARSTRÖM $^{99}, 1984$, os quais estudaram primeiros molares superiores de ratos Sprague-Dawley de 2 a 12 dias de vida pós-natal. Nesta pesquisa, os autores verificaram que o valor máximo para altura de ameloblastos secretores foi de $109 \mu \mathrm{m}$ no lado mesial da cúspide medial aos quatro dias de vida. O valor

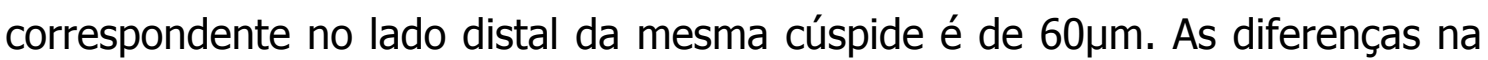
altura das células dos lados mesial e distal foram observadas nas cúspides mesial, medial e distal estudadas. 
Não foram encontrados trabalhos na literatura que tenham observado a influência do flúor na altura celular de ameloblastos secretores de animais recém-nascidos, jovens ou adultos. Embora pareça haver uma redução na altura celular quanto maior é a dosagem de flúor, não houve diferenças estatísticas na altura celular em nenhum dos subgrupos estudados. Desta forma, o flúor parece não interferir de forma significativa na altura celular em nenhuma das dosagens administradas e em nenhum dos grupos etários.

No período de transição entre a fase de secreção e a de maturação, ocorrem uma redução na altura dos ameloblastos e uma modificação no tipo de organelas citoplasmáticas predominantes. Neste período, também ocorre a remoção do excesso de organelas associadas à síntese, as quais são acondicionadas em vacúolos autofágicos e digeridas por enzimas lisossômicas. Dentro destes vacúolos encontram-se cisternas de retículo endoplasmático rugoso, polirribossomas, mitocôndrias, estruturas filamentosas e numerosos grânulos (SALAMA; ZAKI; EISENMANN ${ }^{146}$, 1991; TEN CATE ${ }^{172}$, 2001).

$\mathrm{Na}$ fase de transição, em incisivos inferiores de ratos adultos, podem ser facilmente observados ameloblastos altos $(60-70 \mu \mathrm{m})$, outros sofrendo redução de altura e outros baixos (40-50 $\mu \mathrm{m})$. Ao microscópio de luz, a redução brusca na altura celular pode ser facilmente verificada (KALLENBACH ${ }^{88}$, 1974; SILVASOUSA et al. ${ }^{153}$, 2003).

$\mathrm{Na}$ atual pesquisa, os ameloblastos da fase de maturação apresentaram uma altura de $45,50 \mu \mathrm{m}$ aos sete dias e $42,07 \mu \mathrm{m}$ aos 14 dias de vida pós-natal. JOSEPHEN; FEJERSKOV ${ }^{87}$, 1977, observaram que ameloblastos de incisivos superiores de ratas fêmeas com 91 dias de vida apresentam altura variando de 40 a $60 \mu \mathrm{m}$ e largura aproximada de $5 \mu \mathrm{m}$. Entretanto, segundo SMITH; NANCI ${ }^{162}, 1989$, os quais utilizaram como modelo os incisivos inferiores de ratos machos Wistar com peso aproximado de $100 \mathrm{~g}$, os ameloblastos na fase de maturação possuem cerca de $40 \mu \mathrm{m}$ de altura, um valor correspondente ao mínimo observado por JOSEPHSEN; FEJERSKOV ${ }^{87}$, 1977. Resultados semelhantes a estes foram também verificados em incisivos superiores de ratos albinos por PINDBORG; WEINMANN ${ }^{135}$, 1959. Estes pesquisadores encontraram um valor médio para altura celular de ameloblastos na fase de maturação de 
aproximadamente $40 \mu \mathrm{m}$. Valores menores na altura celular foram encontrados em incisivos superiores de ratos adultos por REITH ${ }^{138}, 1961$, o qual verificou em sua amostra que estas células medem aproximadamente $35 \mu \mathrm{m}$ de altura.

Em relação ao tipo de ameloblasto na fase de maturação, SASAKI ${ }^{147}$, 1984, verificou, em germes de primeiros e segundo molares de gatos com quatro meses de vida, que tanto as células de terminação rugosa quanto as de borda lisa apresentam uma altura de aproximadamente 30 a $40 \mu \mathrm{m}$. SASAKI et al. ${ }^{149}, 1983$, em incisivos inferiores de ratos Sprague-Dawley de 3 a 5 semanas de vida pós-natal, observaram uma altura média de 30 a $35 \mu \mathrm{m}$ em ameloblastos de borda lisa na fase de maturação.

Existem poucos trabalhos na literatura que tenham observado a influência do flúor na altura celular de ameloblastos na fase de maturação de animais recém-nascidos, jovens ou adultos. RIBEIRO ${ }^{139}$, 2001, utilizou incisivos inferiores de ratas Wistar de 30 dias de vida pós-natal com peso aproximado de $100 \mathrm{~g}$, as quais receberam 0, 7 e 100ppm de flúor na água de beber durante seis semanas. Nestas amostras foram determinados os mesmos cálculos morfométricos estudados na atual pesquisa. A altura do ameloblasto na fase de maturação dos grupos controle e experimentais de 7 e 100ppm foi, respectivamente, de 48,14 $\pm 3,69,42,16 \pm 4,36$ e 35,32 $\pm 3,66 \mu \mathrm{m}$, havendo uma redução estatisticamente significante de $27 \%$ no grupo de 100 ppm em relação ao grupo controle. Vale lembrar que estes cálculos foram realizados aleatoriamente, sem distinções em ameloblastos de borda lisa e rugosa.

A redução na altura do ameloblasto também foi detectada em um estudo de SMITH; NANCI; DENBESTEN ${ }^{164}$, 1993, utilizando incisivos inferiores de ratas Sprague-Dawley com peso corporal aproximando de $250 \mathrm{~g}$, as quais receberam 100ppm de flúor na água de beber durante seis semanas. Embora o trabalho demonstre por figuras a diferença estatística observada na altura de ameloblastos na fase de maturação dos grupos experimental e controle, os autores não descreveram em termos percentuais os valores encontrados para 0 decréscimo em altura. A redução na altura celular foi descrita tanto para ameloblastos de borda rugosa quanto para os de borda lisa. Foi observada também uma redução na altura da camada papilar. 
Embora os resultados obtidos na atual pesquisa sugiram haver uma redução na altura celular quanto maior é a dosagem de flúor, não houve diferenças estatísticas na altura celular em nenhum dos subgrupos estudados na fase de maturação.

No atual trabalho, foi observada uma redução no volume citoplasmático em ameloblastos secretores. No grupo de sete dias, o volume citoplasmático do ameloblasto secretor do subgrupo de 100 dias foi $23,80 \%$ e $17,63 \%$ menor que os valores observados para os subgrupos de zero e $7 \mathrm{ppm}$ de flúor. No grupo de 14 dias, o volume citoplasmático do ameloblasto secretor do grupo de 100 dias foi $24,75 \%$ e $16,09 \%$ menor que os valores observados nos subgrupos de zero e 7 ppm de flúor. Uma vez que o flúor não interferiu na altura das ameloblastoss, dentro da mesma idade, parece possível que tenha existido uma redução na largura dos ameloblastos secretores da atual pesquisa.

Entretanto, estas alterações morfológicas em ameloblastos secretores não foram observadas por RIBEIRO; ASSIS; HIROTA ${ }^{140}$, 2001, estudando incisivos de ratos adultos que receberam 0 ou 100 ppm de flúor na água de beber ad libitum. Nesta pesquisa, também não foram observadas diferenças estatísticas na densidade de volume e volume absoluto do núcleo e citoplasma entre os grupos.

$\mathrm{Na}$ fase de maturação, o volume do núcleo e do citoplasma dos ameloblastos não mostraram diferenças estatisticamente significantes em função do tratamento com o flúor em nenhuma das idades estudadas.

RIBEIRO $^{139}$, 2001, observou, em ameloblastos na fase de maturação de incisivos de ratos adultos, valores de volume absoluto citoplasmático de $2244,48 \pm 315,51,1864,18 \pm 316,88$ e $1538,13 \pm 346,58 \mu m^{3}$, respectivamente para os mesmos grupos. Apenas o volume citoplasmático do grupo de $100 \mathrm{ppm}$ foi $31 \%$ menor $(p<0,05)$ que o grupo controle. Esta redução no volume absoluto do citoplasma foi atribuída à diminuição da altura do ameloblasto, uma vez que as densidades de volume do núcleo e do citoplasma, e a relação núcleo/citoplasma não mostraram diferenças estatisticamente significantes.

Como vimos na atual pesquisa, as alterações morfométricas foram mais significativas na fase de secreção que na de maturação. Outros estudos 
também demonstraram que, embora os efeitos do flúor sejam mais evidentes na fase de maturação do esmalte, a concentração do mesmo é maior na matriz do esmalte parcialmente mineralizado do que nos estádios mais avançados da mineralização (OLIVEIRA ${ }^{128}$, 1988; SPEIRS ${ }^{167}$, 1975; SPEIRS $^{168}$, 1978; WEATHERELL et al. $\left.{ }^{180}, 1975\right)$.

A maior concentração de flúor no interior do esmalte durante a amelogênese é observada no início da fase de maturação (KATO et al. ${ }^{90}, 1988$ ). Assim, no momento ou logo antes dessa fase, quando o esmalte começa a mineralizar rapidamente, as concentrações de flúor são particularmente altas. A concentração cai rapidamente à medida que o conteúdo mineral do tecido atinge aquela do esmalte maduro (WEATHERELL et al. ${ }^{180}$, 1975).

Existem várias hipóteses que tentam explicar porque o flúor tem maior ação sobre o esmalte no início da fase de maturação. Uma delas é que o flúor provavelmente possa estar ligado seletivamente às proteínas do esmalte jovem (CRENSHAW; WENNBERG; BAWDEN ${ }^{35}$, 1978). Outra hipótese sugere que o flúor, possivelmente adquirido na forma iônica quando o esmalte está parcialmente mineralizado, seja diluído durante a deposição subseqüente de esmalte relativamente livre de flúor. Outra possibilidade seria que o flúor adquirido nas fases iniciais da amelogênese fosse perdido durante a mineralização do tecido (WEATHERELL et al. ${ }^{180}$, 1975). Ou ainda, a susceptibilidade aos efeitos negativos do flúor no início do estádio de maturação parece estar associada à inibição da proteólise na matriz, resultando no acúmulo de material orgânico. Especialmente as amelogeninas parecem sofrer maior retenção durante o início da fase de maturação. Mesmo não se conhecendo com exatidão a função das amelogeninas na mineralização do esmalte, acredita-se que as mesmas controlam a orientação do crescimento dos cristais em extensão. A administração de flúor, durante a fase secretora da amelogênese, inibe tal crescimento, indicando que o flúor rompe temporariamente 0 controle das amelogeninas sobre a mineralização (DENBESTEN; CRENSHAW ${ }^{45}$, 1987). 
152

Discussão 
Conclusões

154 


\section{Conclusões}

Baseado nos resultados obtidos pode-se constatar que a dosagem de 7ppm não provocou alterações morfológicas significativas, exceto no grupo de 14 dias onde foi observado um maior comprimento da matriz de esmalte. 0 excesso de flúor na dosagem de 100ppm provocou em germes dos incisivos de ratos recém-nascidos e com sete e 14 dias de vida pós-natal:

\section{Na matriz do esmalte examinada no microscópio óptico:}

- um padrão de identificação imuno-histoquímico da amelogenina homogêneo e pouco intenso na matriz do esmalte, mas intenso na pré-dentina, semelhante ao grupo controle;

- um menor comprimento de matriz de esmalte retida.

\section{Nos ameloblastos secretores:}

- o aparecimento de grandes vacúolos na região apical do citoplasma;

- o aparecimento de algumas regiões de retículo endoplasmático rugoso mais dilatadas, com as cisternas mais desorganizadas e material intracisternal retido e com poucas alterações no complexo de Golgi ou nos grânulos de secreção;

- dilatações das mitocôndrias, mostrando as cristas mais desorganizadas;

- uma redução no volume citoplasmático apenas nos animais de 7 e 14 dias.

\section{Nos ameloblastos em maturação:}

- de borda lisa: o aparecimento de grande quantidade de vacúolos com matriz eletrondensa endocitada, sugerindo retardo na reabsorção;

- de borda rugosa: a presença de algumas mitocôndrias dilatadas.

Portanto, de acordo com o protocolo deste estudo, o fluoreto de sódio oferecido em excesso à ratos durante a prenhez em água de consumo passa pela placenta e pelo leite e não altera a produção das amelogeninas dos incisivos dos filhotes, interferindo na secreção e reabsorção da matriz. 
Conclusões

156 


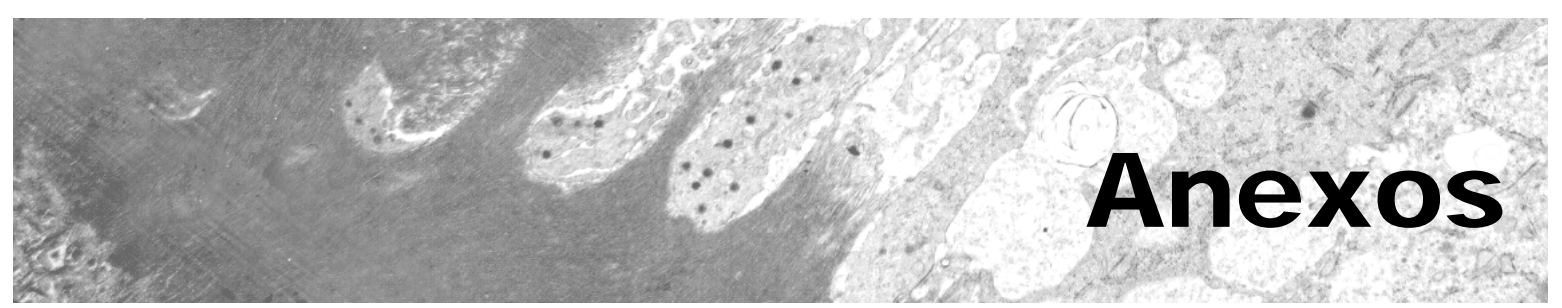


ANEXO 1 - Protocolo para preparo da solução fixadora de paraformaldeído

\section{Preparo da solução A}

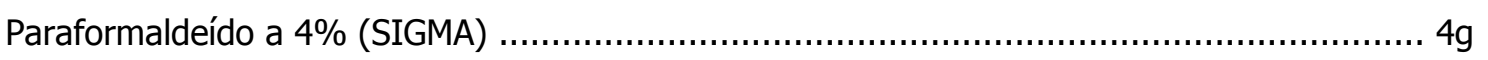

Solução de fosfato de sódio $\left(\mathrm{Na}_{3} \mathrm{PO}_{4}\right)($ MERCK) ................................................. 100ml

Preparo da solução de paraformaldeído a $4 \%$ e aldeído glutárico a $1 \%$

Glutaraldeído a $70 \%$ (SIGMA) …................................................................

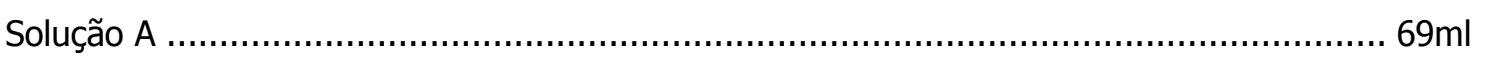

ANEXO 2 - Protocolo para preparo da solução de EDTA

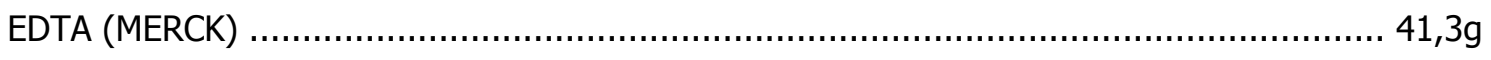

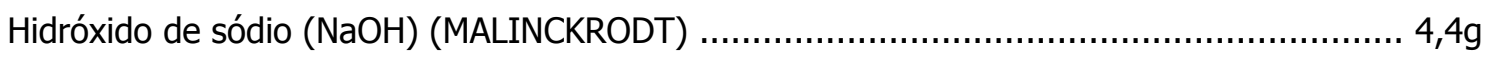

Água destilada ................................................................................ $1000 \mathrm{ml}$ 
ANEXO 3 - Protocolo para preparo dos corantes utilizados na técnica de Hematoxilina e Eosina (H.E.)

\section{HEMATOXI LI NA DE HARRIS}

\section{Solução A}

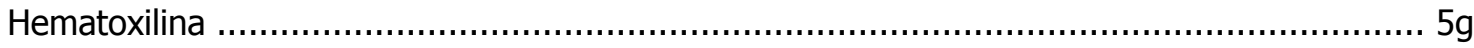

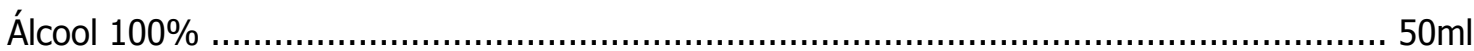

\section{Solução B}

Alúmen de potássio $100 \mathrm{~g}$

Água destilada quente $1000 \mathrm{ml}$

\section{Preparo}

Juntar as soluções A e B e depois adicionar $2,5 \mathrm{~g}$ de óxido de mercúrio vermelho. Ferver e depois esfriar rapidamente

\section{EOSINA DE LISON}

\section{Solução A}

Eosina

Álcool $100 \%$

$100 \mathrm{ml}$

\section{Solução B}

Bicromato de potássio $5 \mathrm{~g}$

Água destilada $800 \mathrm{ml}$

\section{Solução saturada de ácido pícrico}

Ácido pícrico $1,22 \mathrm{~g}$

Água destilada $100 \mathrm{ml}$

\section{Preparo}

Juntar as soluções A e B e depois adicionar a solução saturada de ácido pícrico 


\section{ANEXO 4 - Protocolo para preparo da coloração de Hematoxilina e Eosina}

\section{Desparafinização}

- Dois banhos em xilol (1) por 15 minutos

- Um banho em xilol (2) por 15 minutos

\section{Hidratação}

- Dois banhos em álcool absoluto (1) por cinco minutos

- Um banho em álcool absoluto (2) por cinco minutos

- Um banho em álcool 70 por cinco minutos

\section{Lavagem}

- Lavagem em água corrente por dez minutos, sendo cinco trocas rápidas de água e mais cinco trocas a cada dois minutos

\section{Coloração}

- Um banho em Hematoxilina de Harris por um minuto

- Lavagem em água corrente, sendo várias trocas rápidas até água perder o corante e um banho até completar dez minutos

- Um banho em Eosina e Lison por dois minutos

- Lavagem rápida em água corrente

\section{Desidratação}

- Um banho rápido em álcool 70\%

- Dois banhos rápidos em álcool absoluto (1)

- Um banho de álcool absoluto (2) por três minutos

- Um banho de álcool absoluto (3) por três minutos

- Um banho de álcool absoluto (4 - produto novo) por três minutos

\section{Diafanização}

- Um banho de xilol (1) por três minutos

- Um banho de xilol (2) por três minutos

- Um banho de xilol (3) por três minutos

\section{Montagem da Lâmina}

- Montagem da lâmina com resina ENTELLAN (Merck, Alemanha) 
ANEXO 5 - Protocolo para o tratamento imuno-histoquímico da amelogenina

\section{Desparafinização, Reidratação e Lavagem}

- Desparafinização em estufa a $63^{\circ} \mathrm{C}$ por 30 minutos

- Desparafinização em xilol com três banhos de dez minutos

- Reidratação em álcool etílico absoluto com um banho de dez minutos e um de cinco minutos

- Reidratação em álcool etílico a 95\% com um banho de cinco minutos

- Reidratação em álcool etílico a $80 \%$ com um banho de cinco minutos

- Lavagem em água destilada com dois banhos de cinco minutos

- Secagem do excesso ao redor do corte com gaze ou papel de filtro

\section{I nibição da Peroxidase Endógena}

- Inibição da peroxidase endógena com gotejamento de peróxido de hidrogênio a 3\% (DAKO ${ }^{\circledR}$ Peroxidase Blocking Reagent Code no. S2001) por 15 a 25 minutos

- Lavagem em PBS com pipeta P1000 (Pipeta Pipetman - precision microliter pipette - GILSON)

- Lavagem em PBS com dois banhos de dez minutos

- Secagem do excesso ao redor do corte com gaze ou papel de filtro

\section{Exposição dos Epítopos}

- Exposição dos epítopos com proteinase $\mathrm{K}$ (30 $\mu \mathrm{l}$ de proteinase $\mathrm{K}$ diluídos em 7,5ml de PBS) por uma hora

- Lavagem em PBS com pipeta P1000 (Pipeta Pipetman - precision microliter pipette - GILSON)

- Lavagem em PBS com três banhos de cinco minutos

- Secagem do excesso ao redor do corte com gaze ou papel de filtro

\section{Bloqueio das proteínas do sangue}

- Gotejamento do bloqueador das proteínas do sangue (Dako X0909 - soro eqüino normal a 2\% em PBS) por uma hora para evitar o "background";

- Lavagem em PBS com pipeta P1000 (Pipeta Pipetman - precision microliter pipette - GILSON)

- Lavagem em PBS com dois banhos de PBS por cinco minutos

- Secagem do excesso ao redor do corte com gaze ou papel de filtro

\section{Exposição ao anticorpo primário}

- Incubação dos cortes no respectivo anticorpo primário previamente diluído (1:3000, utilizando pipeta P10 marcando 010 (1 $\mu \mathrm{l})$ do anticorpo primário previamente descongelado) em $3 \mathrm{ml}$ de 
PBS pH 7,4 contendo BSA (albumina sorológica bovina) a 1\% por dez horas em câmara úmida. Separa-se uma ou mais lâmina do grupo que não receberá o anticorpo primário para ser utilizada como controle. Esta lâmina permanece com PBS durante o tempo de exposição ao anticorpo primário.

- Lavagem em PBS com pipeta P1000 (Pipeta Pipetman - precision microliter pipette - GILSON)

- Lavagem em PBS com três banhos de cinco minutos

- Secagem do excesso ao redor do corte com gaze ou papel de filtro

\section{Exposição ao anticorpo secundário conjugado com biotina}

- Tratamento dos cortes no anticorpo secundário conjugado com biotina (imunoglobulinas eqüinas anti-coelho e anti-camundongo biotinilada - Dako $\operatorname{LSAB}^{\circledR} 2$ system - universal para rato

- Kit-Link-biotinylate anti-mouse Ig / biotinilated anti-rabbit Ig Item no. 002525) diluído em 1:400 em PBS ou kit ABC (seguindo as instruções do fabricante) por 30 minutos

- Lavagem em PBS com pipeta P1000 (Pipeta Pipetman - precision microliter pipette - GILSON)

- Lavagem em PBS com três banhos de cinco minutos

- Secagem do excesso ao redor do corte com gaze ou papel de filtro

\section{Tratamento com enzima avidina-biotina}

- Tratamento com a enzima avidina-biotina (Dako LSAB $^{\circledR} 2$ system - universal para rato Streptavidin - HPR - Streptavidin peroxidase conjugated Item no. 002527) diluída em 1:400 em PBS ou kit ABC (seguindo as instruções do fabricante) por 30 minutos

- Lavagem em PBS com pipeta P1000 (Pipeta Pipetman - precision microliter pipette - GILSON)

- Lavagem em PBS com três banhos de cinco minutos

- Secagem do excesso ao redor do corte com gaze ou papel de filtro

\section{Aplicação da diaminobenzidina}

- Incubação em solução de uma gota de diaminobenzidina (DAB) (DAKO Liquid DAB Chromogen $\sim$ Code no. 003222) diluída em 1ml de solvente (Buffered substrate for liquid DAB Item no. 002897) do KIT DAKO Liquid DAB substrate - chromogen system Code no. K3466 por 25 segundos

- Lavagem em água destilada com pipeta P1000 (Pipeta Pipetman - precision microliter pipette

- GILSON)

- Lavagem em água destilada com dois banhos de dez minutos

\section{Contra-coloração}

- Contra-coloração com Hematoxilina de Harris por dois a três minutos

- Lavagem em água destilada por cinco minutos 


\section{Desidratação, Diafanização e Montagem da Lâmina}

- Desidratação em álcool a 80\% por cinco minutos

- Desidratação em álcool a 95\% por cinco minutos

- Desidratação em álcool a 100\% por cinco minutos

- Diafanização em xilol com três banhos de cinco minutos

- Montagem da lâmina com resina ENTELLAN (Merck, Alemanha)

\section{Protocolo para o preparo da solução de PBS (0,01 M)}

Fosfato de sódio dibásido anidro $\left(\mathrm{Na}_{2} \mathrm{HPO}_{4}\right)($ MERCK) ......................................... 1,09g

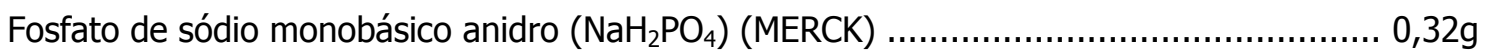

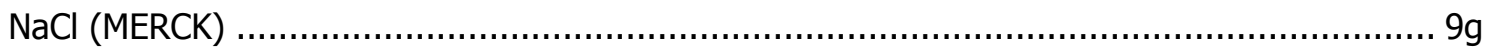

Água destilada ............................................................................... 1000ml

Obs.: Após a dissoluição dos sais, o pH foi corrigido para 7,4 em pHmetro utilizando $\mathrm{NaOH}$ ou $\mathrm{HCl}$ de acordo com o pH obtido na solução acima.

\section{Protocolo para o preparo da solução de citrato de sódio tamponado ( $10 \mathrm{mM}$ )}

Citrato de sódio .......................................................................................... 2,94g

Água destilada .......................................................................... $1000 \mathrm{ml}$

Obs.: A diluição dos sais é realizada sob aquecimento. Após a dissoluição dos sais, o pH foi corrigido para 6,0 em pHmetro utilizando $\mathrm{NaOH}$ ou $\mathrm{HCl}$ de acordo com o pH obtido na solução acima. 
ANEXO 6 - Protocolo para o processamento e inclusão dos fragmentos histológicos em resina Spurr

- Lavagens rápidas em solução tampão cacodilato com 7\% de sacarose

- Pós-fixação em tetróxido de ósmio a $1 \%$ em tampão cacodilato de sódio $0,08 \mathrm{M}, \mathrm{pH} 7,3$ por uma hora

- Lavagem rápida em solução tampão cacodilato

- Coloração 'en bloc'em acetato de uranila a 0,5\%

- Desidratação em banhos de etanol 50\% até $100 \%$

- Dois banhos de 10 minutos cada em óxido de propileno

- Um banho de óxido de propileno com resina SPURR na proporção de 1:1, sob movimento giratório em temperatura ambiente por até 12 horas

- Uma hora em resina SPURR pura em estufa a $60^{\circ} \mathrm{C}$

- Inclusão em resina SPURR pura

- Polimerização em estufa a $60^{\circ} \mathrm{C}$

ANEXO 7 - Protocolo para solução aquosa de Azul de Metileno a 1\% e Azur II a $1 \%$

\section{Solução A}

Azur II $1 \mathrm{~g}$

Água destilada $100 \mathrm{ml}$

\section{Solução B}

Azul de Metileno $1 \mathrm{~g}$

Solução de Bórax a 1\% $100 \mathrm{ml}$

Ácido Clorídrico $2 \mathrm{ml}$

\section{Preparo}

Juntar partes iguais das soluções A e B. 


\section{Referências bibliográficas*}

1. ADAIR, S. M.; WEI, S. H. Y. Supplemental fluoride recommendations for infants based on dietary fluoride intake. Caries Res, v. 12, n. 2., p. 76-82, 1978.

2. ANGMAR-MANSSON, B.; WHITFORD, G. M. Single fluoride doses and enamel fluorosis in the rat. Caries Res, v. 17, p. 172, 1983. /Abstract 45/.

3. ANGMAR-MANSSON, B.; LINDH, V.; WHITFORD, G. M. Enamel and dentin fluoride levels and fluorosis following single fluoride doses: a nuclear micropobe study. Caries Res, v. 24, n. 4, p. 258-62, July/Aug. 1990.

4. AOBA, T. Strategies for improving the assessment of dental fluorosis: focus on chemical and biochemical aspects. Adv Dent Res, v. 8, n. 1, p. 66-74, June 1994.

5. AOBA, T. The effect of fluoride on apatite structure and growth. Crit Rev Oral Biol Med, v. 8, n. 2, p. 136-53, 1997.

6. AOBA, T.; FEJERSKOV, O. Dental fluorosis: chemistry and biology. Crit Rev Oral Biol Med, v. 13, n. 2, p. 155-70, 2002.

7. AOBA, T.; MORENO, E. C.; TANABE, T.; FUKAE, M. Effects of fluoride matrix proteins and their properties in rat secretory enamel. J Dent Res, v. 69, n. 6, p. 1248-55, June 1990. 
8. AOBA, T.; FUKAE, M.; TANABE, T.; SHIMIZU, M.; MORENO, E. C. Selective adsorption of porcine-amelogenins onto hydroxyapatite and their inhibitory activity on hydroxyapatite growth in supersatured solutions. Calcif Tissue Int, v. 41, p. 281-9, Nov. 1987.

9. AOKI, H. Ultrastructural changes induced in rat ameloblasts and enamel by $\mathrm{NaF}$ administration, especially the stages of transition and maturation. Shikwa Gakuho, v. 89, n. 10, p. 1605-37, Oct. 1989.

10. ARANA-CHAVEZ, V. E.; NANCI, A. High-resolution immunocytochemistry of noncollagenous matrix proteins in rat mandibles processed with microwave irradiation. J Histochem Cytochem, v. 49, n. 9, p. 1099-109, Sept. 2001.

11. ARMSTRONG, W. D.; SINGER, L.; MAKOWSKI, E. L. Placental transfer of fluoride and calcium. Am J Obstet Gynecol, v. 107, n. 3, p. 432-4, June 1970.

12. ASSIS, G. F.; BUZALAF, M. A. R.; FARIA, F. A. C..; GRANJEIRO, J. M.; TORRES, S. A.; LARA, V. S.; OLIVEIRA, D. T. Mecanismos biológicos e influência de fatores ambientais na fluorose dentária e a participação do flúor na prevenção da cárie. $\quad$ Rev FOB, v. 7, n. 3/4, p. 63-70, jul./dez. 1999.

13. AVERY, J. K. Agentes que afetam o desenvolvimento dentário e ósseo. In: Desenvolvimento e histologia bucal. 3. ed. Porto Alegre: Artmed, 2005. Cap. 8, p. 156-65.

14.BASFORD, K. E.; PATTERSON, C. M.; KRUGER, B. J. Multivariate analyses of the influence of mottling doses of fluoride on the amino acids of enamel matrix proteins of rat incisors. Arch Oral Biol, v. 21, n. 2, p. 121-9, 1976. 
15. BAWDEN, J. W.; DEATON, T. G.; CRENSHAW, M. A. The short-term uptake and retention of fluoride in developing enamel and bone. J Dent Res, v. 66, n. 10, p. 1687-90, Oct. 1987.

16. BAWDEN, J. W.; DEATON, T. G.; KOCH, G. G.; CRAWFORD, B. P. Effect of an acute maternal fluoride dose on fetal plasma fluoride levels and enamel fluoride uptake in guinea pigs. J Dent Res, v. 68, n. 7, p. 1169-72, July 1989.

17. BAWDEN, J. W.; DEATON, T. G.; KOCH, G. G.; CRAWFORD, B. P. Fluoride uptake in hard tissues of fetal guinea pigs in response to various dose regimens. Arch Oral Biol, v. 37, n. 11, p. 929-33, Nov. 1992.

18. BIRKEDAL-HANSEN, H.; MOORE, W. G.; BODDEN, M. K.; WINDSOR, L. J.; BIRKEDAL-HANSEN, B.; DECARLO, A.; ENGLER, J. A. Matrix metalloproteinases: a review. Crit Rev Oral Biol Med, v. 4, p. 197-250, 1993.

19. BRANDÃO, I. M.; PERES, A. S.; SALIBA, N.A.; MOIMAZ, S. A. Prevalence of dental fluorosis in school children from Marinopolis, São Paulo. Cad Saúde Pública, v. 18, n. 3, p. 877-881, May/June 2002.

20.BRÓGLIO, L. A. Z. Estudo cinético do efeito do flúor sangüíneo e ósseo na incorporação ao esmalte dental de animais (Rattus novergicus var. albinus) previamente expostos ou não e submetidos a uma dose únicas. Piracicaba, 1994. 69p. Tese (Doutorado) - Faculdade de Odontologia de Piracicaba, Universidade estadual de Campinas. 
21.BRZEZINSKI, A.; GEDALIA, I.; DANON, A.; SULMAN, F. G. Fluoride metabolism in pregnant rats. Proc Soc Exp Biol Med, v. 108, p. 342-5, Nov. 1961.

22. BUDIPRAMANA, E. S.; HAPSORO, A.; IRMAWATI, E. S.; KUNTARI, S. Dental fluorosis and caries prevalence in the fluorosis endemic area of Asembagus, Indonesia. Int J Paediatr Dent, v. 12, n. 6, p. 415-422, Nov. 2002.

23. BURT, B. A.; KEELS, M. A.; HELLER, K. E. Fluorosis development in seven age cohorts after an 11-month break in water fluoridation. J Dent Res, v. 82, n. 1, p. 64-68, Jan. 2003.

24. BUTTNER, G.; MUHLER, J. C. Fluoride placental transfer in the rat. J Dent Res, v. 37, n. 2, p. 326-9, Apr. 1958.

25. BUZALAF, M. A.; GRANJEIRO, J. M.; DUARTE, J. L.; TAGA, M. L. Fluoride content of infant foods in Brazil and risk of dental fluorosis. ASDC J Dent Child, v. 69, n. 2, p. 196-200, May/Aug. 2002.

26. CANGUSSU, M. C.; NARVAI, P. C.; CASTELLANOS, F. R.; DJEHIZIAN, V. Dental fluorosis in Brazil: a critical review. Cad Saúde Pública, v. 18, n. 1, p. 7-15, Jan./Fev. 2002.

27. CARVALHO, J. G. Avaliação de várias concentrações de flúor na formação óssea ectópica em ratos jovens e velhos. Bauru, 2005. 83p. Dissertação (Mestrado) - Faculdade de Odontologia de Bauru, Universidade de São Paulo. 
28. CASASCO, A.; CALLIGARO, A.; CASASCO, M. Proliferative and functional stages of rat ameloblast differentiation as revealed by combined immunocytochemistry against enamel matrix proteins and bromodeoxyuridine. Cell Tissue Res, v. 270, n. 3, p. 415-23, Dec. 1992.

29. CHAN, J. T.; QIU, C. C.; WHITFORD, G. M.; WEATHERRED, J. G.; CLARDY, R. K. The distribution of fluoride of prenatal origin in the rat - a pilot study. Arch Oral Biol, v. 34, n. 11, p. 885-8, 1989.

30. CHOUBISA, S. L.; CHOUBISA, L.; CHOUBISA, D. K. Endemic fluorosis in Rajasthan. Indian J Environ Health, v. 43, n. 4, p. 177-189, Oct. 2001.

31. CHOWDHURY, N. G.; BROWN, R. H.; SHEPHERD, M. G. Fluoride intake of infants in New Zealand. J Dent Res, v. 69, n. 12, p. 1828-33, Dec. 1990.

32. COHEN, M. M.; WINER, R. A.; CURBY, W. A. Transport of $F^{18}$ in maternal fetal circulation of the rat. J Dent Res, v. 38, n. 4, p. 673, 1959. /Abstract $59 /$.

33. COSTA, M. R. S. N. Análise morfológica da matriz do esmalte em incisivos de ratos submetidos à fluorose. Bauru, 2000. 118p. Dissertação (Mestrado) - Faculdade de Odontologia de Bauru, Universidade de São Paulo.

34. CRENSHAW, M. A.; BAWDEN, J. W. Fluoride-binding by the organic matrix from early and late developing bovine fetal enamel determined by flow-rate dialysis. Arch Oral Biol, v. 26, n. 6, p. 473-6, 1981. 
35. CRENSHAW, M. A.; WENNBERG, A.; BAWDEN, J. W. Fluoride-binding by the organic matrix of developing bovine enamel. Arch Oral Biol, v. 23, n. 4, p. 285-7, 1978.

36. CURY, J. A. Metabolismo do flúor em função da sua administração a ratas por períodos pré-natais sucessivos. Piracicaba, 1984. 136p. Tese (Livre-docência) - Faculdade de Odontologia de Piracicaba Universidade Estadual de Campinas.

37.DABEKA, R. W.; KARPINSKI, K. F.; MCKENZIE, A. D.; BAJDIK, C. D. Survey of pead, cadmium, and fluoride in human milk and correlation of levels with environmental and food factors. Food Chem Toxicol, v. 24, n. 9, p. 91321, Sept. 1986.

38.DAJEAN, S.; MENANTEAU, J. A western-blotting study of enamel glycoproteins in rat experimental fluorosis. Arch Oral Biol, v. 34, n. 6, p. 413-8, 1989.

39.DEAN, H. T. apud FEJERSKOV, O.; MANJI, F.; BALEUM, V.; MOLLER, I. J. ${ }^{66}$

40. DELESSE, A. apud WEIBEL, E.R. ${ }^{182}$

41.DENBESTEN, P. K. Effects of fluoride on protein secretion and removal during enamel development in the rat. J Dent Res, v. 65, n. 10, p. 1272-7, Oct. 1986.

42. DENBESTEN, P. K. Biological mechanisms of dental fluorosis relevant to the use of fluoride supplements. Community Dent Oral Epidem, v. 27, n. 1., p. 41-7, Feb. 1999. 
43. DENBESTEN, P. K. Mechanism and timing of fluoride effects on developing enamel. J Publ Hith Dent, v. 59, n. 4, p. 247-51, Feb. 1999.

44. DENBESTEN, P. K.; CRENSHAW, M. A. The effects of chronic high fluoride levels on forming enamel in the rat. Arch Oral Biol, v. 29, n. 9, p. 675-9, 1984.

45. DENBESTEN, P. K.; CRENSHAW, M. A. Studies on the changes in developing enamel caused by ingestion of high levels of fluoride in the rat. Adv Dent Res, v. 1, n. 2, p. 176-80, Dec. 1987.

46. DENBESTEN, P. K.; HEFFERNAN, L. M. Enamel proteases in secretory and maturation enamel of rats ingesting 0 and 100ppm fluoride in drinking water. Adv Dent Res, v. 3, n. 2, p. 199-202, Sept. 1989.

47. DENBESTEN, P. K.; THARIANI, H. Biological mechanisms of fluorosis and level and timing of systemic exposure to fluoride with respect to fluorosis. J Dent Res, v. 71, n. 5, p. 1238-1243, May 1992.

48. DENBESTEN, P. K.; CRENSHAW, M. A.; WILSON, M. H. Changes in the fluoride modulation of maturation stage ameloblasts of rats. J Dent Res, v. 64, n. 12, p. 1365-70, Dec. 1985.

49. DENBESTEN, P. K.; HEFFERNAN, L. M.; FEATHERSTONE, D. B.; SHIELDS, C. P. Fluoride binding by matrix proteins in rat mineralizing tissue. Arch Oral Biol, v. 37, n. 6, p. 459-62, 1992. 
50.DENBESTEN; P. K.; YAN, Y.; FEATHERSTONE, J. D. B.; HILTON, J. F.; SMITH, C. E.; LI, W. Effects of fluoride on rat dental enamel matrix proteinases. Arch Oral Biol, v. 47, n. 11, p. 763-70, 2002.

51.DIEKWISCH, T. G. H.; WARE, J.; FINCHAM, A. G.; ZEICHNER-DAVID, M. Immunohistochemical similarities and differences between amelogenin and tuftelin gene products during tooth development. J Histochem Cytochem, v. 45, n. 6, p. 859-66, June 1997.

52.DIRKS, O. B.; JONGELING-EIJNDHOVEN, J. M. P. A.; FLISSEBAALJE, T. D.; GEDALIA, I. Total and free ionic fluoride in human and cow's milk as determined by gas-liquid chromatography and the fluoride electronde. Caries Res, v. 8, n. 2, p. 181-6, 1974.

53. DRINKARD, C. R.; CRENSHAW, M. A.; BAWDEN, J. W. The effect of fluoride on the electrophoretic patterns of developing rat molar enamel. Arch Oral Biol, v. 28, n. 12, p. 1131-4, 1983.

54.DRINKARD, C. R.; DEATON, T. G.; BAWDEN, J. W. Enamel fluoride in nursing rats with mothers drinking water with high fluoride concentrations. J Dent Res, v. 64, n. 6, p. 877-80, June 1985.

55. EKSTRAND, J.; BOREUS, L. O.; DE CHATEAU, P. No evidence of transfer of fluoride from plasma to breast milk. Br Med J, v. 283, n. 6294, p. 761-2, Sept. 1981.

56. EKSTRAND, J.; HARDELL, L. I.; SPAK, C. J. Fluoride balance studies on infants in a 1-ppm-water-fluoride area. Caries Res, v. 18, n. 1, p. 87-92, 1984. 
57.EKSTRAND, J.; SPAK, C. J.; FALCH, J.; AFSETH, J.; ULVESTAD, H. Distribution of fluoride to human breast milk. Caries Res, v. 18, n. 1, p. 93-5, 1984.

58. ERICSSON, Y. The state on fluorine in milk. Acta Odont Scand, v. 16, p. 51-77, 1958.

59. ERICSSON, Y.; HAMMARSTRÖM, L. Mouse placental transfer of $\mathrm{F}^{18}$ in comparison with $\mathrm{Ca}^{45}$. Acta Odont Scand, v. 22, p. 523-38, Nov. 1964.

60.ERICSSON, Y.; ULLBERG, S. Autoradiographic investigations of the distribution of F18 in mice and rats. Acta Odont Scand, v. 16, p. 363-83, 1958.

61. ESALA, S.; VUORI, E. Effects of maternal fluorine intake on breast milk fluorine content. Br J Nutr, v. 4, n. 2, p. 201-4, Sept. 1982.

62. FASSMAN, D. K. Prenatal fluoridation. A literature review. N Y State Dent J, v. 59, n.6, p. 47-51, June/July 1993.

63. FEJERSKOV, O.; JOSEPHSEN, K.; LARSEN, M. J.; THYLSTRUP, A. Cytological features of rat ameloblasts following long-term fluoride exposure. Caries Res, v. 14, p. 181-2, 1980. Special issue. /Abstract 101/.

64. FEJERSKOV, O.; LARSEN, M. J.; JOSEPHSEN, K.; THYLSTRUP, A. Effects of long-term administration of fluoride on plasma fluoride and calcium in relation to forming enamel and dentin in rats. Scand J Dent Res, v. 87, n. 2, p. 98-194, Apr. 1979. 
65. FEJERSKOV, O.; MANJI, F.; BAELUM, V.; MOLLER, I. J. Fluorose

Dentária - um manual para profissionais da saúde. São Paulo: Ed. Santos, 1994.

66. FEJERSKOV; O.; SILVERSTONE, L. M.; MELSON, B.; MOLLER, I. J. Histological features of fluorosed human dental enamel. Caries Res, v. 9, n. 3, p. 190-210, 1975.

67. FELTMAN, R.; KOSEL, G. Prenatal ingestion of fluorides and their transfer to the fetus. Science, v. 122, n. 3169, p. 560-1, Sept. 1955.

68. FELTMAN, R.; KOSEL, G. Prenatal and postnatal ingestion of fluorides fourteen years of investigation - final report. J Dent Med, v. 16, n. 4, p. 190-8, Oct. 1961.

69. FUKAE, M.; TANABE, T.; UCHIDA, T.; LEE, S. K.; RYU, O. H.; MURAKAMI, C.; WAKIDA, K.; SIMMER, J. P.; YAMADA, Y.; BARTLETT, J. D. Enamelysin (matrix metalloproteinase-20): localization in the developing tooth and effects of pH and calcium on amelogenin hydrolises. J Dent Res, v. 77, n. 8, p. 1580-8, Aug. 1998.

70. GARDNER, D. E.; SMITH, F. A.; HODGE, H. C.; OVERTON, D. E.; FELTMAN, R. The fluoride content of placental tissue as related to the fluoride content of drinking water. Science, v. 115, n. 2982, p. 208-9, Feb. 1952.

71. GEDALIA, I.; SHAPIRA, L. Effect or prenatal and postnatal fluoride on the human deciduous dentition. A literature review. Adv Dent Res, v. 3, n. 2, p. 168-76, Sept. 1989. 
72. GEDALIA, I.; ZUKERMAN, H. Fluoride content of teeth and bones of human fetuses: in areas with about 1ppm of fluoride in drinking water. J Am Dent Assoc, v. 71, n. 5, p. 1121-3, Nov. 1965.

73. GEDALIA, I.; BRZEZINSKI, A.; BERCOVICI, B.; LAZAROV, E. Placental transfer of fluorine in the human fetus. Proc Soc Exp Biol Med, v. 106, p. 147-9, Jan. 1961.

74. GEDALIA, I.; BRZEZINSKI, A.; ZUKERMAN, H.; MAYERSDORF, A. Placental transfer of fluoride in human fetus at low and high F-intake. J Dent Res, v. 43, n. 5, p. 669-71, Sept./Oct. 1964.

75. GERLACH, R. F.; SOUZA, A. P.; CURY, J. A.; LINE, S. R. P. Fluoride effects on the activity of enamel matrix proteinases in vitro. Eur J Oral Sci, v. 108, n. 1, p. 48-53, Feb. 2000.

76. GLENN, F. B.; GLENN, W. D.; BURDI, A. R. Prenatal fluoride for growth and development: part X. J Dent Children, v. 64, n. 5, p. 317-21, Sept./Oct. 1997.

77. HEFFERNAN, L. M.; DENBESTEN, P. K. Fluoride binding in secretory and maturation rat enamel. J Dent Res, v. 70, p. 309, 1991. /Abstract 348/.

78. HOLLAND, R. I.; HONGSLO, J. K. The effect of fluoride on the cellular uptake and pool of aminoacids. Acta Pharmacol Toxicol, v. 44, p. 354-8, 1979.

79. HOROWITZ, H. S. Fluoride and enamel defects. Adv Dent Res, v. 3, n. 2, p. 143-6, Sept. 1989. 
80. HOSSNY, E.; REDA, S.; MARZOUK, S.; DIAB, D.; FAHMY, H. Serum fluoride levels in a group of egyptian infants and children from Cairo city. Arch Environ Health, v. 58, n. 5, p. 306-15, May 2003.

81. INAGE, T.; SHIMOKAWA, H.; WAKAO, K.; SASAKI, S. Gene expression and localization of amelogenin in the rat incisor. Adv Dent Res, v. 10, n. 2, p. 201-7, Nov. 1996.

82. INAGE, T.; SHIMOKAWA, H.; TERANISHI, Y.; IWASE, T.; TODA, Y.; MORO, I. Immunocytochemical demonstration of amelogenins and enamelins secreted by ameloblasts during the secretory and maturation stages. Arch Histol Cytol, v. 52, n. 3, p. 213-29, July 1989.

83. INAGE, T.; YOSHIDA, T.; HORI, Y.; HATAKEYAMA, H.; FUJITA, M.; KAJIYAMA, N.; KADO, K.; NAGAI, K. The distribution of multinucleate ameloblasts in a rat upper incisor. J Nihon Univ Sch Dent, v. 28, n. 1, p. 1-11, Mar. 1986.

84. INAI, T.; NAGATA, K.; KUKITA, T.; KURISU, K. Demonstration of amelogenin in the enamel-free cusps of rat molar tooth germs: immunofluorescent and immunoelectron microscopic studies. Anat Rec, v. 233, n. 4, p. 588-96, Aug. 1992.

85. INAI, T.; KUKITA, T.; OHSAKI, Y.; NAGATA, K.; KUKITA, A.; KURISU, K. Immunohistochemical demonstration of amelogenin penetration toward the dental pulp in the early stages of ameloblast development in rat molar tooth germs. Anat Rec, v. 229, n. 2, p. 259-70, Feb. 1991.

86. JACKSON, R. D.; BRIZENDINE, E. J.; KELLY, S. A.; HINESLEY, R.; STOOKEY, G. K.; DUNIPACE, A. J. The fluoride content of foods and beverages from 
negligibly and optimally fluoridated communities. Community Dent Oral Epidemiol, v. 30, n. 5, p. 382-91, Oct. 2002.

87. JOSEPHSEN, K.; FEJERSKOV, O. Ameloblast modulation in the maturation zone of the rat incisor enamel organ. A light and electron microscopy study. J Anat (Lond), v. 124, n. 1, p. 45-70, Sept. 1977.

88. KALLENBACH, E. Fine structure of rat incisor ameloblasts in transition between enamel secretion and maturation stages. Tissue Cell, v. 6, n. 1, p. 173-90, 1974.

89. KARG, H. A.; BURGER, E. H.; LYARUU, D. M.; WÖLTGENS, J. H.; BRONCKERS, A. L. Gene expression and immunolocalization of amelogenins in developing embryonic and neonatal hamster teeth. Cell Tissue Res, v. 288, n. 3, p. 545-55, June 1997.

90.KATO, K.; NAKAGAKI, H.; SAKAKIBARA, Y.; KAMEYAMA, Y.; WEATHERELL, J. A.; ROBINSON, C. Distribution of fluoride in the enamel of rat incisors examined by an abrasive microsampling technique Arch Oral Biol, v. 33, n. 9, p. 653-6, 1988.

91.KATZ, S.; STOOKEY, G. K. Further studies concerning the placental transfer of fluoride in the rat. J Dent Res, v. 52, n. 2, p. 206-10, Mar./Apr. 1973.

92. KOPARAL, E.; ERTUGRUL, F.; OZTEKIN, K. Fluoride levels in breast milk and infant foods. J Clin Pediatr Dent, v. 24, n. 4, p. 299-302, Summer 2000. 
93. KRUGER, B. J. Histological effects of fluoride and molybdenum on developing dental tissues. Aust Dent J, v. 12, p. 54-60, Feb. 1967.

94. KRUGER, B. J. Ultrastructural changes in ameloblasts from fluoride treated rats. Arch Oral Biol, v. 13, n. 8., p. 969-77, Aug. 1968.

95. KRUGER, B. J. An autoradiographic assessment of the effect of fluoride on the uptake of $\left[{ }^{3} \mathrm{H}\right]$ proline by ameloblasts in the rat. Arch Oral Biol, v. 15, n. 2, p. 103-8, Feb. 1970.

96. KRUGER, B. J. The effect of different levels of fluoride on the ultrastructure of ameloblasts in rat. Arch Oral Biol, v. 15, n. 2, p. 109-14, Feb. 1970.

97. KRUGER, B. J. Utilization of $\left[{ }^{3} \mathrm{H}\right]$ serine by ameloblasts of rats receiving sub-mottling doses of fluoride. Arch Oral Biol, v. 17, n. 10, p. 1389-94, Oct. 1972.

98. KUBOTA, K.; LEE, D. H.; TSUCHIYA, M.; YOUNG, C. S.; EVERETTI, E. T.; MARTINEZ-MIER, E. A.; SNEAD, M. L.; NGUYEN, L.; URANO, F.; BARTLETT, J. D. Fluoride induces endoplasmic reticulum stress in ameloblasts responsible for dental enamel formation. J Biol Chem, v. 280, n. 24, p. 23194-202, June 2005.

99. LANGE, A.; HAMMARSTRÖM, L. Cell sizes and apposition of dental hard tissues in rats. Acta Odontol Scand, v. 42, n. 4, p. 215-23, Aug. 1984.

100. LARSEN, M. J.; RICHARDS, A.; FEJERSKOV, O. Effect of intraperitoneally injected fluoride on plasma calcium in suckling and adult rats. Calcif Tissue I nt, v. 33, n. 5, p. 541-4, 1981. 
101. LATIFAH, R.; RAZAK, I. A. Fluoride leves in mother's milk. J Pedod, v. 13, n. 2, p. 149-54, Winter 1989.

102. LI, W.; MACHULE, D.; GAO, C.; DENBESTEN, P. K. Activation of recombinant bovine matrix metalloproteinase-20 and its hydrolysis of two amelogenin oligopeptides. Eur J Oral Sci, v. 107, n. 5, p. 352-9, Oct. 1999.

103. LI, Y.; DECKER, S.; YUAN, Z. A.; DENBESTEN, P. K.; ARAGON, M. A.; JORDAN-SCIUTTO, K.; ABRAMS, W. R.; HUH, J.; MCDONALD, C.; CHEN, E.; MACDOUGALL, M.; GIBSON, C. W. Effects of sodium fluoride on the actin cytoskeleton of murine ameloblast. Arch Oral Biol, v.50, n. 8, p. 681-8, Aug. 2005.

104. LIMA, Y. B.; CURY, J. A. Fluoride intake by children from water and dentifrice. Rev Saúde Pública, v. 35, n. 6, p. 576-581, Dec. 2001.

105. LIMEBACK, H. Enamel formation and the effects of fluoride. Community Dent Oral Epidemiol, v. 22, n. 3, p. 144-7, June 1994.

106. LOUW, A. J.; VAN WYK, P. J. Placental transfer of fluoride. J Dent Assoc S Afr, v. 39, n. 2, p. 61-2, Feb. 1984.

107. LYARUU, D. M.; JONG, M.; BRONCKERS, A. L. J. J.; WOLTGENS, J. H. M. Ultrastructural study of fluoride-induced in vitro hypermineralization of enamel in hamster tooth germs explanted during the secretory phase of amelogenesis. Arch Oral Biol, v. 31, n. 2, p. 109-17, 1986. 
108. MACIEJEWSKA, I; ADAMOWICZ-KLEPALSKA. B. Influence of low and high doses of fluoride on tooth germ development in rats. Folia Morphol (Warsz), v. 59, n. 4, p. 307-10, 2000.

109. MACIEJEWSKA, I.; ADAMOWICZ-KLEPALSKA, B.; KMIEC, Z.; DZIEWIATKOWSKI, J. Influence of diet and fluoride on dentin and enamel deposition and maturation in rats. Folia Morphol (Warsz), v. 59, n. 2, p. 131-6, 2000.

110. MAPLESDEN, D. C.; MOTZOK, I.; OLIVER, W. T.; BRANION, H. D. Placental transfer of fluorine to the fetus in rats and rabbits. J Nutr, v. 71, p. 70-7, May 1960.

111. MATSUO, S.; KIYOMIYA, K.; KUREBE, M. Mechanism of toxic action of fluoride in dental fluorosis: whether trimeric $G$ proteins participate in the disturbance of intracellular transport of secretory ameloblast exposed to fluoride. Arch Toxicol, v. 72, n. 12, p. 798-806, Dec. 1998.

112. MATSUO, S.; INAI, T.; KURISU, K.; KIYOMIYA, K.; KUREBE, M. Influence of fluoride on secretory pathway of the secretory ameloblast in rat incisor tooth germs exposed to sodium fluoride. Arch Toxicol, v. 70, n. 7, p. 420-9, 1996.

113. MENEZES, L. M.; SOUSA, L.; RODRIGUES, L. K., CURY, J.A. Selfperception of fluorosis due to fluoride exposure to drinking water and dentifrice. Rev Saúde Pública, v. 36, n. 6, p. 752-4, Dec. 2002.

114. MONSOUR, P. A.; HARBROW, D. J.; WARSHAWSKY, H. Effects of acute doses of sodium fluoride on the morphology and the detectable calcium 
associated with secretory ameloblasts in rat incisors. J Histochem Cytochem, v. 37, n. 4, p. 463-71, Apr. 1989.

115. MONSOUR, P. A.; KRUGER, B. J.; SMID, J. R. Effects of a single intravenous dose of sodium fluoride on plasma electrolytes and metabolites in rats, rabbits and cockerels. J Dent Res, v. 64, n. 11, p. 1281-5, Nov. 1985.

116. MONTHERRAT-CARRET, L.; PERRAT-MABILON, B.; BARBEY, E.; BOULOC, R.; BOIVIN, G.; MICHELET, A.; MAGLOIRE, H. Chemical and x-ray analysis of fluoride, phosphorus, and calcium in human foetal blood and hard tissues. Arch Oral Biol, v. 41, n. 12, p. 1169-78, Dec. 1996.

117. MÖRNSTAD, H.; HAMMARSTRÖM, L. Morphological changes in the rat enamel organ following a single intraperitoneal injection of sodium fluoride. Scand J Dent Res, v. 86, n. 4, p. 211-20, July 1978.

118. NANCI, A.; KAWAGUCHI, H.; KOGAWA, Y. Ultrastructural studies and immunolocalization of enamel proteins in rodent secretory stage ameloblasts processed by various cryofixation methods. Anat Rec, v. 238, n. 4, p. 42536, Apr. 1994.

119. NANCI, A.; SLAVKIN, H. C.; SMITH, C. E. Application of high-resolution immunocytochemistry to the study of the secretory, resorptive and degradative functions of ameloblasts. Adv Dent Res, v. 1, n. 2, p. 148-61, Dec. 1987.

120. NANCI, A.; SLAVKIN, H. C.; SMITH, C. E. Immunocytochemical and radioautographic evidence for secretion and intracellular degradation of 
enamel proteins by ameloblasts during the maturation stage of amelogenesis in rat incisors. Anat Rec, v. 217, n. 2, p. 107-23, Feb. 1987.

121. NANCI, A.; HASHIMOTO, J.; ZALZAL, S.; SMITH, C. E. Transient accumulation of proteins at interred and rod enamel growth sites. Adv Dent Res, v. 10, n. 2, p. 135-49, Nov. 1996.

122. NANCI, A.; ZALZAL, S.; LAVOIE, P.; KUNIKATA, M.; CHEN, W.; KREBSBACH, P. H.; YAMADA, Y.; HAMMARSTRÖM, L.; SIMMER, J. P.; FINCHAM, A. G.; SNEAD, M. L.; SMITH, C. E. Comparative immunohistochemical analyses of the developmental expression and distribution of ameloblastin and amelogenin in rat incisors. J Histochem Cytochem, v. 46, n. 8, p. 911-34, Aug. 1998.

123. NEIMAN, A.; EISENMANN, D. The effect of strontium, cobalt and fluoride on rat incisor enamel formation. Anat Rec, v. 183, n. 2, p. 303-22, Oct. 1975.

124. NISHIKAWA, S.; JOSEPHEN, K. Cyclic localization of actin its relationship to junctional complexes in maturation ameloblasts of the rat incisor. Anat Rec, v. 219, n. 1, p. 21-31, Sept. 1987.

125. NORDLUND, A. L.; LINDSKOG, S. Immunoglobulin G in cystic lesions of rat enamel organ following fluoride intoxication. Scand J Dent Res, v. 94, n. 1, p. 15-8, 1986.

126. NORDLUND, A. L.; EKSTRAND, J. L.; HAMMARSTRÖM, L. Fluorideinduced cysts changes in the enamel organ of the rat molar. J Oral Pathol, v. 15, n. 2, p. 87-92, Feb. 1986. 
127. NORDLUND, A. L.; SIMMELINK, J. W.; HENELL, F.; HAMMARSTRÖM, L. Ultrastructure of fluoride-induced cysts in the rat molar enamel organs. Scand J Dent Res, v. 94, n. 4, p. 327-37, Aug. 1986.

128. OLIVEIRA, D. T. Efeito crônico do flúor no esmalte e nos ameloblastos secretores de incisivos de ratos. Piracicaba, 1988. 47p. Dissertação (Mestrado). Faculdade de Odontologia de Piracicaba Universidade Estadual de Campinas.

129. ORSINI, G.; LAVOIE, P.; SMITH, C. E.; NANCI, A. Immunochemical characterization of a chicken egg yolk antibody to secretory forms of rat incisor amelogenin. J Histochem Cytochem, v. 49, n. 3, p. 285-92, Mar. 2001.

130. OVERALL, C. M.; LIMEBACK, H. Identification and characterization of enamel proteinases isolated from developing enamel. Biochem J, v. 256, n. 3, p. 656-72, Dec. 1988.

131. PARDINI, L. C.; TAGA, R. Stereological study of the sexual dimorphism in mouse submandibular glands. Okajimas Folia Anat J pn, v. 73, n. 2-3, p. 19-24, Aug. 1996.

132. PARKER, P. R.; BAWDEN, J. W. Prenatal fluoride exposure: measurement of plasma levels and enamel uptake in the guinea pig. J Dent Res, v. 65, n. 11, p. 1341-5, Nov. 1986.

133. PATTERSON, C. M.; BASFORD, K. E.; KRUGER, B. J. The effect of fluoride on the immature enamel matrix protein of the rat. Arch Oral Biol, v. 21 , n. 2, p. 131-2, 1976. 
134. PERGOLIZZI, S.; SANTORO, A.; SANTORO, G.; TRIMARCHI, F.; ANASTASO, G. Enamel fluorosis in rat's incisor: S.E.M. and T.E.M. investigation. Bull Group I nt Rech Sci Stomatol Odontol, v. 38, n. 3-4, p. 95-105, Sept./Oct. 1995.

135. PINDBORG, J. J.; WEINMANN, J. P. Morphologic and functional correlations in the enamel organ of the rat incisor during amelogenesis. Acta Anat, v. 36, n. 4, p. 367-81, 1969.

136. POULSEN, S.; LARSEN, M. J.; LARSON, R. H. Effect of fluoridated milk and water on enamel fluoride content and dental caries in the rat. Caries Res, v. 10, n. 3, p. 227-33, 1976.

137. RAHUL, P.; HEDGE, A. M.; MUNSHI, A. K. Estimation of the fluoride concentrations in human breast milk, cow's milk and infant formulae. Clin Pediatr Dent, v. 27, n. 3, p. 257-60, 2003.

138. REITH, E. J. The ultrastructure of ameloblasts during matrix formation and the maturation of enamel. J Biophys Biochem Cytol, v. 9, p. 825-39, Apr. 1961.

139. RIBEIRO, D. A. Estudo morfológico e estereológico ultraestrutural do ameloblasto na fase de maturação do esmalte de dentes incisivos de ratos submetidos à fluorose. Bauru, 2001. 137p. Dissertação (Mestrado) - Faculdade de Odontologia de Bauru, Universidade de São Paulo. 
140. RIBEIRO, D. A.; ASSIS, G. F.; HIROTA, L. Morphologic and stereologic ultrasctructural study of secretory ameloblast in rat incisors submitted to fluorosis. J Dent Res, v. 80, n. 5, p. 617, 2001. /Abstract 0725/.

141. RICHARDS, A. Nature and mechanisms of dental fluorosis in animals. J Dent Res, v. 69, p. 701-5, Feb. 1990. Special issue.

142. ROBINSON, C.; KIRKHAM, J. The effect of fluoride on the developing mineralized tissues. J Dent Res, v. 69, p. 685-691, Feb. 1990. Special issue.

143. ROBINSON, C.; BRIGGS, H. D.; ATKINSON, P. J. Histology of enamel organ and chemical composition of adjacent enamel in rat incisors. Calcif Tissue I nt, v. 33, n. 5, p. 513-20, 1981.

144. ROBINSON, C.; KIRKHAM, J.; HALLSWORTH, A. S. Volume distribution and concentration of protein, mineral and water in developing bovine enamel. Arch Oral Biol, v. 33, n. 3, p. 159-62, 1988.

145. ROBINSON, C.; BRIGGS, H. D.; ATKINSON, P. J.; WEATHERELL, J. A. Matrix and mineral changes in developing enamel. J Dent Res, v. 58, p. 871-80, Mar 1979. Special issue B.

146. SALAMA, A. H.; ZAKI, A. E.; EISENMANN, D. R. Fine structural changes and lysosomal phosphatase cytochemistry of ameloblasts associated with the transitional stage of enamel formation in the rat incisor. Am J Anat, v. 190, n. 3, p. 279-90, Mar. 1991. 
147. SASAKI, T. Morphology and function of maturation ameloblasts in kitten tooth germs. J Anat, v. 138, n. 2, p. 333-42, Mar. 1984.

148. SASAKI, T.; TAKAGI, M.; YANAGISAWA, T. Structure and function of secretory ameloblasts in enamel formation. Ciba Found Symp, v. 205, p. 32-46, 1997.

149. SASAKI, T.; HIGASHI, S.; TACHIKAWA, T.; YOSHIKI, S. Thin-section, tracer, and freeze-fracture study of the smooth-ended maturation ameloblasts in rat incisors. Acta Anat (Basel), v. 117, n. 4, p. 303-13, 1983.

150. SCHOUR, I.; MASSLER, M. The teeth. In: FARRIS, E. J.; GRIFFTH, Junior, J. Q. The rat in laboratory investigation. Philadelphia, Lippincott, 1949, p. 104-65.

151. SHINODA, H. Effect of long-term administration of fluoride on physicochemical properties of the rat incisor enamel. Calcif Tissue Res, v. 18, n. 2, p. 91-100, July 1975.

152. SHORE, R. C.; ROBINSON, C.; KIRKHAM, J.; HEROLD, R. C. An immunohistochemical study of the effects of fluoride on enamel development in the rat incisor. Arch Oral Biol, v. 38, n. 7, p. 607-10, July 1993.

153. SILVA-SOUSA, Y. T. C.; PERES, L. C.; VANSAN, L. P.; FOSS, M. C. Are there structural alterations in the enamel organ of offspring of rats with alloxan-induced diabetes mellitus? Braz Dent J, v. 14, n. 3, p. 162-7, 2003. 
154. SIMMELINK, J. W.; LANGE, A. Ultrastructure of altered rat enamel beneath fluoride-induced cysts. J Oral Pathol, v. 15, n. 3, p. 155-61, Mar. 1986.

155. SIMMER, J. P. Alternative splicing of amelogenins. Connect Tissue Res, v. 32, n. 1-4, p. 131-6, 1995.

156. SIMMER, J. P.; HU, J. C. C. Expression, structure, and function of enamel proteinases. Connect Tissue Res, v. 43, n. 2-3, p. 441-9, 2002.

157. SIMMER, J. P.; HU, C. C.; LAU, E. C.; SARTE, P.; SLAVKIN, H. C.; FINCHAM, A. G. Alternative splicing of the mouse amelogenin primary RNA transcript. Calcif Tissue I nt, v. 55, n. 4, p. 302-10, Oct. 1994.

158. SIMMER, J. P.; LAU, E. C.; HU, C. C.; AOBA, T.; LACEY, M.; NELSON, D. Isolation and characterization of a mouse amelogenin expressed in Escherichia coli. Calcif Tissue I nt, v. 54, n. 4, p. 312-9, Apr. 1994.

159. SIMPSON, W. J.; TUBA, J. An investigation of fluoride concentration in the milk of nursing mothers. J Oral Med, v. 23, n. 3, p. 104-6, July 1968.

160. SMID, J. R.; MONSOUR, P. A.; HARBROW, D. J.; YOUNG, W. G. A histochemical study of the effects of high doses of sodium fluoride on dipeptidyl peptidase II activity in the rat incisor ameloblast. Arch Oral Biol, v. 35, n. 8, p. 671-5, 1990.

161. SMITH, C. E.; NANCI, A. A method for sampling the stages of amelogenesis on mandibular rat incisors using the molars as a reference for dissection. Anat Rec, v. 225, n. 3, p. 257-66, Nov. 1989. 
162. SMITH, C. E.; NANCI, A. Secretory activity as a function of the development and maturation of ameloblasts. Connect Tissue Res, v. 22, n. 1-4, p. 147-56, 1989.

163. SMITH, C. E.; NANCI, A. Protein dynamics of amelogenesis. Anat Rec, v. 245, n. 2, p. 186-207, June 1996.

164. SMITH, C. E.; NANCI, A.; DENBESTEN, P. K. Effects of chronic fluoride exposure on morphometric parameters defining the stages of amelogenesis and ameloblast modulation in rat incisors. Anat Rec, v. 237, n. 2, p. 243258, Oct. 1993.

165. SMITH, C. E.; POMPURA J. R.; BORENSTEIN, S.; FAZEL, A.; NANCI, A. Degradation and loss of matrix proteins from developing enamel. Anat Rec, v. 224, n. 2, p. 292-316, June 1989.

166. SPAK, C. J.; EKSTRAND, J.; HARDELL, L. I. Fluoride in human breast milk. Caries Res, v. 17, n. 2, p. 161, 1983. /Abstract 14/.

167. SPEIRS, R. L. Fluoride incorporation into developing enamel of permanent teeth in the domestic pig. Arch Oral Biol, v. 20, n. 12, p. 87783, Dec. 1975.

168. SPEIRS, R. L. Incorporation of dietary fluoride supplement into bone and developing teeth of the domestic pig. Arch Oral Biol, v. 23, n. 11, p. 1013-7, 1978.

169. TABATA, M. J.; MATSUMURA, T.; LIU, J.; WAKISAKA, S.; KURISU, K. Expression of cytokeratin 14 in ameloblast-lineage cells of the developing 
tooth of rat, both in vivo and in vitro. Arch Oral Biol, v. 41, n. 11, p. 1019-27, Nov. 1996.

170. TAN, J.; LEUNG, W.; MORADIAN-OLDAK, J.; ZEICHNER-DAVID, M.; FINCHAM, A.G. Quantitative analysis of amelogenin solubility. J Dent Res, v. 77, n. 6, p. 1388-96, June 1998.

171. TANABE, T.; AOBA, T.; MORENO, E. C.; FUKAE, M. Effect of fluoride in apatite lattice on adsorption of enamel proteins onto calcium apatites. J Dent Res, v. 67, n. 3, p. 536-42, Mar. 1988.

172. TEN CATE, A. R. Amelogênese. In: Histologia bucal: desenvolvimento, estrutura e função. 5. ed. Rio de Janeiro: Editora Guanabara Koogan, 2001. Cap. 10, p. 186-204.

173. THARIANI, H.; McKEE, M. D.; DENBESTEN, P. K. Fluoride effect on the rate of modulation of maturation stage ameloblasts. J Dent Res, v. 70, p. 370, 1991. /Abstract 837/.

174. THEUER, R. C.; MAHONEY, A. W.; SARETT, H. P. Placental transfer of fluoride and tin in rats given various fluoride and tin salts. J Nutr, v. 101, n. 4, p. 525-32, Apr. 1971.

175. THYLSTRUP, A. Is there a biological rationale for prenatal fluoride administration. J Dent Child, v. 48, n. 2, p. 103-8, Mar./Apr. 1981.

176. TOYAMA, Y.; NAKAGAKI, H.; KATO, S.; HUANG, S.; MIZUTANI, Y.; KOJIMA, S.; TOYAMA, A.; OHNO, N.; TSUCHIYA, T.; KIRKHAM, J.; ROBINSON, C. Fluoride concentrations at and near the neonatal line in 
human deciduous tooth enamel obtained from a naturally fluoridated and a non-fluoridated area. Arch Oral Biol, v. 46, n. 2, p. 147-53, Feb. 2001.

177. VILLA, A.; GUERRERO, S.; CISTERNAS, P.; MONCKEBERG, F. Fluoride bioavailability from disodium monofluorophosphate fluoridated milk in children and rats. Caries Res, v. 23, n. 3, p. 179-83, 1989.

178. WALTON, R. E.; EISENMANN, D. R. Ultrastructural examination of various stages of amelogenesis in the rat following parenteral fluoride administration. Arch Oral Biol, v. 19, n. 2, p. 171-82, Feb. 1974.

179. WARSHAWSKY, H.; MOORE, G. A techinique for the fixation and descalcification of rat incisors for electron microscopy. J Histochem Cytochem, v. 15, n. 9, p. 542-9, Sept. 1967.

180. WEATHERELL, J. A.; DEUTSCH, D.; ROBINSON, C.; HALLSWORTH, A. S. Fluoride concentrations in developing enamel. Nature, v. 256, n. 5514, p. 230-2, July 1975.

181. WEDDLE, D. A.; MUHLER, J. C. Metabolism of small concentrations of fluorine in the albino rat. J Dent Res, v. 34, n. 6, p. 900-9, Dec. 1955.

182. WEIBEL, E. R. Stereological principles of morphometry in electron microscopy cytology. I Int Rev Cytol, v. 26, p. 235-302, 1969.

183. WHITFORD, G. M. Effects of plasma fluoride and dietary calcium concentrations on GI absorption and secretion of fluoride in the rat. Calcif Tissue I nt, v. 54, n. 5, p. 421-5, May 1994. 
184. YAMAMOTO, H.; SASAKI, J.; MATSUUMA, J.; NOMURA, T.; SATO, E. F.; SHIMOKAWA, H.; ISHIZEKI, K.; NAWA, T. Characterization of the inner enamel epitelium in the enamel-free area based on the ability to secrete enamel protein demonstrated by in situ hybridizidation and immunohistochemistry. Acta Anat (Basel), v. 160, n. 4, p. 232-8, 1997.

185. ZHOU, R.; ZAKI, A. E.; EISENMANN, D. R. Morphometry and autoradiographiy of altered rat enamel protein processing due to chronic exposure to fluoride. Arch Oral Biol, v. 41, n. 8/9, p. 739-47, Aug. 1996.

186. ZIPKIN, I.; BABEAUX, W. L. Maternal transfer of fluoride. J Oral Ther Pharmacol, v. 1, n. 6, p. 652-65, May 1965. 
Abstract 
Abstract

198 


\section{ABSTRACT \\ Morphological ultrastructural and immunohistochemical study of the fluorine excess influence on rat incisor tooth germ development}

The dental fluorosis is a result of fluorine toxicity during odontogenesis. Several experimental models have been used in attempt to explain the fluorine pathogenesis in enamel, but during the fetal or the initial postnatal period, there is not much information about its action. For this reason, in this research, the female rats received 0,7 or $100 \mathrm{ppm}$ of sodium fluoride in drinking water, one week before matching, during all gestation ( 21 days) and nursing phases. The hemimandibles of the pups at the age of 0,7 and 14 days of postnatal life $(n=6)$ were collected for the morphologic study in optical and electronic microscopy, immunohistochemistrical analysis for the amelogenin and morphometric study of the enamel matrix and of ameloblasts in the secretion and maturation phases of the lower incisive. The results showed a reduction of the enamel matrix secretion, disorganization of the mitochondrial crests, large vacuoles in the apical portion of the cytoplasm, retention of the intracisternal material and dilatation of some cisterns in rough endoplasmic reticulum for the secretory ameloblasts of $100 \mathrm{ppm}$ experimental group in all experimental periods. In the groups of animals at the age of 7 and 14 days, a reduction $(p<0.05)$ in the cytoplasmic volume of $23.80 \%$ and $24.75 \%$, respectively, was observed in relation to the control groups. In smoothed-border maturation ameloblasts, there was a great amount of vacuoles with endocited electrondense matrix, suggesting a retard in the reabsorption process. In ruffled-border ameloblasts, there were some dilated mitochondrias. The immunohistochemistrical analysis showed no difference in intensity and marking pattern of the enamel matrix in any of the studied groups. Therefore, part of the excessive dose of sodium fluoride given to the mother in drinking water can reach the pup by the placenta and by the mother's milk, causing morphological alterations in ameloblasts and suggesting a reduction in the secretion and a retard in the matrix reabsorption. 